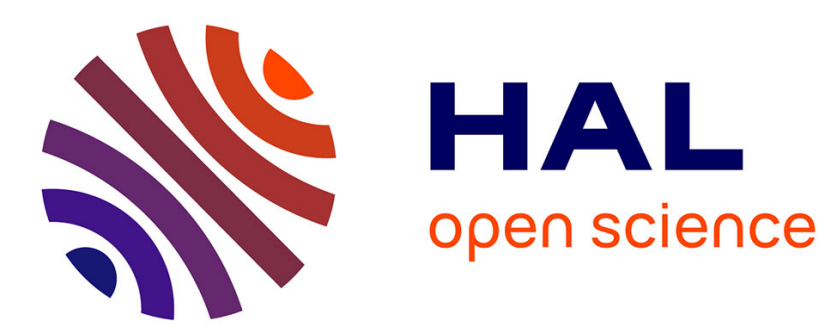

\title{
Intramolecular d10-d10 interactions in heterometallic clusters of the transition metals
}

Sabrina Sculfort, Pierre Braunstein

\section{To cite this version:}

Sabrina Sculfort, Pierre Braunstein. Intramolecular d10-d10 interactions in heterometallic clusters of the transition metals. Chemical Society Reviews, 2011, 40 (5), pp.2741-2760. 10.1039/c0cs00102c . hal-01872459

\section{HAL Id: hal-01872459 \\ https://hal.science/hal-01872459}

Submitted on 20 Sep 2018

HAL is a multi-disciplinary open access archive for the deposit and dissemination of scientific research documents, whether they are published or not. The documents may come from teaching and research institutions in France or abroad, or from public or private research centers.
L'archive ouverte pluridisciplinaire HAL, est destinée au dépôt et à la diffusion de documents scientifiques de niveau recherche, publiés ou non, émanant des établissements d'enseignement et de recherche français ou étrangers, des laboratoires publics ou privés. 


\section{Revised CS-CRV-09-2010-000102}

\section{Intramolecular $\mathrm{d}^{10}-\mathrm{d}^{10}$ interactions in Heterometallic Clusters of} the Transition Metals ${ }^{\dagger}$

Sabrina Sculfort and Pierre Braunstein*

Laboratoire de Chimie de Coordination, Institut de Chimie (UMR 7177 CNRS), Université de Strasbourg, 4 rue Blaise Pascal - CS 90032, F-67081 Strasbourg Cedex, France.

E-mail: braunstein@unistra.fr

Fax: +33 368851 322; Tel: +33368 851308 .

${ }^{\dagger}$ In memoriam Dr. Marie-Madeleine Rohmer 


\section{For the Table of Contents}

This review deals with the synthesis and structures of heterometallic transition metal clusters displaying intramolecular, metallophilic $\mathrm{d}^{10}-\mathrm{d}^{10}$ interactions.

INTRAmolecular Interactions between Closed-Shell Ions: Attractive $\mathrm{d}^{10}{ }_{-} \mathrm{d}^{10}$ Interactions as Shape- and Property-Directing Factors;

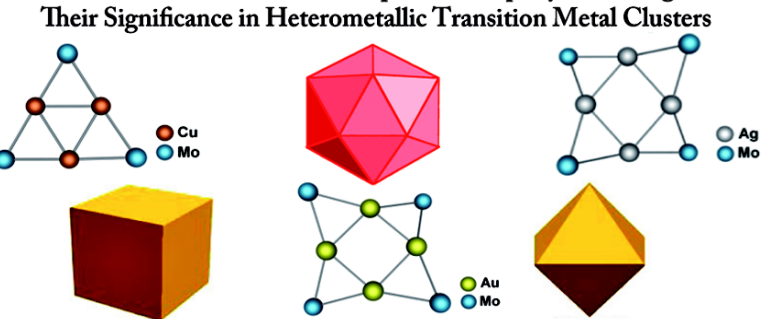




\begin{abstract}
Weak attractive interactions between closed shell metal ions have been increasingly studied in the last few years and are generally designated as metallophilic interactions. They are best evidenced in the solid state where structural data obtained by X-ray diffraction provide precise information about the distance between the metals involved. The strength of such metal-metal interactions has been compared to that of hydrogen bonding (ca. 7-11 kcal/mol) and is clearly sufficient to bring about novel bonding and structural features and confer interesting physical properties such as luminescence, polychromism, magnetism or onedimensional electrical conductivity. The $\mathrm{Cu}(\mathrm{I})-\mathrm{Cu}(\mathrm{I}), \operatorname{Ag}(\mathrm{I})-\mathrm{Ag}(\mathrm{I})$ and $\mathrm{Au}(\mathrm{I})-\mathrm{Au}(\mathrm{I})$ interactions have been increasingly observed and the latter have certainly been the most studied. Early qualitative analyses of the aurophilic attraction focused on Au-Au bonding originating from $6 \mathrm{~s}, 6 \mathrm{p}$ and $5 \mathrm{~d}$ orbital mixing. Numerous theoretical studies on metallophilic interactions continue to be carried out at various levels of sophistication which take into account relativistic and correlation effects to describe these van der Waals-type interactions. In this review, we would like to focus on the synthesis and structures of heterometallic clusters of the transition metals in which intra- rather than intermolecular $\mathrm{d}^{10}-\mathrm{d}^{10}$ interactions are at work, in order to limit the role of packing effects. We wish to provide the reader with a comparative overview of the metal core structures resulting from or favoring metallophilic interactions but do not intend to provide a comprehensive coverage of the literature. We will first examine heterometallic clusters displaying homometallic and then heterometallic $\mathrm{d}^{10}-\mathrm{d}^{10}$ interactions. Although the focus of this review is on $\mathrm{d}^{10}-\mathrm{d}^{10}$ interactions involving metals from the group 11, we shall also briefly examine for comparison some complexes displaying intramolecular $\mathrm{d}^{10}-\mathrm{d}^{10}$ interactions involving metals from other groups.
\end{abstract}

\title{
1. Introduction
}

Whereas organometallic chemistry primarily focuses on compounds with metal-carbon bonds, coordination chemistry is concerned with all aspects of the interactions between ligands and metals, and includes the study of the synthesis, physical and chemical properties of the resulting metal complexes. Optimizing their synthesis and understanding their electronic structures, the nature of the bonding between metals and ligands and their reactivity are essential to this chemistry. Recognizing that direct bonding between metal atoms could exist in molecules - and not only in the bulk state - was the start of a "postWernerien" chemistry. Cotton coined the term «metal atom cluster » in 1964: "The term 
cluster seems an appropriate one for a finite group of metal atoms which are held together mainly, or at least to a significant extent, by bonds directly between the metal atoms, even though some nonmetal atoms may also be intimately associated with the cluster". ${ }^{1-3}$ Metal clusters are now very familiar not only to molecular chemists, i.e. coordination and organometallic chemists, but also to specialists of solid-state and physical chemistry since metal-metal bonding can occur in molecular compounds, inorganic solids (e.g. oxides, chalcogenides, halides) or in the gas phase (e.g. alkali metals). If one extends the original definition to include carbon and the remarkable fullerenes, even organic chemistry becomes concerned with clusters. This is not unreasonable when considering that boron has long been accepted "in the club", in the form of boranes and carboranes whose structures and bonding have helped considerably understand the structural chemistry of transition metal clusters. ${ }^{4-6}$ Thus, all branches of chemistry, including materials sciences, nanosciences and catalysis, have become concerned, to a variable extent of course and for fundamental or applied reasons, with the study of element-element bonding.

During the last 20 years, several books have illustrated the rapid developments of cluster chemistry, its relevance to the synthesis of new chemical bonds, to a deeper understanding of chemical bonding, to the multisite reactivity and activation of small molecules, to homogeneous, supported and heterogeneous catalysis, and have emphasized its central role in nanosciences and its fruitful interfaces with biology and physics. ${ }^{7-21}$ One of the many facets of cluster chemistry that attracted considerable attention from the synthetic chemists was the fascinating possibility to link chemically different metals through direct metal-metal bonding, thus opening a new field where 1540 chemical bonds can be envisaged, just to mention the possibilities offered by 56 transition elements. If many of these heterometallic bonds have now been formed, either in dinuclear complexes or in mixed-metal clusters, many combinations still remain unknown. Associating metals that do not form alloys in the bulk state turned out to be possible at the molecular level, and the relevance of such "molecular alloys" to e.g. bimetallic catalysis attracted considerable attention., 7,

The first examples of heterometallic complexes containing a metal-metal bond between a group 11 metal $(\mathrm{Cu}, \mathrm{Ag}, \mathrm{Au})$ and another transition metal, such as $\mathrm{W}, \mathrm{Mn}, \mathrm{Fe}, \mathrm{Co}$, were published by Coffey, Lewis and Nyholm in $1964 .^{23}$ Such complexes allowed the authors to investigate the conditions favouring the formation of covalent metal-metal bonds by taking into account the electronic configuration and the effective electronegativity of the metal atoms. With its $\mathrm{d}^{10}$ electronic configuration, the coinage metal ion was found to behave like a pseudohalogen (cf. the similarity between e.g. $\left[\mathrm{Mn}(\mathrm{CO})_{5} \mathrm{Cl}\right]$ and $\left[\mathrm{Mn}(\mathrm{CO})_{5}-\right.$ 
$\left.\left.\mathrm{Au}\left(\mathrm{PPh}_{3}\right)\right]\right)$. Later, the similarity between $\left[\mathrm{Au}\left(\mathrm{PPh}_{3}\right)\right]^{+}$and $\mathrm{H}^{+}$was emphasized ${ }^{24-26}$ and further analyzed in terms of the isolobal analogy, a remarkably fruitful concept. ${ }^{27-29}$ Attempts were made to prepare and isolate a $\mathrm{Au}-\mathrm{Au}$ complex of the type $\left[\left(\mathrm{R}_{3} \mathrm{P}\right) \mathrm{Au}-\mathrm{Au}\left(\mathrm{PR}_{3}\right)\right](\mathrm{L}=$ phosphine) that would be isolobal to dihydrogen, but although a structural report has appeared in the literature for a complex that has not been fully described, ${ }^{30}$ stabilisation and full characterization of such a digold unit was achieved when coordinated to a $\mathrm{Pt}(\mathrm{II})$ centre in $\left[\mathrm{PtCl}\left(\mathrm{AuPPh}_{3}\right)_{2}\left(\mathrm{PEt}_{3}\right)_{2}\right]^{+}{ }^{31}$ With a d ${ }^{8} \mathrm{Pt}(\mathrm{II})$ centre and a formally neutral digold unit isolobal to $\mathrm{H}_{2}$, the two-electron, three-centre bonding involving the metals in this triangular structure is analogous to that in the well-known $2 \mathrm{e}_{3}{ }^{+}$system. In this first platinum-gold cluster, the $\mathrm{Au}-\mathrm{Au}$ distance of 2.737(3) $\AA$ is significantly shorter than in gold metal $(2.884 \AA){ }^{31}$

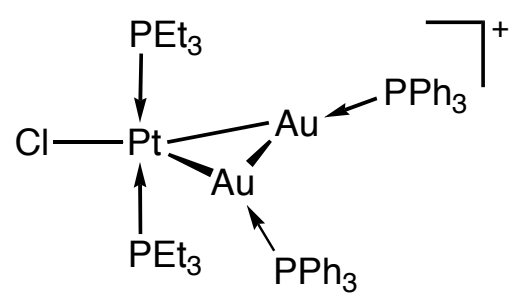

This complex was obtained by reaction of trans-[Pt(H)Cl( $\left.\left(\mathrm{PEt}_{3}\right)_{2}\right]$ with $\left[\mathrm{Au}\left(\mathrm{PPh}_{3}\right)\right]^{+}$with release of a proton. Similar approaches have led to e.g. $\mathrm{Mo}-\mathrm{Au}^{32}$ and $\mathrm{Fe}-\mathrm{Au}^{33}$ clusters in which the gold centres correspond to $\mathrm{Au}(\mathrm{I}) \mathrm{d}^{10}$ ions. The interest for generating and understanding interactions between metal centres with a $\mathrm{d}^{10}$ electronic configuration $\left(\mathrm{d}^{10}-\mathrm{d}^{10}\right.$ interactions) has been rapidly growing in chemistry because they had to involve concepts other than classical covalent or dative bonding. Best evidenced by X-ray diffraction studies, their attractive nature results in inter- or intramolecular distances which are shorter than the sum of van der Waals radii of the atoms concerned. Although van der Waals radii may not be ideal points of comparison when they do not derive from structures of existing systems, ${ }^{34}$ they are often used in the literature for benchmarking purpose and they will therefore also be used here in this context. They are more meaningful when they are obtained from intermolecular distances in molecular crystals. ${ }^{35,36}$ Being particularly significant in the case of gold, although closed-shell metal cations such as $\mathrm{Au}(\mathrm{I})\left([\mathrm{Xe}] 4 \mathrm{f}^{14} 5 \mathrm{~d}^{10}\right)$ could be expected to repel each other on the basis of electrostatics, the term of aurophilicity was introduced by Schmidbaur in 1988 to describe interactions between $\mathrm{Au}(\mathrm{I})$ centres which could not be explained by conventional concepts of chemical bonding. ${ }^{16,37-42}$ It should be recalled that attractive interactions between closed-shell $\mathrm{Cu}(\mathrm{I})-\mathrm{Cu}(\mathrm{I})$ and $\mathrm{Ag}(\mathrm{I})-\mathrm{Ag}(\mathrm{I})$ ions had already been recognised by Hoffmann in $1978^{43}$ and Jansen in 1980, respectively ${ }^{44,45}$ The aurophilicity concept suggests a new type of chemical bonding between gold atoms with the following characteristics: 
a) Steric effects permetting, the metal-metal distances are significantly shorter than the sum of the van der Waals radii $(3.7 \AA)$,

b) Several atoms can gather around a gold centre to form polynuclear species, such as triangles, squares, lozenges, etc... of gold atoms,

c) The bond energy associated with the interaction is generally small, in the order of magnitude of H-bonding, but larger than the energy of standard van der Waals contacts.

Early theoretical studies on the octahedral ions $\left[\left\{\mathrm{Au}\left(\mathrm{PH}_{3}\right)\right\}_{6} \mathrm{X}_{\mathrm{m}}\right]^{\mathrm{m}+}\left(\mathrm{X}_{1}=\mathrm{B}, \mathrm{X}_{2}=\mathrm{C}, \mathrm{X}_{3}=\mathrm{N}\right)$ used as models for a fascinating series of main-group-element-centred octahedral gold complexes, focused on the role of the gold $5 \mathrm{~d}$ atomic orbitals in Au-Au bonding. ${ }^{46}$ The participation of d-orbitals can be achieved only if the formal $\mathrm{d}^{10}$ configuration is broken, e.g. through $6 \mathrm{~s} / 5 \mathrm{~d}$ hybridisation. It was thus concluded that there is a prominent contribution of the gold $5 \mathrm{~d}$ atomic orbitals to the $\mathrm{Au}-\mathrm{Au}$ bonding within the cluster, via $6 \mathrm{~s} / 5 \mathrm{dz}^{2}$ hybridisation in the MOs of $\mathrm{a}_{1 \mathrm{~g}}$ symmetry. Furthermore, it was argued that the effect has its origin in the relativistic modification of the gold valence atomic orbitals energies, which brings the $5 \mathrm{~d}$ and $6 \mathrm{~s}$ orbitals into close energetic proximity. Investigating the origin of the aurophilic attraction, Pyykkö and Li concluded that the effect was primarily due to electron correlation rather than to $s-d$ hybridisation. ${ }^{47,48}$ The variation of the relativistic contraction of the $6 \mathrm{~s}$ shell for the elements ranging from $\mathrm{Cs}(Z=55)$ to $\mathrm{Fm}(Z=100)$ is represented in Figure 1 and a pronounced local minimum is observed for gold. Relativistic contributions to the bonding between gold ions, or between gold(I) and another $\mathrm{d}^{10}$ ion, will therefore be significant and relevant to the molecular and supramolecular chemistry of this element, including the use of structure-directing building blocks for the design of nanostructured functional materials. ${ }^{49}$

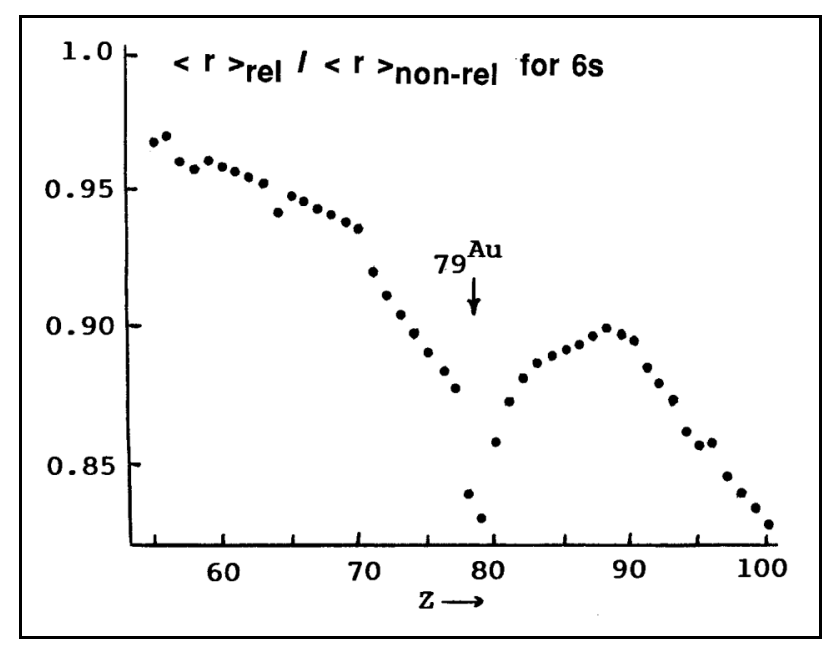

Figure 1. Variation of the ratio between relativistic and non-relativistic 6 s shell radii in the atomic ground states of the elements 55-100 as a function of $Z$ (Reprinted with permission from ref. 50 . 
Copyright American Chemical Society). A clear minimum is observed for Au, which corresponds to a maximum of the relativistic effects for this element.

"Metallophilic attraction" has been coined to broaden the concept of aurophilicity, ${ }^{48}$ and is best described as a correlation-dispersion phenomenon, enhanced by induction. This phenomenon continues to give rise to numerous theoretical investigations and developments. $^{36,41,51-63}$ Relativistic effects can result in an increase or a decrease of metallophilicity, depending on the system and the level of theory employed. An increase is found for aurophilicity at the MP2 level, but at the higher, coupled-cluster levels a weakening was recently reported. ${ }^{64}$

If aurophilicity manifests itself in a rapidly increasing number of molecules, in colloids and small particles, ${ }^{49,65}$ chemists rapidly became curious to see if a similar phenomenon could be observed for other closed shell or pseudo-closed shell elements. Thus for exemple, square-planar $\mathrm{d}^{8}$ complexes can be regarded as pseudo-closed shell systems owing to the strong ligand field splitting of the d orbitals. ${ }^{66,67}$

Remaining within the group 11 metals, it is particularly interesting to compare, experimentally and theoretically, $\mathrm{d}^{10}-\mathrm{d}^{10}$ interactions involving copper(I $)^{68-70}$ or silver(I) ${ }^{71-73}$ ions with those involving gold(I) ions in closely related complexes. Properties such as luminescence, catalysis, conductivity, magnetism and electrochemistry are strongly influenced by the occurrence of such $\mathrm{d}^{10}-\mathrm{d}^{10}$ interactions, either between molecules or within polynuclear and cluster compounds, and are thus relevant to potential applications in e.g. nanotechnologies and molecular-based electronics. Gold clusters are of course obvious candidates for the occurrence of such interactions but many of them contain formally both $\mathrm{Au}(0)$ and $\mathrm{Au}(\mathrm{I})$ centres. Intermolecular $\mathrm{d}^{10}-\mathrm{d}^{10}$ interactions are central to supramolecular gold chemistry, in much the same way as H-bonding in organic and coordination chemistry. Their strength is difficult to evaluate with precision since packing forces are also at work. The study of intramolecular $\mathrm{d}^{10}-\mathrm{d}^{10}$ interactions thus becomes particularly attractive. Whereas many reviews have appeared since 2000 which discuss various aspects of $\mathrm{d}^{10}-\mathrm{d}^{10}$ interactions, ${ }^{42,49,60,66,74-89}$ we will focus here on intramolecular $\mathrm{d}^{10}-\mathrm{d}^{10}$ interactions in heterometallic clusters of the transition metals, which are less represented in other reviews. Even in this case, it remains almost impossible to evaluate the energetic contribution of the attractive $\mathrm{d}^{10}-\mathrm{d}^{10}$ interactions to the global stabilization of the molecule considered since these will generally be supported by ancillary ligands or bridging metal atoms. As indicated above, interactions between metal ions with a closed-shell electronic configuration represent 
such a broad field that we will restricting ourselves to the relevant heterometallic clusters of the transition metals. We will therefore leave out complexes and clusters, even when heterometallic, involving elements from the groups 13 or 14, which in their low-valent state, may involved $\mathrm{d}^{10} \mathrm{~s}^{2}-\mathrm{d}^{10}$ rather than strictly $\mathrm{d}^{10}-\mathrm{d}^{10}$ interactions. We will not cover high nuclearity heterometallic clusters containing group 11 metals, which generally form the central core of their metal skeleton. The latter is often compared to the structures of the bulk metals and their complexity prevents a detailed discussion of $\mathrm{d}^{10}-\mathrm{d}^{10}$ interactions.

We will focus in particular on the nature of the metallic core and the resulting interactions between the $\mathrm{d}^{10}$ ions. First, we will consider intramolecular homometallic metallophilic interactions between $\mathrm{Cu}(\mathrm{I}), \mathrm{Ag}(\mathrm{I})$ or $\mathrm{Au}(\mathrm{I})$ ions in heterometallic complexes of the transition metals, then heterometallic $\mathrm{d}^{10}-\mathrm{d}^{10}$ interactions between these group 11 metals and finally some examples of intramolecular metallophilic interactions in heterometallic clusters involving at least one group 11 metal and, for comparison, in structurally related clusters with $\mathrm{d}^{10}$ metals from other groups. This review is not meant to be comprehensive but represents an attempt to categorize and relate to each other the situations encountered in this very rich and diversified field of chemistry.

To achieve a meaningful evaluation of the consequences of intramolecular $\mathrm{d}^{10}-\mathrm{d}^{10}$ interactions, in terms of structures and/or properties, requires to compare the synthesis, structure, and bonding of molecules as closely related as possible, in which only the nature of the $\mathrm{d}^{10}$ ion is varied, while keeping the other chemical parameters constant. The availability of sets of isoelectronic systems should provide unique opportunities for studying structure/bonding/reactivity relationships both experimentally and theoretically. In this review, we will not examine the theoretical aspects of the metallophilic interactions.

\section{Intramolecular homometallic $\mathbf{d}^{10}-\mathrm{d}^{10}$ interactions in heterometallic clusters.}

\section{1. $\mathrm{Cu}-\mathrm{Cu}$ interactions.}

Specific geometries of the metal core of heterometallic clusters appear to facilitate the development of $\mathrm{d}^{10}-\mathrm{d}^{10}$ interactions, such as the planar (rhomboidal) raft of six metals found in $\left[\mathrm{Cu}_{2} \mathrm{Re}_{4} \mathrm{H}_{16}\left(\mathrm{PMe}_{2} \mathrm{Ph}\right)_{8}\right]^{2+}$ (1) or the trigonal bipyramidal geometry in complex $\left[\mathrm{Ir}_{2} \mathrm{Cu}_{3} \mathrm{H}_{6}(\mathrm{MeCN})_{3}\left(\mathrm{PMe}_{2} \mathrm{Ph}\right)_{6}\right]^{3+}$ (2). ${ }^{90,91}$ Like planar clusters, 1 represents an attractive geometric model of a metal surface and the unique arrangement of the metals around the central $\mathrm{Cu}_{2}$ unit and the steric accessibility of copper suggest possible enhanced reactivity of this dication. In 2, the iridium atoms occupy the apical sites of the trigonal bipyramidal 
structure. Three phosphine ligands are facially coordinated to the pseudo-octahedral iridium centres and each copper is bonded to an acetonitrile ligand. The $\mathrm{Cu}-\mathrm{Cu}$ distances are $2.493 \AA$ in $\mathbf{1}$ and $2.57(2) \AA$ in 2.

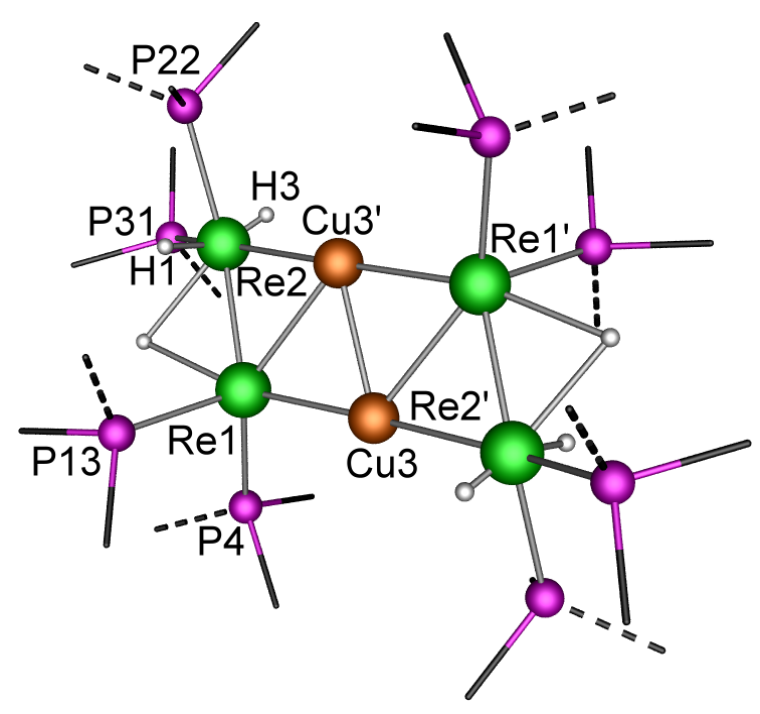

1

Only 6 of the 16 hydride ligands were located. The terminal phenyl groups have been omitted for clarity.

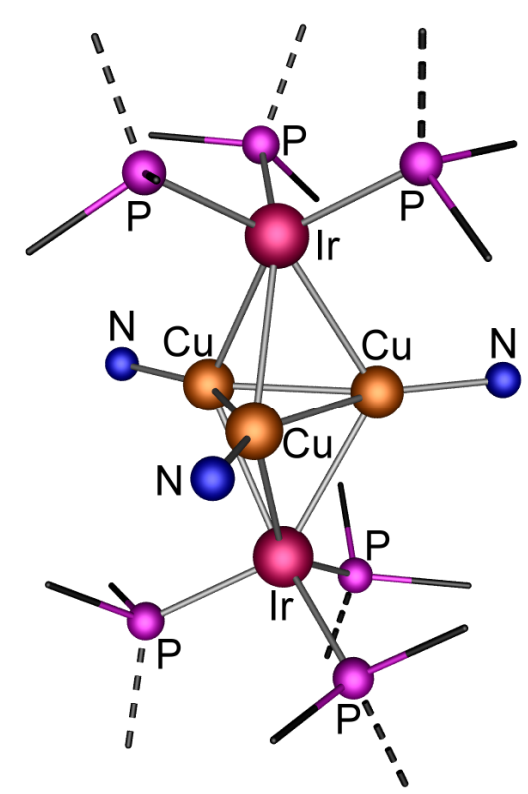

2

Only the metals and the inner coordination sphere donor atoms are shown. The 6 bridging hydride ligands between $\mathrm{Cu}$ and $\mathrm{Ir}$ are not represented.

The metal centres in the copper/iron mixed cluster $\left[\mathrm{Cu}_{3} \mathrm{Fe}_{3}(\mathrm{CO})_{12}\right]^{3-}(\mathbf{3})$ also form a planar skeleton which consists of a $v_{2}$-triangle (i.e., in a $v_{n}$-polyhedron, there are $n+1$ equally spaced atoms along each edge) in which the central $\mathrm{Cu}_{3}$ triangle is inscribed within the larger triangle formed by the three $\mathrm{Fe}(\mathrm{CO})_{4}$ groups. ${ }^{92,93}$ The distances between the copper atoms are found between 2.582(2) and 2.613(2) $\AA$. The $\mathrm{Cu}-\mathrm{Cu}-\mathrm{Cu}$ angles are in the range 59.25(4)$60.44(5)^{\circ}$ and the $\mathrm{Fe}-\mathrm{Cu}-\mathrm{Fe}$ angles in the range 174.26(7)-175.23(7) ${ }^{\circ}$. The $\mathrm{Cu}_{3} \mathrm{Os}_{3}$ core of $\left[\mathrm{Cu}_{3} \mathrm{Os}_{3} \mathrm{H}_{9}\left(\mathrm{PMe}_{2} \mathrm{Ph}\right)_{9}\right]$ (4) has also a $v_{2}$-triangular structure and the orientation of the three bridging $\mathrm{Os}\left(\mathrm{PMe}_{2} \mathrm{Ph}\right)_{3}$ groups is such that the molecule possesses a $C_{3}$ axis. ${ }^{94}$ The $\mathrm{Cu}-\mathrm{Cu}$ distances are equal to $2.626(3) \AA$ and all the Os-Cu-Os angles are within $3.6^{\circ}$ of $180^{\circ}$. 


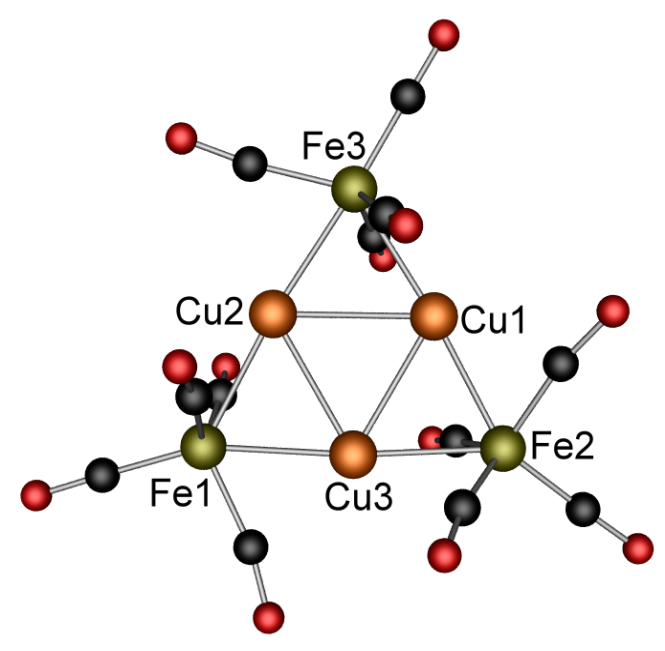

3

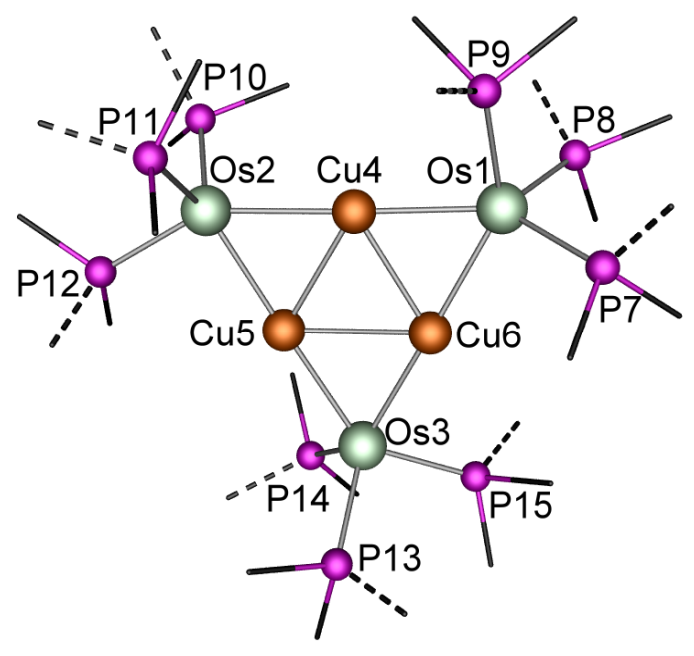

4

In the octanuclear copper-cobalt mixed cluster $\mathbf{5}$ described by Klüfers, the inner $\mathrm{Cu}_{4}$ square is inscribed within a $\mathrm{Co}_{4}$ square and each $\mathrm{Cu}-\mathrm{Cu}$ edge is bridged by a $\mathrm{Co}(\mathrm{CO})_{4}$ fragment, thus leading to a $v_{2}$-square structure. ${ }^{95}$ The values of the $\mathrm{Cu}-\mathrm{Cu}$ distances range from 2.703(4)2.731(4) $\AA$ and the $\mathrm{Co}-\mathrm{Cu}-\mathrm{Co}$ angles from $167.41(4)^{\circ}$ (at $\left.\mathrm{Cu}(1)\right)$ to $158.07(6)^{\circ}$ (at $\left.\mathrm{Cu}(2)\right)$, respectively.

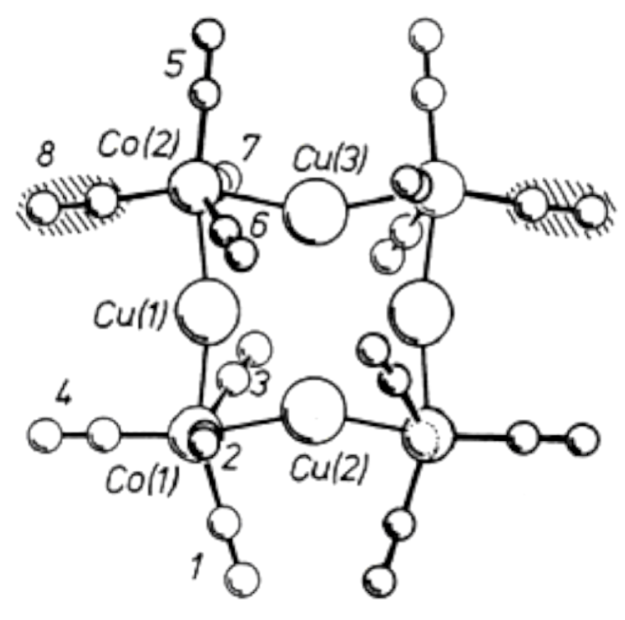

5

(Reproduced with permission from ref. 95. Copyright Wiley-VCH Verlag GmbH \& Co. KGaA)

The triangular and square geometries observed in these $\mathrm{Cu}(\mathrm{I})$ clusters thus appear to favour $\mathrm{d}^{10}-\mathrm{d}^{10}$ interactions. It is noteworthy that although the bridging metalloligands $\left[\mathrm{Fe}(\mathrm{CO})_{4}\right]^{2-}$ and $\left[\mathrm{Co}(\mathrm{CO})_{4}\right]^{-}$are isoelectronic and almost isosteric, they lead to a $v_{2}$-triangular and a $v_{2^{-}}$ square core structure in $\mathbf{3}$ and $\mathbf{5}$, respectively.

The reactions of $\left[\mathrm{Cu}(\mathrm{NCMe})_{4}\right] \mathrm{PF}_{6}$ with $\left[\mathrm{MoCp}(\mathrm{CO})_{3}\right]^{-}$or $\left[\mathrm{Mo}(\mathrm{CpNMe})_{2}(\mathrm{CO})_{3}\right]^{-}$ $\left(\mathrm{CpNMe}_{2}=\eta^{5}-\mathrm{C}_{5} \mathrm{H}_{4} \mathrm{NMe}_{2}\right)$ afforded the $v_{2}$-triangular clusters $\left[\mathrm{Cu}_{3}\left\{\mathrm{MoCp}(\mathrm{CO})_{3}\right\}_{3}\right](6)$ and $\left[\mathrm{Cu}_{3}\left\{\mathrm{Mo}\left(\mathrm{CpNMe}_{2}\right)(\mathrm{CO})_{3}\right\}_{3}\right](7)$, respectively, which like 3 and 4 , adopt a 2-D raft-type 
arrangement. ${ }^{62,96}$ The central $\mathrm{Cu}(\mathrm{I})$ core forms an almost equilateral metal triangle inscribed within a molybdenum triangle. The mean $\mathrm{Cu}-\mathrm{Cu}$ distances are similar in 6 and 7, 2.627(8) $\AA$ and 2.617(1) $\AA$, respectively, and much shorter than the sum of the van der Waals radii (2.80 $\AA$ ). These two clusters are very similar, except for the orientation of the metalloligands with respect to the $\mathrm{Cu}-\mathrm{Cu}$ edge they bridge. The $\mathrm{Mo}(1)-\mathrm{Cu}(1)-\mathrm{Mo}(2), \mathrm{Mo}(2)-\mathrm{Cu}(2)-\mathrm{Mo}(3)$ and $\mathrm{Mo}(3)-\mathrm{Cu}(3)-\mathrm{Mo}(1)$ angles are $175.92(5)^{\circ}, 177.87(5)^{\circ}, 171.25(5)^{\circ}$ for $\mathbf{6}$ and $175.50(2)^{\circ}$, $173.41(2)^{\circ}, 176.85(2)^{\circ}$ for 7 , respectively.

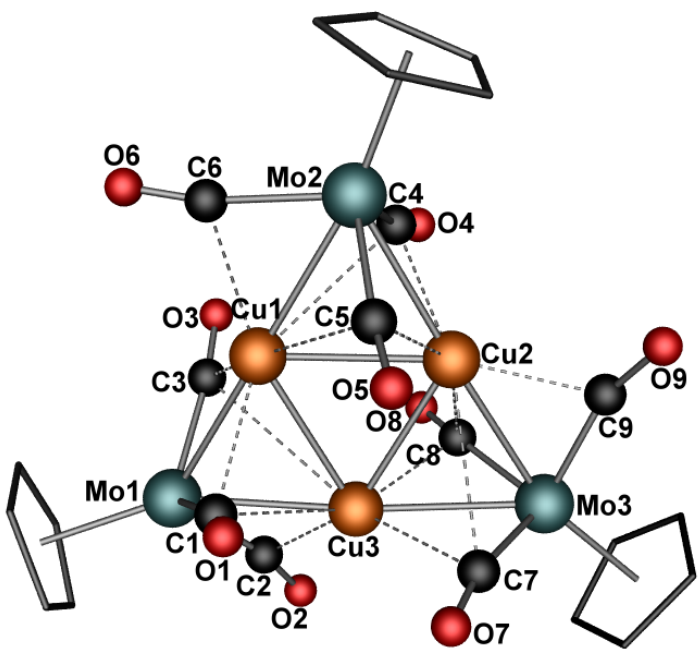

6

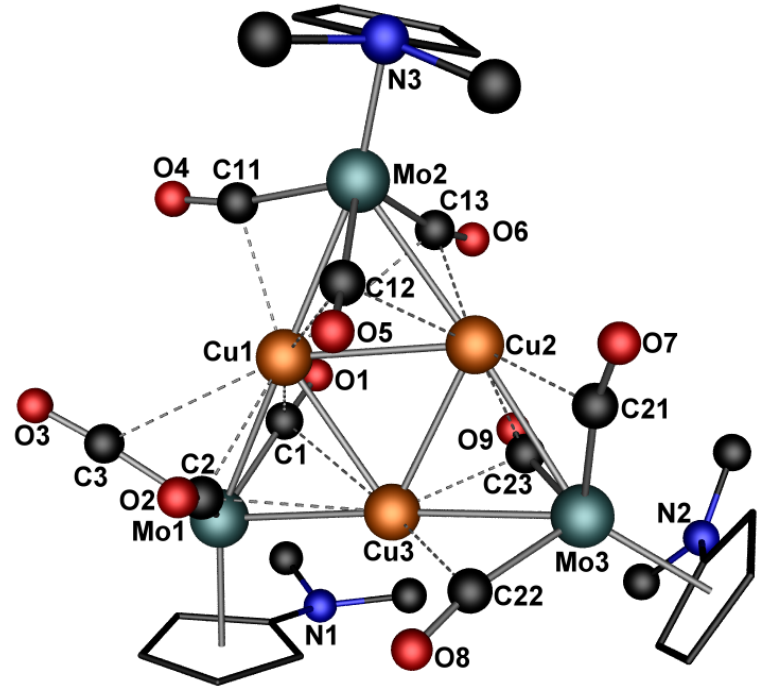

7

A similar reaction between $[\mathrm{CuCl}(\mathrm{tmed})]\left(\mathrm{tmed}=\mathrm{N}, \mathrm{N}, \mathrm{N}^{\prime}, \mathrm{N}^{\prime}\right.$-tetramethylethylendiamine) and $\mathrm{Na}\left[\mathrm{MCp}(\mathrm{CO})_{3}\right](\mathrm{M}=\mathrm{Cr}, \mathrm{Mo}, \mathrm{W})$ afforded the dinuclear complex [(tmed)Cu$\left.\left\{\mathrm{MCp}(\mathrm{CO})_{3}\right\}\right]$ (8) in which the tmed ligand remained chelated to copper, thus preventing cluster formation. $^{97}$

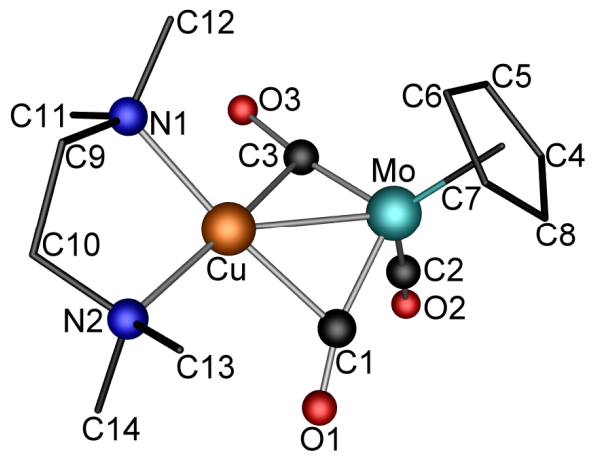

8

In clusters 1-7, the $\mathrm{Cu}-\mathrm{Cu}$ distances are close to the sum of the metal atom radii $(2.556 \AA)$ but shorter than the sum of the van der Waals radii $(2.80 \AA),{ }^{34,98}$ which suggests attractive metallophilic interactions between the $\mathrm{Cu}$ centres. These distances are even 
comparable to the sum of the covalent radii of $2.64 \AA$ proposed by Alvarez. ${ }^{99}$ Notably shorter $\mathrm{Cu}-\mathrm{Cu}$ distances are found in the $v_{2}$-triangular compared to the $v_{2}$-square structures.

Interestingly, heterobimetallic clusters of $\mathrm{Cu}(\mathrm{I})$ with core geometries related to the square arrangement found in $\mathbf{5}$ have been observed which do not display $\mathrm{d}^{10}-\mathrm{d}^{10}$ interactions, as in e.g. the octanuclear $\left[\mathrm{Et}_{4} \mathrm{~N}\right]_{4}\left[\mathrm{M}_{4} \mathrm{Cu}_{4} \mathrm{~S}_{12} \mathrm{O}_{4}\right](\mathrm{M}=\mathrm{Mo}, \mathrm{W})(9)$ and the dodecanuclear clusters $\left[\mathrm{M}_{4} \mathrm{Cu}_{4} \mathrm{~S}_{12} \mathrm{O}_{4}\{\mathrm{Cu}(\text { tmen })\}_{4}\right] \quad(\mathrm{M}=\mathrm{Mo}, \mathrm{W} ;$ tmen $=N, N, N, N$-tetramethyl ethylenediamine) (10). ${ }^{100}$ The eight metal atoms in the former cluster form a distorted $v_{2^{-}}$ square arrangement, with sulphur atoms doubly or triply bridging the metals. The derived dodecanuclear cluster $\mathbf{1 0}$ can be considered as formed of a $\left[\mathrm{M}_{4} \mathrm{Cu}_{4} \mathrm{~S}_{12} \mathrm{O}_{4}\right]^{4-}$ unit linked to four $\mathrm{Cu}$ (tmen) $)^{+}$groups at each $\mathrm{M}$ atom. These $\mathrm{Cu}(\text { tmen })^{+}$groups are positioned alternately on one and the other side of the $\mathrm{Cu}_{4} \mathrm{M}_{4}$ square. The $\mathrm{Cu}-\mathrm{Cu}$ separations, in the range 5.415(1)5.515(1) $\AA$ for 9 and 5.236(1)-5.354(1) $\AA$ for 10, are much too large to allow direct interactions between the copper centres. These two examples serve to illustrate that if some structural core arrangements appear favorable for the occurrence of metallophilic interactions, other parameters such as the nature and position of the ligands play an important role.

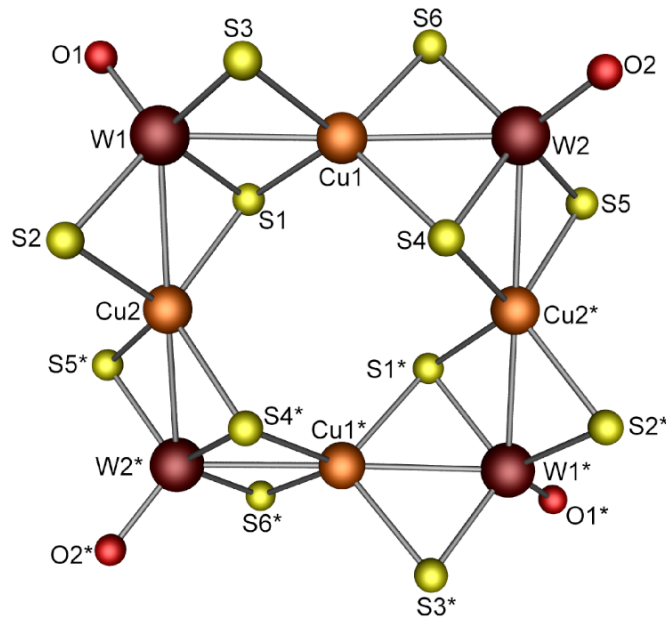

9

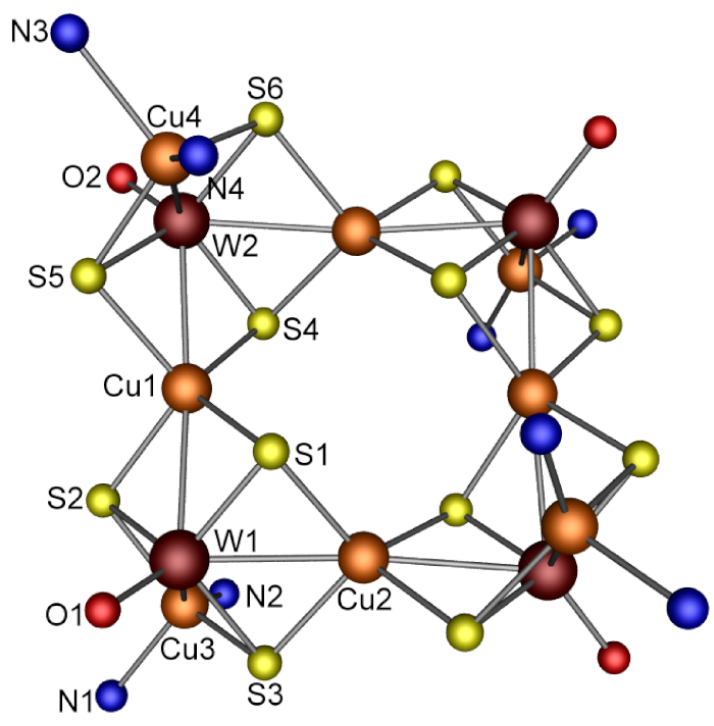

10

$\mathrm{C}$ atoms are omitted for clarity

It is interesting to compare the $\mathrm{Cu}-\mathrm{Cu}$ distances found in the heterometallic clusters of type $\{\mathrm{M}[\mathrm{m}]\}_{\mathrm{n}}(\mathrm{M}=\mathrm{Cu}, \mathrm{n}=3$ or 4$)$ mentioned above with those in e.g. the homometallic copper square $\left[\mathrm{Cu}_{4}\left(\mu-\mathrm{C}_{4} \mathrm{H}_{3} \mathrm{~S}\right)_{4}\right] \quad(\mathbf{1 1})^{101}$ or the copper-cobalt cluster $\left[\mathrm{Cu}_{3}\left\{\mu_{2}-\right.\right.$ $\left.\left.\left(\mathrm{CCHCo}_{2}(\mathrm{CO})_{6}\right)\right\}_{3}\right]$ (12). The latter contains a triangular $\mathrm{Cu}(\mathrm{I})$ core surrounded by $\mathrm{CCHCo}_{2}(\mathrm{CO})_{6}$ moieties, each copper being bonded to two cobalt atoms and one carbon, with 
an average value for the short $\mathrm{Cu} \cdots \mathrm{Co}$ non-bonding distance of $2.584 \AA .^{102}$ The $\mathrm{Cu}-\mathrm{Cu}$ distances in 11 and 12, in the range 2.453(3)-2.507(3) $\AA$ and 2.494(2)-2.508(2) $\AA$, respectively, are short enough to allow cuprophilic interactions.

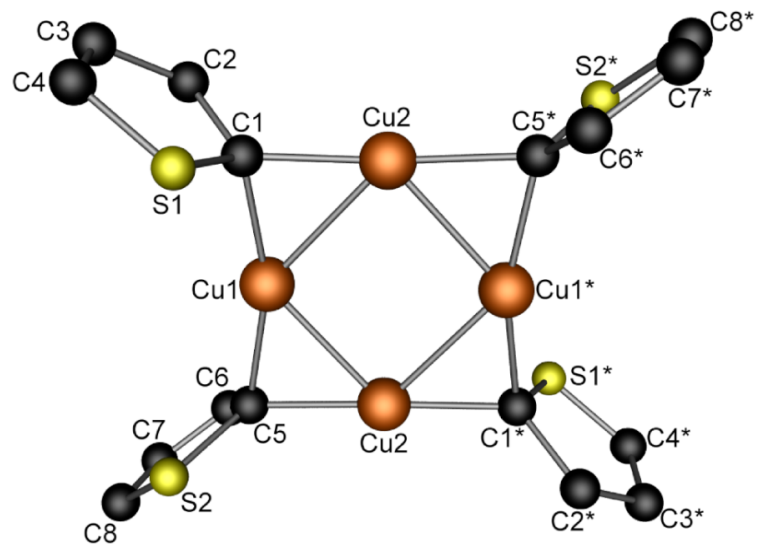

11

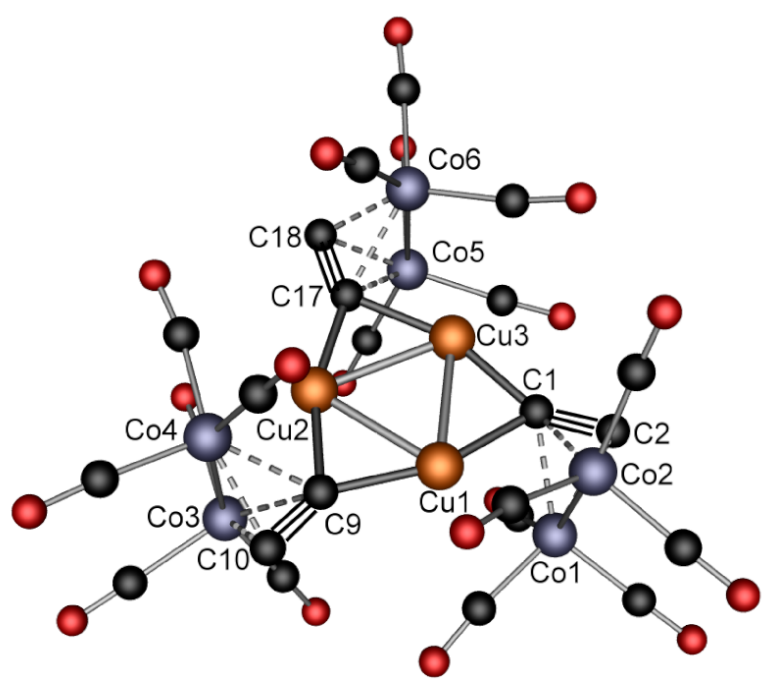

12

\subsection{Ag-Ag Interactions}

The metal core of the $\mathrm{Pt}(\mathrm{II})-\mathrm{Ag}(\mathrm{I})$ cluster $\left[\mathrm{Ag}_{2}\left\{\mathrm{PtMe}_{2}(\mathrm{~N}, \mathrm{~N})\right\}_{2}\right](\mathrm{OTf})_{2}(\mathrm{~N}, \mathrm{~N}$ is a diimine ligand) forms a $\mathrm{Ag}_{2} \mathrm{Pt}_{2}$ parallelogram whose $\mathrm{Ag}-\mathrm{Ag}$ diagonal has a length of 2.6972(2) $\AA .{ }^{103}$ When $\mathrm{Cu}(\mathrm{I})$ was used as a precursor in place of $\mathrm{Ag}(\mathrm{I})$, a dinuclear $\mathrm{Pt}-\mathrm{Cu}$ complex was obtained instead, consistent with argentophilic interactions being stronger than cuprophilic interactions. An unusual square pyramidal $\mathrm{Ag}_{4} \mathrm{Au}$ cluster has been characterized in which the distances between the four basal $\mathrm{Ag}(\mathrm{I})$ centres were in the range 2.8424(8)-2.9396(7) $\AA{ }^{104}$

In 1985, the cationic cluster $\left.\left[\mathrm{Ag}_{3} \mathrm{Rh}_{3} \mathrm{H}_{9} \text { (tripod) }\right)_{3}\right]^{3+}(\mathbf{1 3})$ was obtained by reaction of a methanolic solution of $\left[\mathrm{RhCl}_{3}\right.$ (tripod)] with 4 equiv. of $\mathrm{AgCF}_{3} \mathrm{SO}_{3}{ }^{105}$ Its almost planar metal core forms an equilateral $v_{2}$-triangle in which the $\mathrm{Ag}_{3}$ core is bridged on all three edges by rhodium atoms. All the Ag- $\mathrm{Rh}$ bonds are hydrogen-bridged and there is an alternation of single and double bridges around the Rh triangle. This structural assignment was supported by the alternation of the Ag-Rh distances, which show shorter contacts (2.795(4)-2.807(4) $\AA$ ) where a double hydrogen bridge has been postulated and longer contacts (2.884(4)-2.933(4) $\AA$ ) for the single bridges. The Ag-Ag distances are in the range 2.968(4)-2.998(4) $\AA$ and much shorter than the sum of the van der Waals radii for silver (3.44 $\AA$ ). 


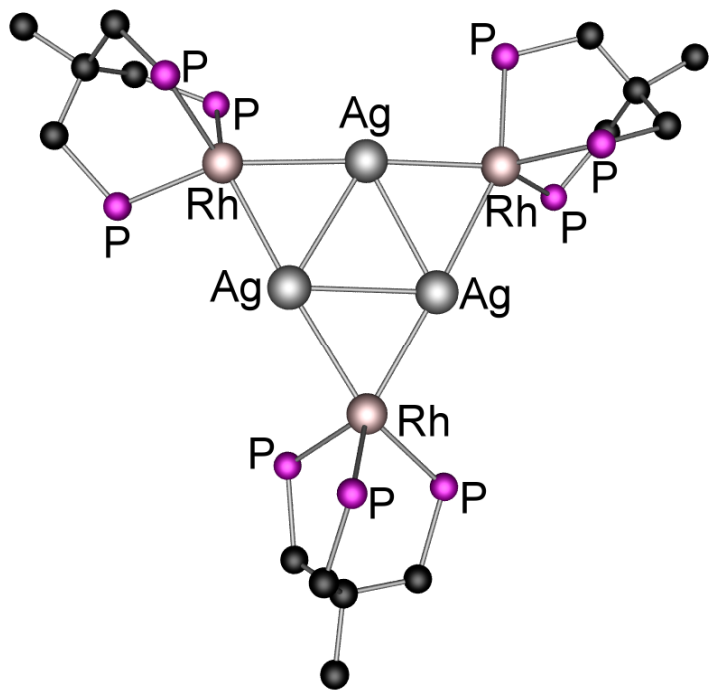

13

The terminal phenyl groups have been omitted for clarity.

The hydride positions are not indicated. ${ }^{105}$

The first structurally characterized carbonyl clusters of the type $\left[\operatorname{AgM}(\mathrm{CO})_{4}(\mathrm{dmpe})\right]_{3}$ $\left(\mathrm{M}=\mathrm{Nb}, \mathrm{Ta} ; \mathrm{dmpe}=1,2\right.$ bis(dimethylphosphino)ethane) (14) were reported in 1989. ${ }^{106}$ These clusters were isolated from the reaction of $\mathrm{NEt}_{4}\left[\mathrm{M}(\mathrm{CO})_{4}(\mathrm{dpme})\right]$ with $\mathrm{AgNO}_{2}$ or $\mathrm{AgBF}_{4}$ in THF at room temperature in a 1:1 molar ratio. The solid state structures of 14a (M $=\mathrm{Nb})$ and $\mathbf{1 4 b}(\mathrm{M}=\mathrm{Ta})$ are isotypic. In these $v_{2}$-triangular raft-clusters, the $\mathrm{Ag}_{3}$ core is bridged on all three edges by niobium or tantalum atoms. The almost identical Ag-Ag distances of 2.8424(5) $\AA$ are in the range of those found in the literature (median value from CCSD Nov. 2008: $3.016 \AA$, $\sigma=0.20 \AA$ for 3343 samples).

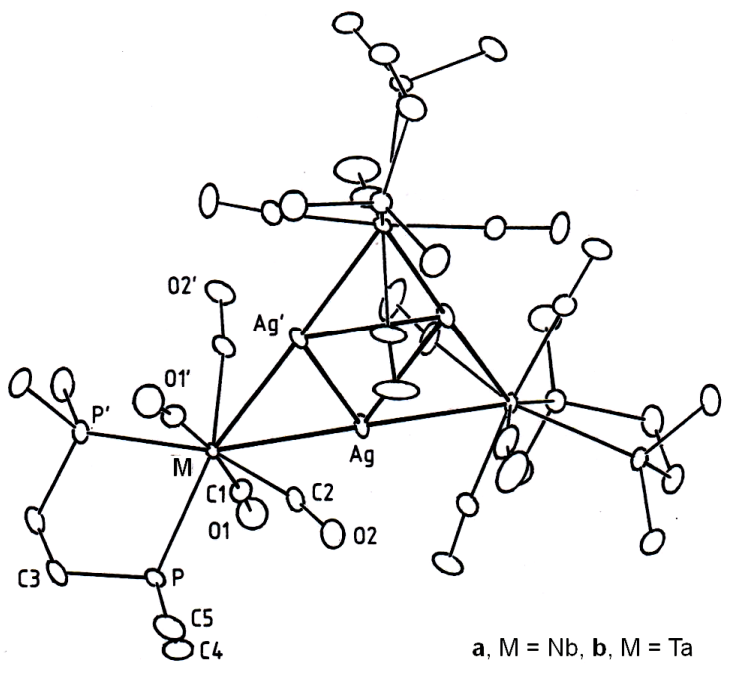

14

(Reproduced with permission from ref. 106.

Copyright Wiley-VCH Verlag GmbH \& Co. KGaA) 
The first octanuclear heterometallic cluster $\mathrm{Ag}_{4} \mathrm{M}_{4}^{\prime}$ analogous to the $\mathrm{Cu}_{4} \mathrm{M}_{4}^{\prime}$ cluster 5 was described by Klüfers. ${ }^{107}$ The centrosymmetric silver-cobalt cluster $\mathbf{1 5}$ contains a planar metal core and each $\mathrm{Ag}-\mathrm{Ag}$ edge of the central square is bridged by a $\mathrm{Co}(\mathrm{CO})_{4}$ fragment in such a way that this square is inscribed within a slightly distorted cobalt square ( $v_{2}$-square structure). The Ag-Ag distances are in the range 3.01(1)-3.03(2) $\AA$, and the inward bending of the $\mathrm{Co}(1)-\mathrm{Ag}-\mathrm{Co}(2)$ angle $\left(161.25(4)^{\circ}\right)$ is consistent with attractive argentophilic interactions.

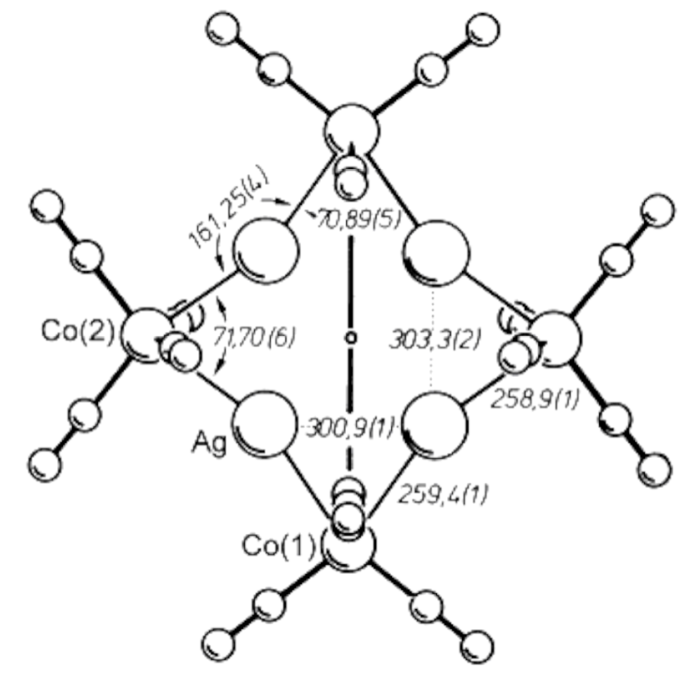

15

The related anionic cluster $\left[\mathrm{Ag}_{4}\left\{\mathrm{Fe}(\mathrm{CO})_{4}\right\}_{4}\right]^{4-}$ (16) was reported in 1994 by Longoni et al. who also provided a bonding analysis. ${ }^{108}$ It was selectively obtained by reaction of $\mathrm{AgBF}_{4}$ or $\mathrm{AgNO}_{3}$ with $\mathrm{Na}_{2}\left[\mathrm{Fe}(\mathrm{CO})_{4}\right] \cdot \mathrm{xTHF}$ in tetrahydrofuran and/or acetonitrile solution. Its structure contains an idealized $\mathrm{Ag}_{4}$ square (average Ag-Ag distance $3.149 \AA$ ) surrounded by four edgebridging $\mathrm{Fe}(\mathrm{CO})_{4}$ groups. These fragments adopt a $C_{2 \mathrm{v}}$ conformation and $\mathbf{1 6}$ has idealized $\mathrm{D}_{4 h}$ symmetry. The inward bending of the Fe-Ag-Fe linear sequences (average angle $165.4^{\circ}$ ) suggests, like in the case of $\mathbf{1 5}$, the occurrence of Ag-Ag attractive interactions. 


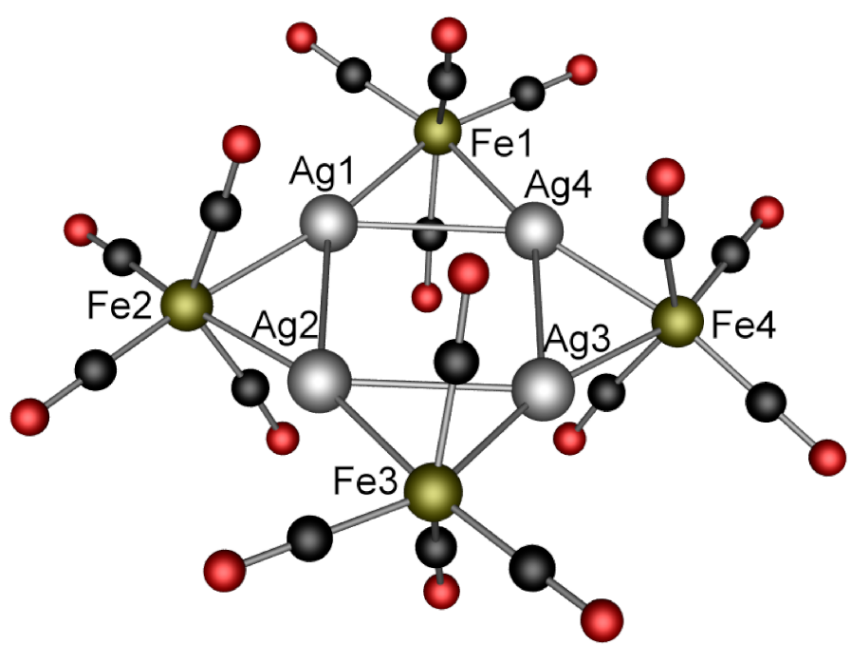

16

The $v_{2}$-square clusters $\left[\mathrm{Ag}_{4}\left\{\mathrm{MoCp}(\mathrm{CO})_{3}\right\}_{4}\right](\mathbf{1 7})^{62}$ and $\left[\mathrm{Ag}_{4}\left\{\mathrm{Mo}\left(\mathrm{CpNMe}_{2}\right)(\mathrm{CO})_{3}\right\}_{4}\right](\mathbf{1 8})^{96}$ were recently characterized and are interestingly related to $\mathbf{1 5}$ and $\mathbf{1 6}$. The mean $\mathrm{d}^{10}-\mathrm{d}^{10}$ distances within the silver square of 17 (2.8703(1) $\AA)$ and 18 (2.8687(1) $\AA$ ) are similar, they are much shorter than the sum of the van der Waals radii for silver (3.44 $\AA$ ) and even comparable to the sum of the covalent radii of $2.90 \AA .{ }^{99}$ The main difference between clusters $\mathbf{1 7}$ and $\mathbf{1 8}$ is to be found in the orientation of the metalloligands with respect to the Ag-Ag edge they bridge. The Mo-Ag-Mo angles are $147.80(3)^{\circ}$ for $\mathrm{Ag}(1)$ and $163.56(3)^{\circ}$ for $\operatorname{Ag}(2)$ in 17 and $149.81(4)^{\circ}$ for $\operatorname{Ag}(1)$ and 157.55(3) ${ }^{\circ}$ for $\operatorname{Ag}(2)$ in $\mathbf{1 8}$ and the inward bending of these bonds is again consistent with attractive argentophillic interactions.

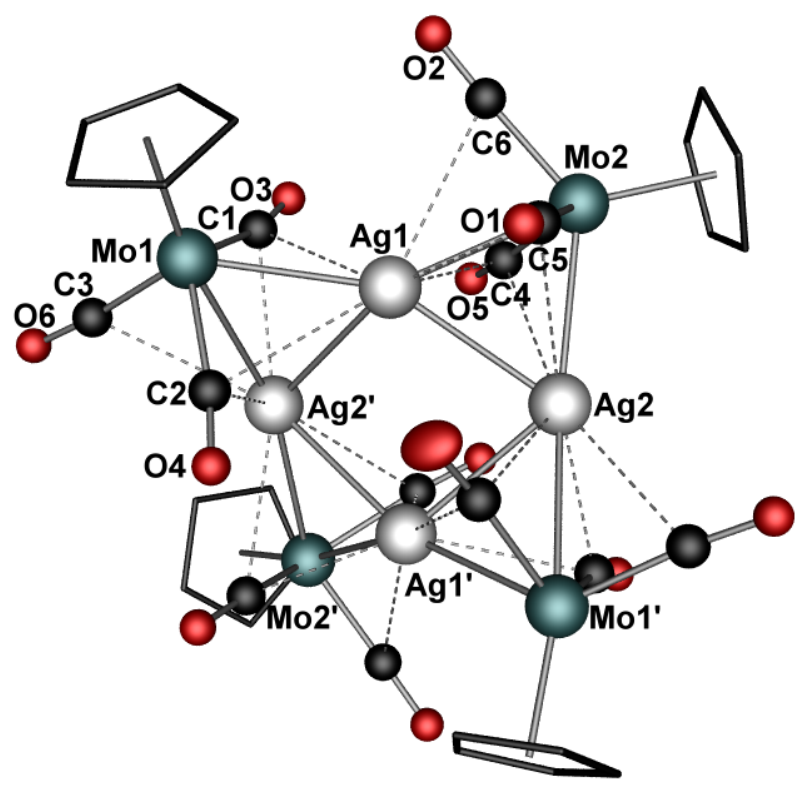

17

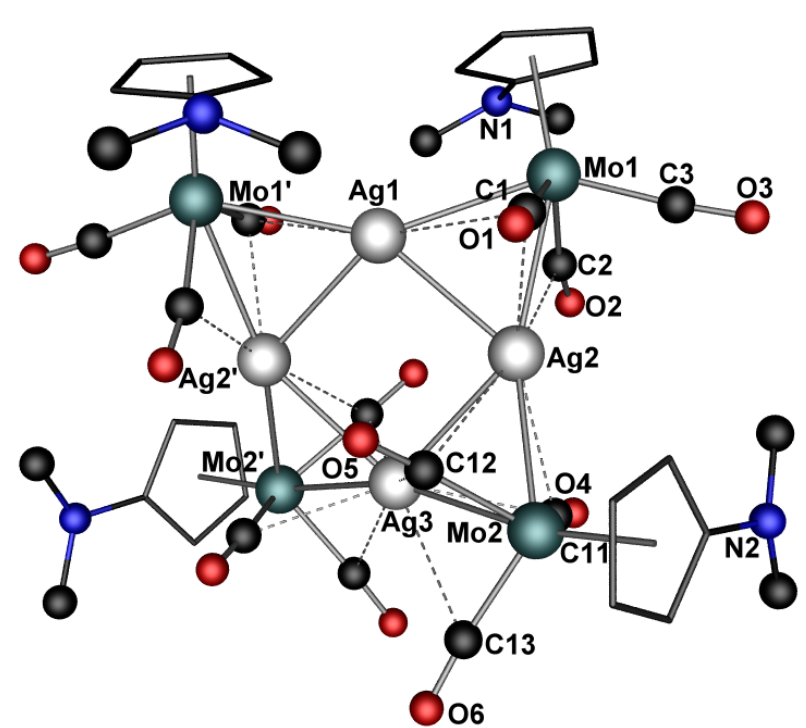

18

The structures of $\left[\mathrm{Ag}_{8} \mathrm{Fe}_{4}(\mathrm{CO})_{16}(\mathrm{dppm})_{2}\right](\mathbf{1 9})$ and $\left[\mathrm{Ag}_{4} \mathrm{Au}_{4} \mathrm{Fe}_{4}(\mathrm{CO})_{16}(\mathrm{dppe})_{2}\right](\mathbf{2 0})^{109}$ $(\mathrm{dppm}=$ bis(diphenylphosphine)methane, $\mathrm{dppe}=$ bis(diphenylphosphine)ethane) are 
organized around a central silver square whose edges are spanned by $\mathrm{Fe}(\mathrm{CO})_{4}$ groups which are placed alternately above and below the $\mathrm{Ag}_{4}$ plane. This arrangement is similar to that found in 16. The opposite vertices defining the long diagonal of the central square of $\mathbf{1 9}$ and 20 are bonded to $\mathrm{Ag}_{2}(\mathrm{dppm})$ and $\mathrm{Au}_{2}$ (dppe) fragments, respectively. The $\mathrm{d}^{10}-\mathrm{d}^{10}$ distances in the central silver square are short, with an average of $2.799 \AA$ for $\mathbf{1 9}$ and $2.755 \AA$ for $\mathbf{2 0}$. Cluster 19 represents a rare example of a neutral Ag-Fe cluster containing phosphines as ancillary ligands for silver.

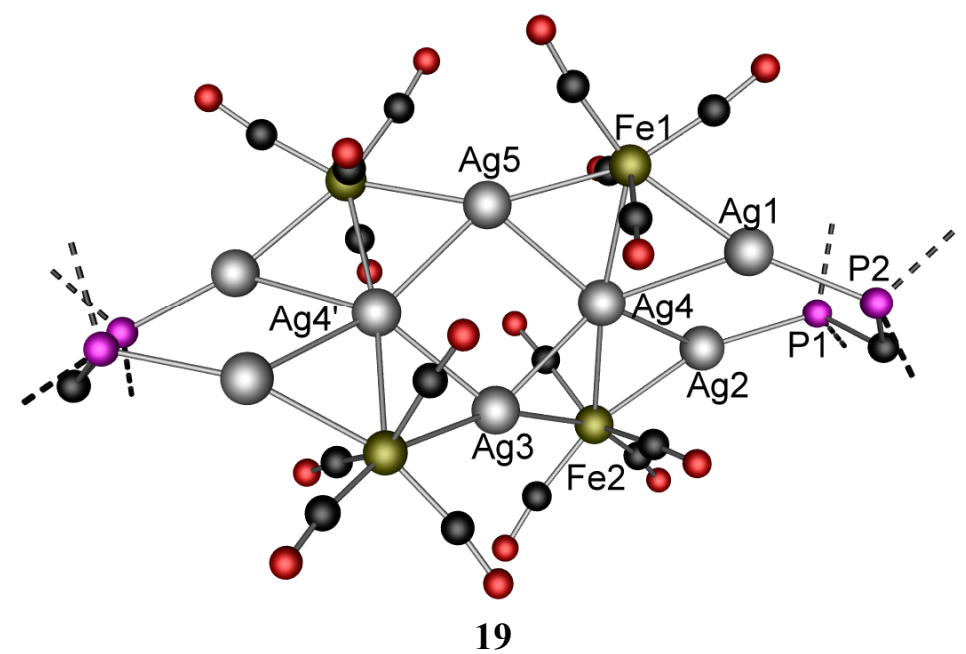

The terminal phenyl groups have been omitted for clarity.

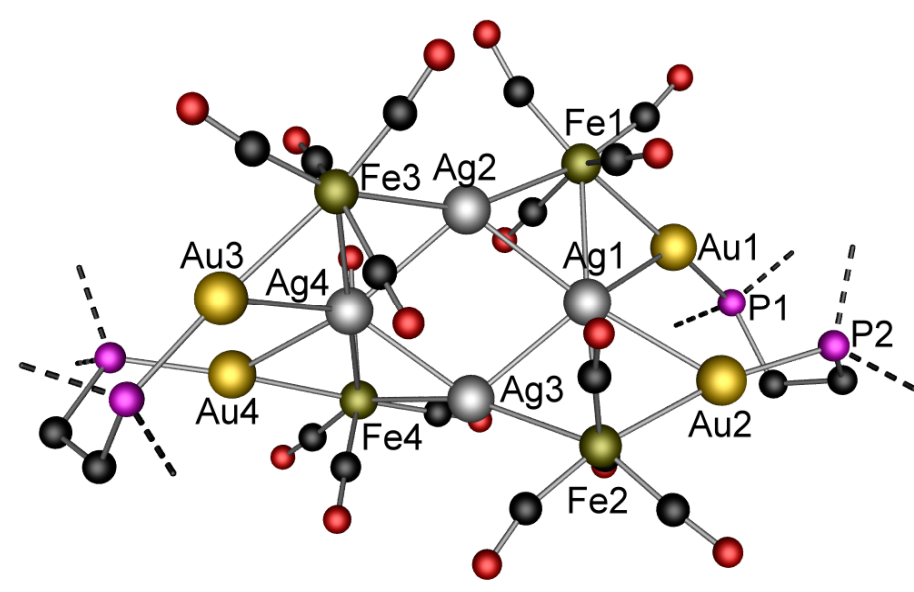

20

The terminal phenyl groups have been omitted for clarity.

An octanuclear cluster $\left[\left(\eta^{5}-\mathrm{C}_{5} \mathrm{Me}_{5}\right) \mathrm{WS}_{3} \mathrm{Ag}\right]_{4}(\mathbf{2 1})$ and an unusual helical polymer $\left\{\left[\left(\eta^{5}-\mathrm{C}_{5} \mathrm{Me}_{5}\right) \mathrm{WS}_{3}\right]_{2} \mathrm{Ag}_{3}(\mathrm{CN})\right\}_{\infty}(\mathbf{2 2})$ have been synthesised and structurally characterized. ${ }^{110}$ The authors reacted $\left(\mathrm{PPh}_{4}\right)\left[\left(\eta^{5}-\mathrm{C}_{5} \mathrm{Me}_{5}\right) \mathrm{WS}_{3}\right]$ with $\mathrm{AgCN}$ with the objective to introduce 
metal cyanide moieties into a cluster in view of the ability of the cyanide ligand to bridge between metal atoms, and obtained 21 and $\mathbf{2 2}$. However, the minor octanuclear cluster $\mathbf{2 1}$ did not contain cyanide ligand and was better synthesized by reaction of $\left(\mathrm{PPh}_{4}\right)\left[\left(\eta^{5}-\mathrm{C}_{5} \mathrm{Me}_{5}\right) \mathrm{WS}_{3}\right]$ with 1 equiv. of $\left[\mathrm{Ag}(\mathrm{NCMe})_{4}\right] \mathrm{PF}_{6}$ in $\mathrm{MeCN}$ (85\% yield). The $\mathrm{Ag}-\mathrm{Ag}$ separations in this cluster were too long to correspond to significant bonding between the $\mathrm{d}^{10}$ ions.

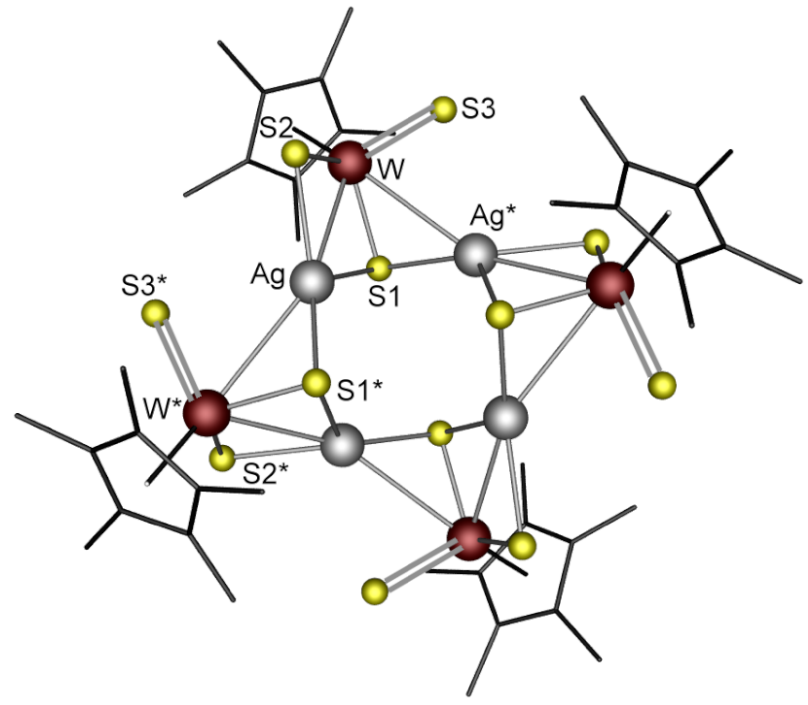

21

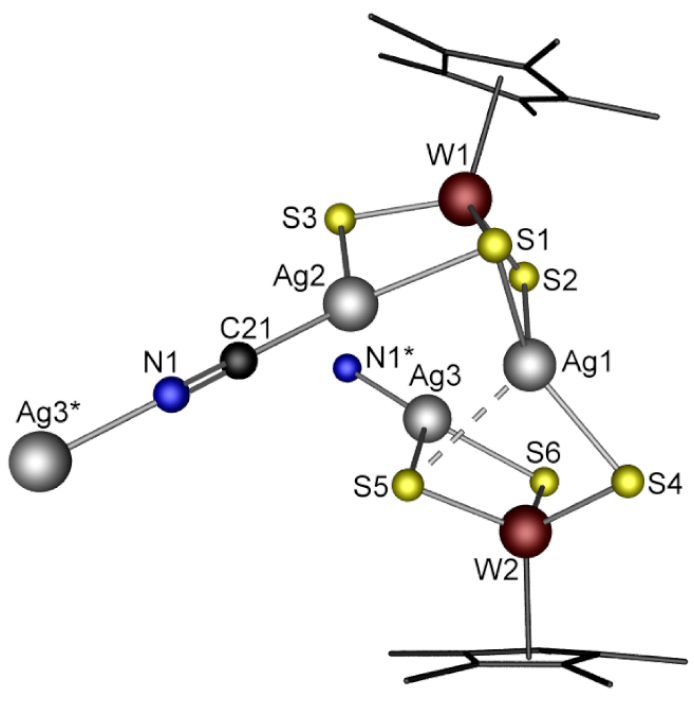

Structure of the repeat unit of $\mathbf{2 2}$

In contrast, the $\mathrm{Ag}-\mathrm{Ag}$ distances in the nearly symmetrical $\mathrm{Ag}_{3}$ cluster $\left[\mathrm{Ag}_{3}\left(\mathrm{CH}_{3} \mathrm{im}\left(\mathrm{CH}_{2} \text { py }\right)\right)_{2}(\mathrm{NCMe})_{2}\right]\left(\mathrm{BF}_{4}\right)_{3}(\mathbf{2 3})$, which was obtained from the N-heterocyclic carbene precursor 1-methyl-3-(2-pyridinylmethyl)-1H-imidazolium tetrafluoroborate, ${ }^{111}$ and in the square cluster $\left[\mathrm{Ag}_{4}(\mathrm{~L})_{2}\right]\left(\mathrm{PF}_{6}\right)_{4} \cdot \mathrm{Et}_{2} \mathrm{O} \cdot \mathrm{MeCN}(\mathbf{2 4})\left(\mathrm{H}_{2} \mathrm{~L}=2,6\right.$-bis(N-(pyridylmethyl) imidazoliumyl)pyridine $)^{73}$ are much shorter and similar to those in the heterometallic complexes of the type $\{\mathrm{Ag}[\mathrm{m}]\}_{\mathrm{n}}\left[\mathrm{m}=\mathrm{Nb}(\mathrm{CO})_{4}, \mathrm{Ta}(\mathrm{CO})_{4}, \mathrm{n}=3(\mathbf{1 4}) ; \mathrm{m}=\mathrm{Co}(\mathrm{CO})_{4}, \mathrm{Fe}(\mathrm{CO})_{4}\right.$, $\left.\mathrm{MoCp}(\mathrm{CO})_{3}, \mathrm{n}=4(\mathbf{1 5 - 1 8})\right]$ seen above. They are in the range 2.7598(8)-2.7832(8) $\AA$ for $\mathbf{2 3}$ and 2.784(1)-2.820(1) A for 24. 


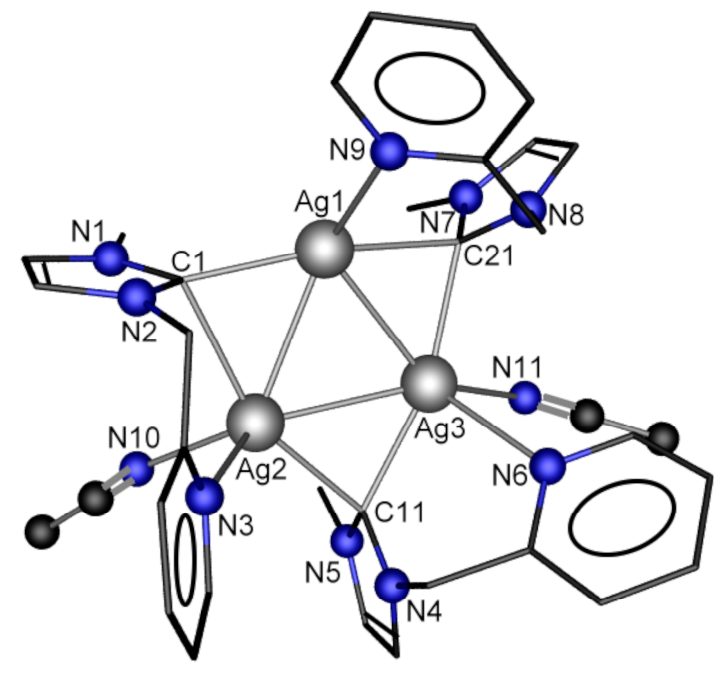

23

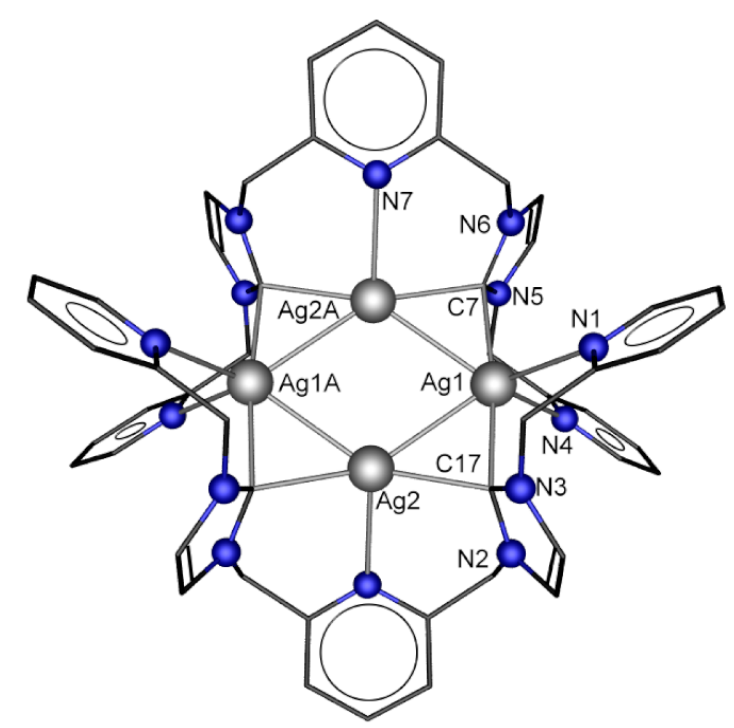

24

\subsection{Au-Au Interactions}

In 1981, the unusual mixed-metal cluster $\left[\left(\mathrm{Ph}_{3} \mathrm{PAu}\right)_{3} \mathrm{~V}(\mathrm{CO})_{5}\right]$ (25) was synthesized by treatment of the sodium or cesium salt of the pentacarbonylvanadate(3-) ion, $\left[\mathrm{V}(\mathrm{CO})_{5}\right]^{3-}$, with $\left[\mathrm{AuCl}\left(\mathrm{PPh}_{3}\right)\right]$ in THF. ${ }^{112}$ Its tetrahedral metal core contains three gold atoms and a eightcoordinated vanadium centre. The Au-Au distances are in the range 2.768(1)-2.855(1) $\AA$.

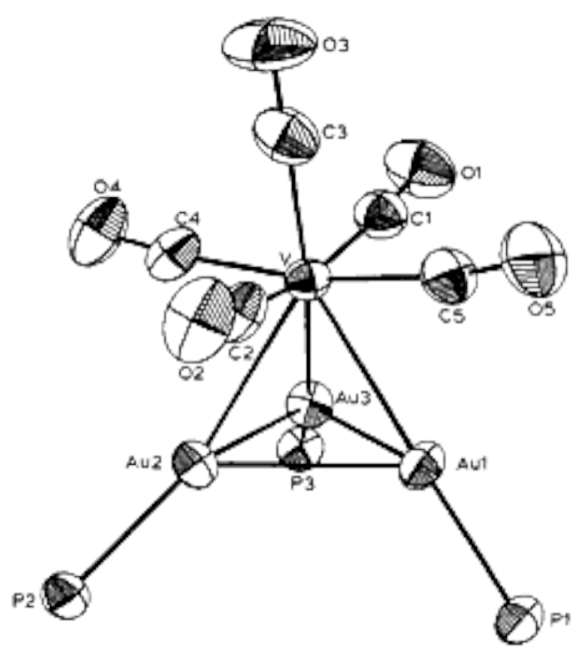

25

ORTEP of 25. The phenyl groups have been omitted for clarity.

(Reprinted with permission from ref. 112.

Copyright American Chemical Society)

$\mathrm{An} \mathrm{Au}_{2} \mathrm{Mo}_{4}$ phosphinidene complex with an unusual $\mathrm{H}$-shaped planar metal core has been characterized which exhibits an $\mathrm{Au}-\mathrm{Au}$ separation of $3.022(1) \AA^{113}$ The first heterometallic borole complexes of $\mathrm{Fe}$ and $\mathrm{Au}$ were reported in 1998 and include the $\mathrm{Au}_{2} \mathrm{Fe}$ cluster $\left[(\mathrm{OC})_{2}\left\{\eta^{5}-(1\right.\right.$-phenylborole $\left.\left.)\right\} \mathrm{Fe}\left\{\mathrm{Au}\left(\mathrm{PPh}_{3}\right)\right\}_{2}\right]$ (26) which was obtained by reaction of 
the metalate $\left[\mathrm{HFe}\left\{\eta^{5}-(1-\text { phenylborole })\right\}(\mathrm{CO})_{2}\right]^{-}$with $\left[\mathrm{AuCl}\left(\mathrm{PPh}_{3}\right)\right]$ in $\mathrm{CH}_{2} \mathrm{Cl}_{2} \cdot{ }^{33}$ The distance of 2.737(1) $\AA$ between the two $\mathrm{Au}(\mathrm{I})$ centres is significantly shorter than in gold metal $(2.884$ $\AA)$. This complex further reacts with $\left[\mathrm{AuCl}\left(\mathrm{PPh}_{3}\right)\right]$ to form a cationic $\mathrm{FeAu}_{3}$ cluster as the only product (eq. 1) in which the arrangement of the metals was established to be tetrahedral by a Wide Angle X-ray Scattering study. ${ }^{33}$

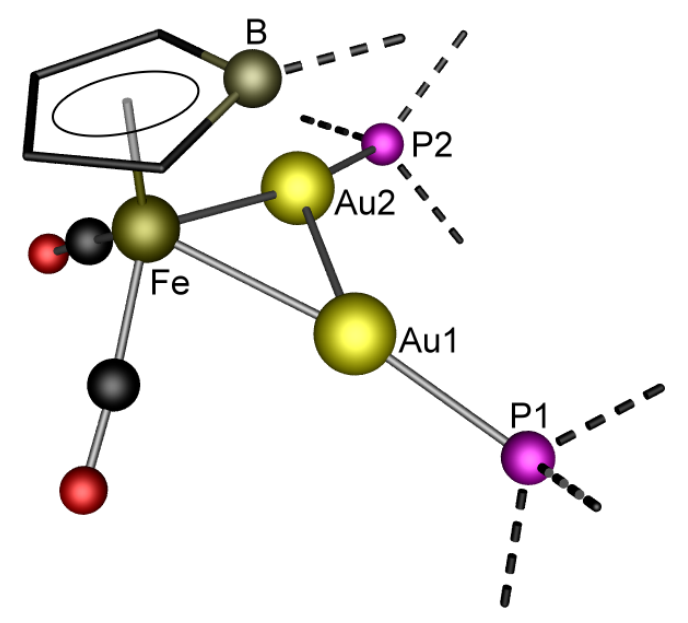

Perspective view of $\mathbf{2 6}$.

Phenyl groups have been omitted for clarity.

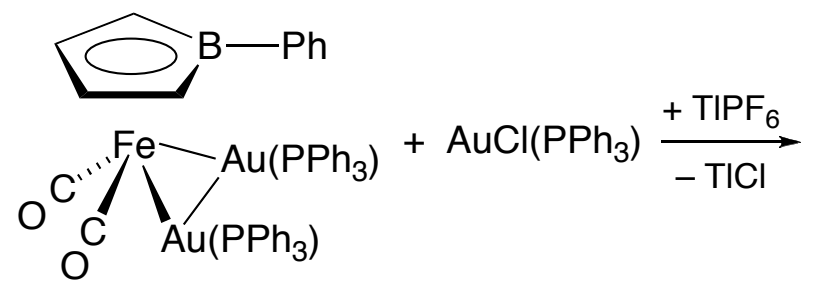

26

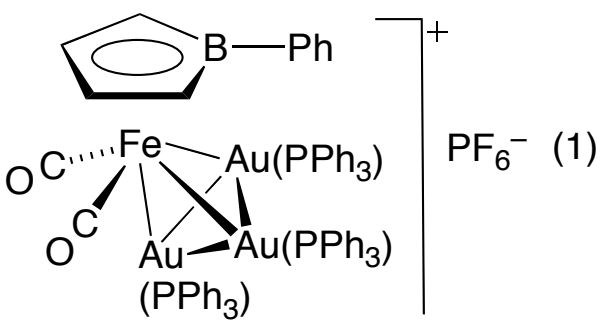

$\left(\mathrm{PPh}_{3}\right)$

A gold(I) triangle is also present in the cations $\left[\mathrm{Au}_{3}\left(\mu_{3}-\mathrm{O}\right) \mathrm{M}\left(\mu-\mathrm{PPh}_{2} \mathrm{py}\right)_{3}\right]^{2+}(\mathrm{M}=$ $\mathrm{Cu}(\mathrm{I}), \mathrm{Ag}(\mathrm{I}), \mathrm{PPh}_{2}$ py = diphenylphosphine-2-pyridine), which exhibits extremely bright luminescence in the solid-state at room-temperature. ${ }^{114,115}$ The $\mathrm{Au}-\mathrm{Au}$ contacts within the tetrahedral metal core were found in the range from 2.9801(6) to 3.0000(6) $\AA$ for $\mathrm{M}=\mathrm{Cu}$ and from 3.0661(3) to 3.2096(3) $\AA$ for $\mathrm{M}=\mathrm{Ag}$.

The reaction of $\left[\left(\mathrm{C}_{5} \mathrm{H}_{4} \mathrm{SiMe}_{3}\right)_{2} \mathrm{NbH}_{3}\right]$ with $\left[\mathrm{Au}\left\{\mathrm{N}\left(\mathrm{SiMe}_{3}\right)_{2}\right\}\left(\mathrm{PPh}_{3}\right)\right]$ produced the raft cluster $\left[\mathrm{NbAuH}_{2}\left(\mathrm{C}_{5} \mathrm{H}_{4} \mathrm{SiMe}_{3}\right)_{2}\right]_{3}$ (27) in high yield. ${ }^{116}$ Its structure consists of a gold triangle surrounded by three $\mathrm{Cp}_{2}{ }_{2} \mathrm{Nb}$ groups $\left(\mathrm{Cp}^{\prime}=\mathrm{C}_{5} \mathrm{H}_{4} \mathrm{SiMe}_{3}\right)$ and six bridging hydrides [Au-Au 
2.764(2), 2.757(2) and 2.780(3) §]. Molecular orbital calculations indicated a striking electronic stabilization of this geometry, which may be of importance in other gold hydrides.

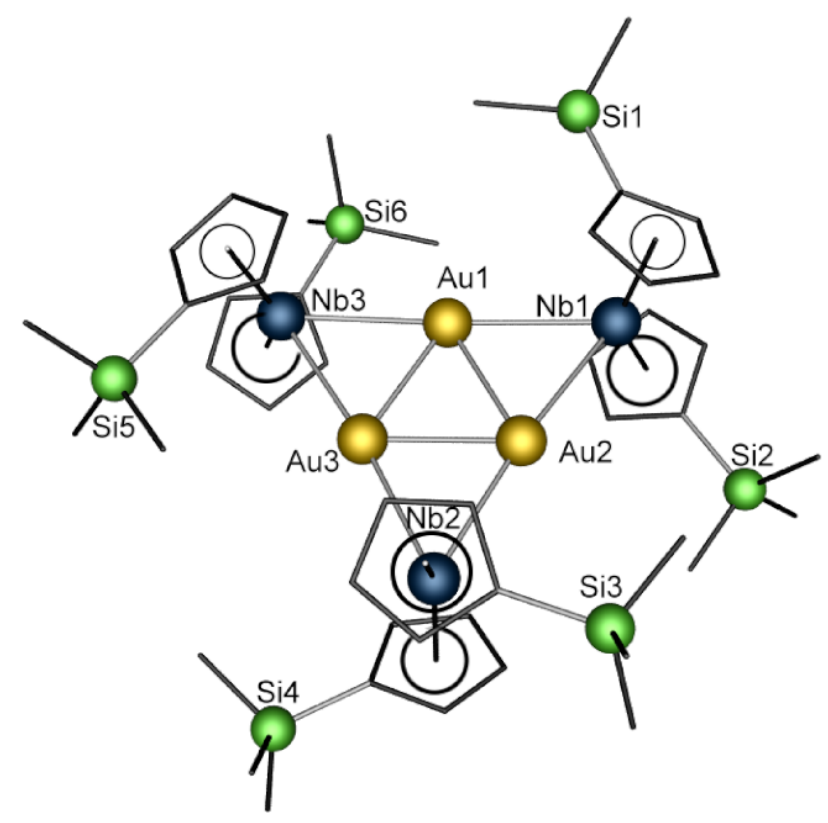

27

The 6 bridging hydride ligands between $\mathrm{Au}$ and $\mathrm{Nb}$ are not represented.

The dinuclear complex $\left[\mathrm{CpMo}(\mathrm{CO})_{3}\left(\mathrm{AuPPh}_{3}\right)\right]$, obtained by reaction of $\mathrm{Li}\left[\mathrm{MoCp}(\mathrm{CO})_{3}\right]$ with $\left[\mathrm{AuCl}\left(\mathrm{PPh}_{3}\right)\right]$ at $-95{ }^{\circ} \mathrm{C}$ in dichloromethane, reacted under $\mathrm{UV}$ irradiation with excess $\left[\mathrm{AuN}_{3}\left(\mathrm{PPh}_{3}\right)\right]$ to afford the cationic cluster $\left[\mathrm{CpMo}(\mathrm{CO})_{2}\left(\mathrm{AuPPh}_{3}\right)_{4}\right]^{+}$ (28). ${ }^{117}$ The five metal atoms form a trigonal bipyramid with the Mo atom occupying an equatorial position. The Au-Au distances in this cluster are in the range 2.812(1)-2.856(2) $\AA$.

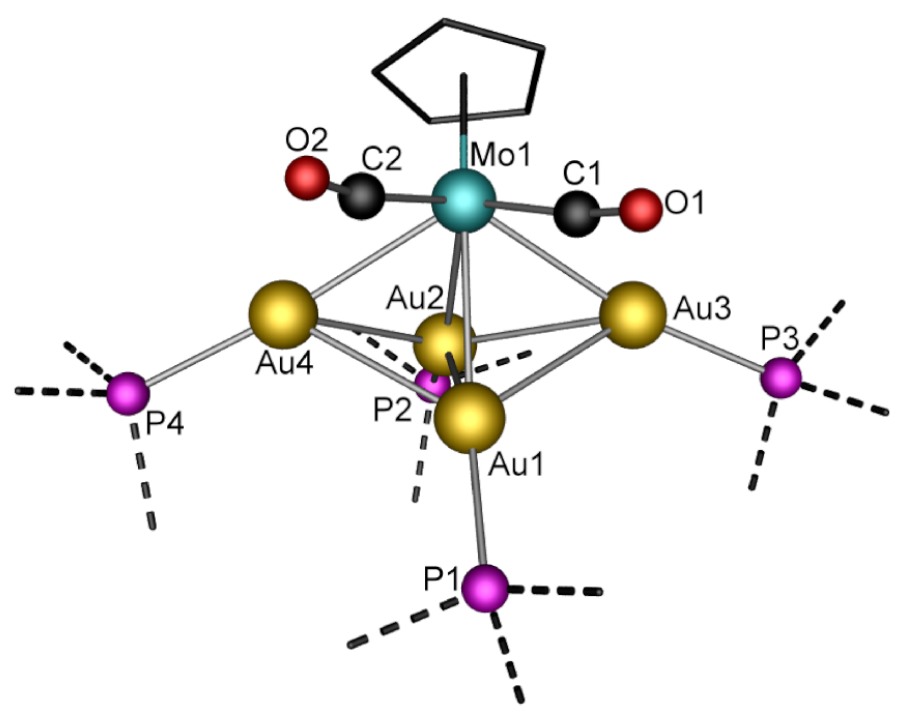

28

Phenyl groups have been omitted for clarity. 
The neutral, "square-in-a-square" or $v_{2}$-square clusters $\left[\mathrm{Au}_{4}\left\{\mathrm{MoCp}(\mathrm{CO})_{3}\right\}_{4}\right](\mathbf{2 9})$ and $\left[\mathrm{Au}_{4}\left\{\mathrm{Mo}(\mathrm{CpNMe} 2)(\mathrm{CO})_{3}\right\}_{4}\right](\mathbf{3 0})$ display $\mathrm{Au}-\mathrm{Au}$ distances in the range 2.7417(8)-2.8030(9) $\AA$ and 2.7598(5)-2.8248(5) $\AA$, respectively. These are shorter than the sum of the van der Waals radii for silver $(3.34 \AA)^{34}$ and even comparable to the sum of the covalent radii of 2.72 $\AA$ proposed by Alvarez. ${ }^{99}$ The four Au atoms are not exactly coplanar, the $\mathrm{Au}-\mathrm{Au}-\mathrm{Au}$ angles are around $90^{\circ}$ and the Mo-Au-Mo angles between $150.99(3)^{\circ}$ and $154.29(3)^{\circ}$ for 29 and between $149.88(3)^{\circ}$ and $162.07(3)^{\circ}$ for 30. The inward bending of the Mo-Au-Mo units is consistent with attractive aurophilic interactions.

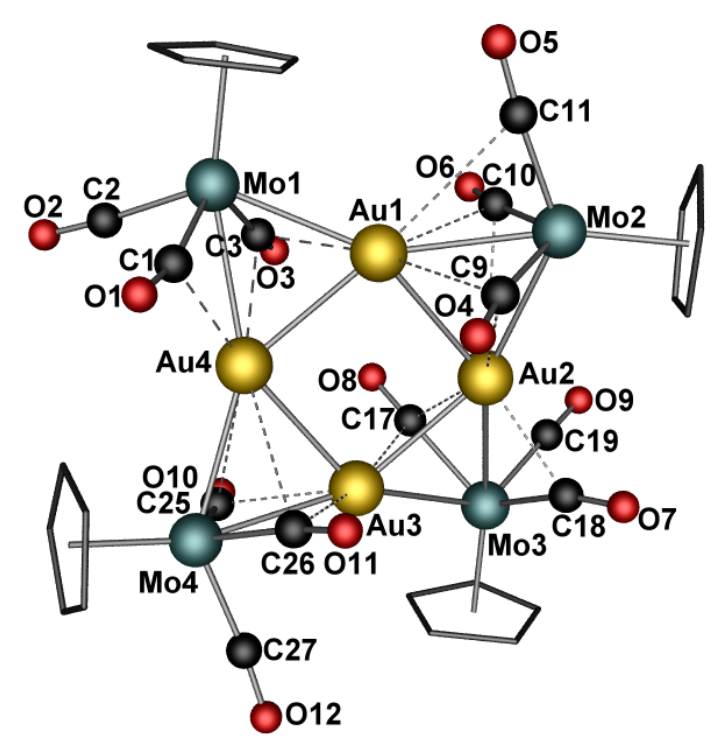

29

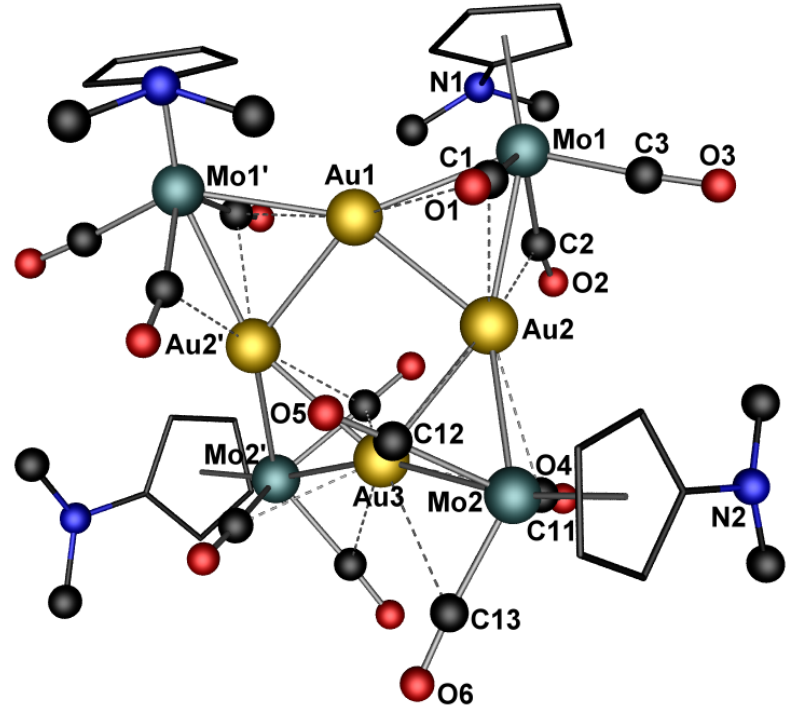

30

Cluster 29 could be synthesized directly by a 1:1 reaction between $\left[\mathrm{AuBr}_{2}\right]^{-118}$ and $\mathrm{Na}\left[\mathrm{MoCp}(\mathrm{CO})_{3}\right]^{62}$ or by reaction of $\left[\mathrm{AuBr}_{2}\right]^{-}$with the linear heterotrinuclear complex $[n-$ $\left.\mathrm{Bu}_{4} \mathrm{~N}\right]\left[\mathrm{Au}\left\{\mathrm{MoCp}(\mathrm{CO})_{3}\right\}_{2}\right],{ }^{119}$ itself obtained by the reaction of $\left[n-\mathrm{Bu}_{4} \mathrm{~N}\right]\left[\mathrm{AuBr}_{2}\right]$ with 2 equiv. of $\mathrm{Na}\left[\mathrm{MoCp}(\mathrm{CO})_{3}\right]$. These clusters form an interesting series of oligomers of the type $\left[\mathrm{M}\left\{\mathrm{MoCp}(\mathrm{CO})_{3}\right\}\right]_{\mathrm{n}}{ }^{\mathrm{n}-}(\mathrm{n}=3$ for $\mathrm{M}=\mathrm{Cu} ; \mathrm{n}=4$ for $\mathrm{M}=\mathrm{Ag}, \mathrm{Au})$ in which the group 11 metals are always in the M(I) oxidation state. Furthermore, the structural similarity between $\mathbf{2 9}$ or $\mathbf{3 0}$ and the cluster $\mathrm{Na}_{2}\left[\mathrm{Pd}_{4}\left\{\mathrm{MoCp}(\mathrm{CO})_{3}\right\}_{4}\right] \cdot 2 \mathrm{THF}$ (31) is noteworthy, ${ }^{120}$ although the electronic configuration of the Pd centres is different from $\mathrm{d}^{10}$. This $\mathrm{Pd}_{4} \mathrm{Mo}_{4}$ anionic octanuclear cluster was the first example of a $v_{2}$-square cluster where Pd has a formal oxidation state of $(+1 / 2) .{ }^{120}$ The redox reaction between $\left[\mathrm{Pd}_{4}(\mathrm{OAc})_{4}(\mathrm{CO})_{4}\right]$ (which contains a rectangular metal core) and a large excess of $\mathrm{Na}\left[\mathrm{MoCp}(\mathrm{CO})_{3}\right]$ in THF which afforded 31 also yielded the dinuclear complex $\left[\mathrm{CpMo}(\mathrm{CO})_{3}\right]_{2}$ and air-sensitive palladium-molybdenum complexes. 


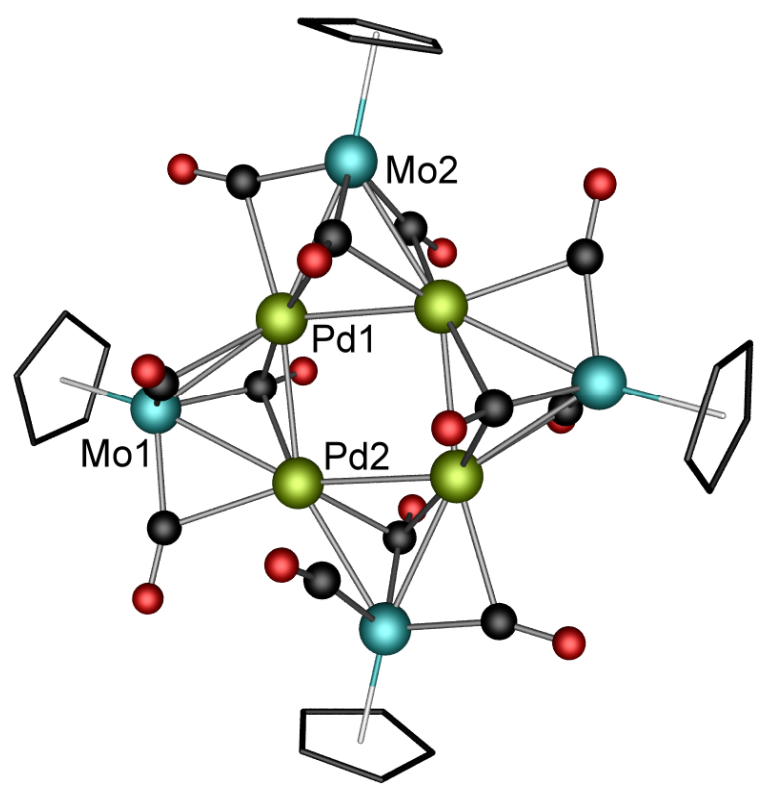

31

A planar $\mathrm{Au}_{4}$ unit was found in the neutral cluster $\left[\mathrm{Au}_{8} \mathrm{Mo}_{4}(\mathrm{CO})_{20}\left(\mathrm{PPh}_{3}\right)_{4}\right](\mathbf{3 2}){ }^{121}$ This complex was isolated in low yield $(<10 \%)$ from the reaction of $\left[\mathrm{AuCl}\left(\mathrm{PPh}_{3}\right)\right]$ with $\left[\mathrm{Mo}_{2}(\mathrm{CO})_{10}\right]_{2}^{-}$in acetonitrile at room temperature. The average $\mathrm{Au}-\mathrm{Au}$ separation is $2.77 \pm 0.02 \AA$ and the Au-Mo distances are $2.93 \pm 0.03 \AA$. The $\mathrm{Au}-\mathrm{Au}-\mathrm{Au}$ angles are around $90^{\circ}$.

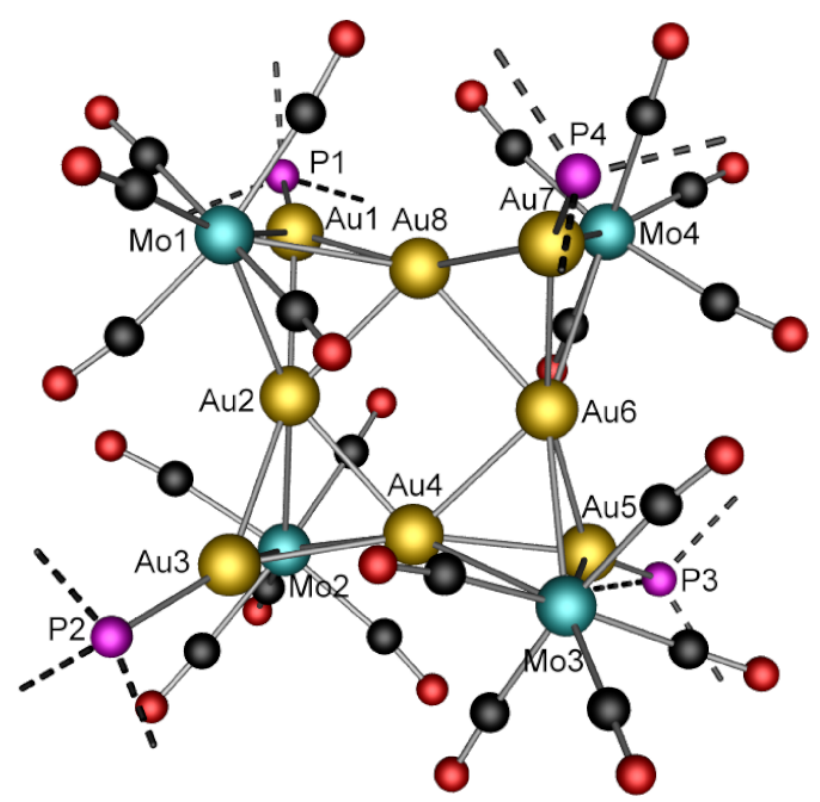

32

Phenyl groups have been omitted for clarity.

In 1995, Longoni and coll. reported the cluster $\left[\mathrm{Au}_{4}\left\{\mathrm{Fe}(\mathrm{CO})_{4}\right\}_{4}\right]^{4-}(\mathbf{3 3})^{122}$ which forms with 3 and 16 a nice homologous series of oligomeric clusters of the type $\left[\mathrm{M}\left\{\mathrm{Fe}(\mathrm{CO})_{4}\right\}\right]_{\mathrm{n}}{ }^{\mathrm{n}-}(\mathrm{n}$ 
$=3$ for $\mathrm{M}=\mathrm{Cu} ; \mathrm{n}=4$ for $\mathrm{M}=\mathrm{Ag}, \mathrm{Au})$. It is also closely related to $\mathbf{2 9}$ and $\mathbf{3 0}$ which belong to the family of clusters $\left[\mathrm{M}\left\{\mathrm{MoCp}(\mathrm{CO})_{3}\right\}\right]_{\mathrm{n}}{ }^{\mathrm{n}-}(\mathrm{n}=3$ for $\mathrm{M}=\mathrm{Cu} ; \mathrm{n}=4$ for $\mathrm{M}=\mathrm{Ag}, \mathrm{Au})$. Cluster 33 was isolated from the reaction in THF of $\left[\mathrm{Fe}(\mathrm{CO})_{4}\right]^{2-}$ with $\left[\mathrm{AuBr}_{2}\right]^{-}$in a molar ratio $1: 1$. Two structural modifications were characterized, consisting of a square (33A) or a rectangle of gold atoms (33B) whose edges are bridged by $\mathrm{Fe}(\mathrm{CO})_{4}$ groups. The $\mathrm{Au}(1)-\mathrm{Au}(2)$ and $\mathrm{Au}(2)-\mathrm{Au}\left(1^{\prime}\right)$ distances in $\mathbf{3 3 \mathbf { A }}$ and $\mathrm{Au}(3)-\mathrm{Au}(4)$ and $\mathrm{Au}(3)-\mathrm{Au}\left(4^{\prime}\right)$ in 33B are equal to 2.973(2) $\AA, 2.831(2) \AA, 2.932(2) \AA$ and 3.400(2) $\AA$, respectively. ${ }^{122}$

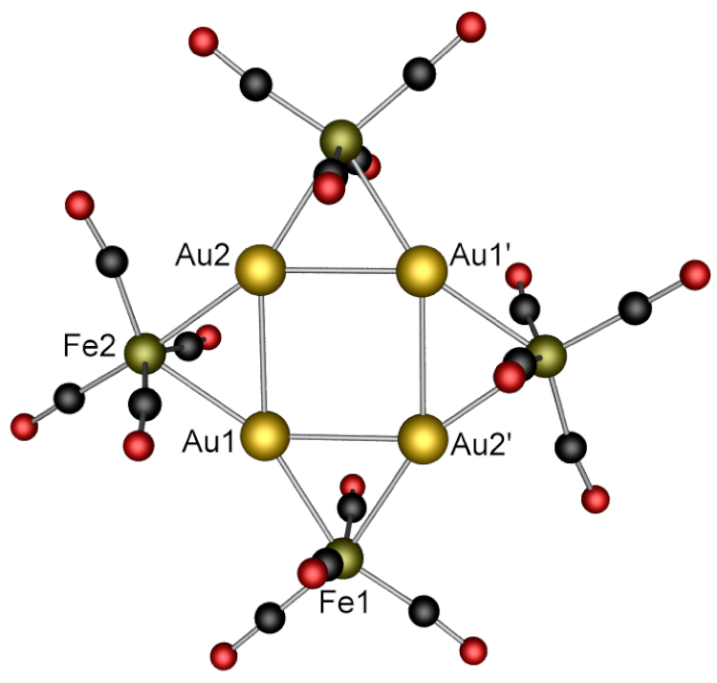

$33 \mathrm{~A}$

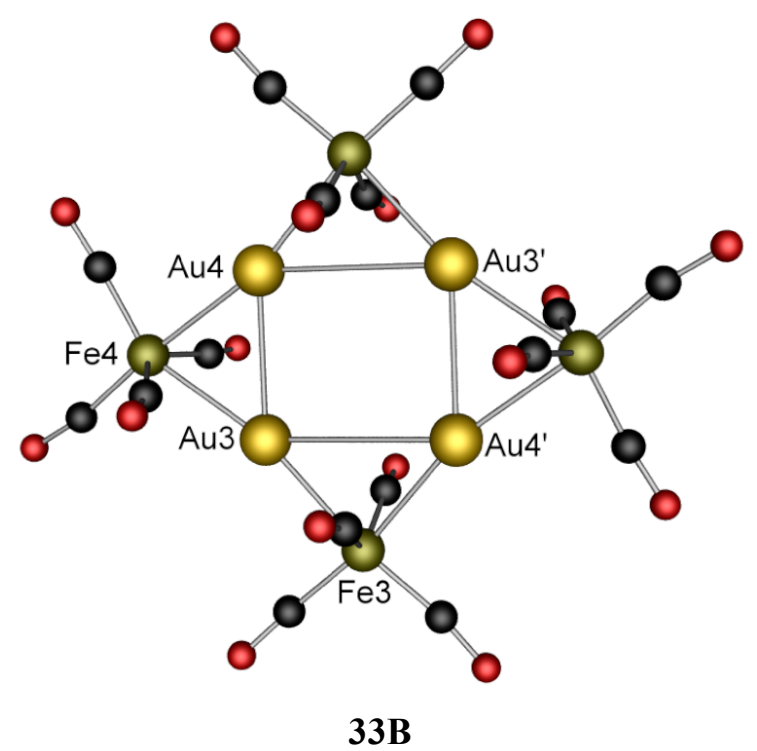

The neutral cluster $\left[\mathrm{Au}_{8}\left\{\mathrm{Fe}(\mathrm{CO})_{4}\right\}_{4}\left(\mathrm{P}^{\wedge} \mathrm{P}\right)_{2}\right](34)$ was isolated in good yields by condensation of the anion $\left[\mathrm{Au}_{3}\left\{\mathrm{Fe}(\mathrm{CO})_{4}\right\}_{2}\left(\mathrm{P}^{\wedge} \mathrm{P}\right)\right]^{-}$with $\left[\mathrm{AuCl}\left(\mathrm{SEt}_{2}\right)\right] .{ }^{123}$ The $\mathrm{Au}-\mathrm{Au}$ distances in the gold core are in the range 2.737(2)-2.772(2) $\AA$ and the mean Au-Au distance in the central square is $2.7485 \AA$. The successful synthesis of this cluster via the condensation reaction shown below (Scheme 2) suggested the possible synthesis of related clusters $\left[\mathrm{Au}_{6} \mathrm{M}_{2}\left\{\mathrm{Fe}(\mathrm{CO})_{4}\right\}_{4}\left(\mathrm{P}^{\wedge} \mathrm{P}\right)_{2}\right](\mathrm{M}=\mathrm{Cu}, \mathrm{Ag})$ upon replacement of $\left[\mathrm{AuCl}\left(\mathrm{SEt}_{2}\right)\right]$ with $\mathrm{CuCl}$ or $\mathrm{AgNO}_{3}$. To our knowledge, only the $\left[\mathrm{Au}_{6} \mathrm{Cu}_{2}\left\{\mathrm{Fe}(\mathrm{CO})_{4}\right\}_{4}\left(\mathrm{P}^{\wedge} \mathrm{P}\right)_{2}\right]$ derivative has been described in the literature. ${ }^{123}$ 

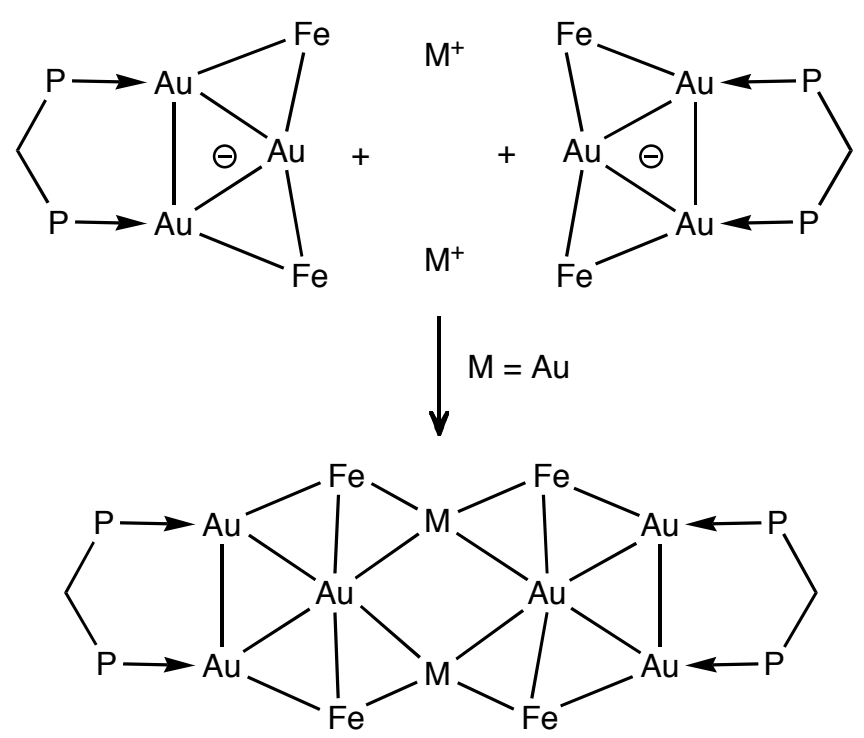

Scheme 2. Synthesis of $\mathbf{3 4}$ by condensation reaction. ${ }^{123}$

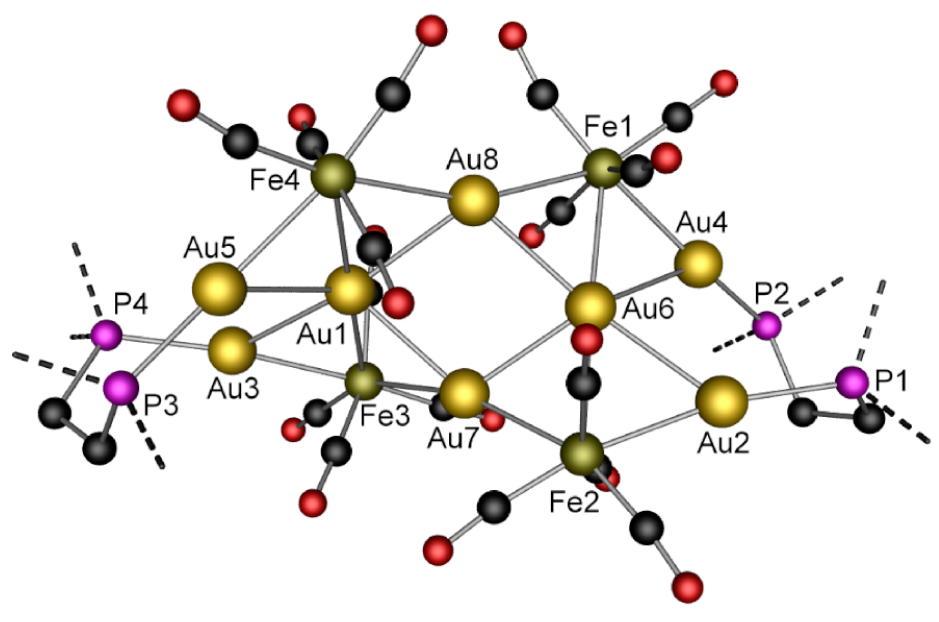

34

Phenyl groups have been omitted for clarity.

In view of the structural similarities between the gold core of the mixed-metal clusters discussed above and some homometallic gold clusters, it is interesting to compare their Au$\mathrm{Au}$ distances. In the triangular cluster $\left[\mathrm{Au}_{3}\left\{\mu_{2}-(p-\text { tol }) \mathrm{N}=\mathrm{COEt}\right\}_{3}\right](\mathbf{3 5})^{124}$ and the gold square found in $\left[\mathrm{Au}_{4}\left\{\mu_{2}-\mathrm{PhNC}(\mathrm{Ph}) \mathrm{NPh}\right\}_{4}\right](\mathbf{3 6}),{ }^{125}$ the $\mathrm{Au}-\mathrm{Au}$ distances in the range 3.2790(9)3.3368(9) $\AA$ and 2.925(2)- 2.982(2) $\AA$ for 35 and 36, respectively, are similar to those in the heterometallic clusters $\{\mathrm{Au}[\mathrm{m}]\}_{4}$ discussed above. The gold atoms in $\mathbf{3 6}$ form a distorted square $\left(\mathrm{Au}-\mathrm{Au}-\mathrm{Au}=82-97^{\circ}\right)$ and the $\mathrm{N}-\mathrm{Au}-\mathrm{N}$ angles of $170^{\circ}$ show a deviation from linearity consistent with $\mathrm{Au} \cdots \mathrm{Au}$ interactions. 


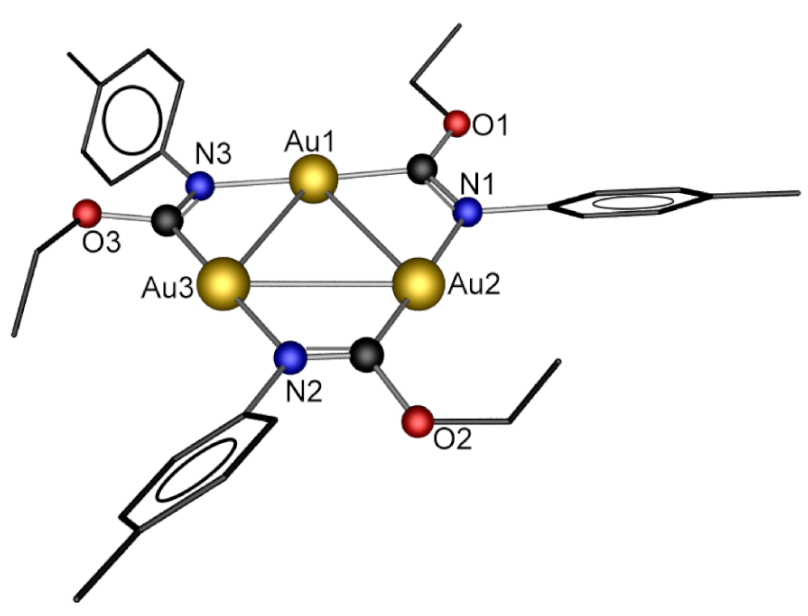

35

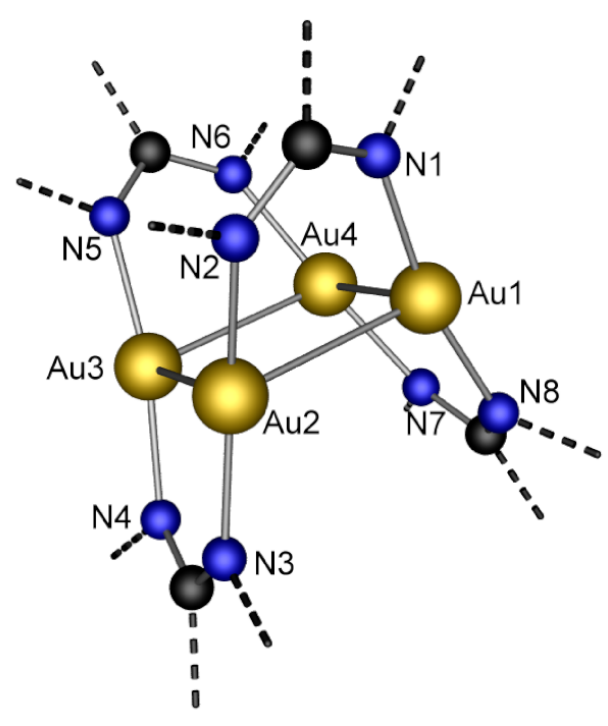

36

Phenyl groups in $\mathbf{3 6}$ have been omitted for clarity.

\section{Intramolecular heterometallic $\mathbf{d}^{\mathbf{1 0}}-\mathrm{d}^{\mathbf{1 0}}$ interactions in heterometallic clusters.}

The number of mixed-metal complexes and clusters containing at least two chemically different $\mathrm{d}^{10}$ ions susceptible to interact which each other, in addition to another metal, is still limited but rapidly increasing. It is therefore interesting to examine the consequences of these interactions on the structure and properties of the complexes and compare them with those in which the $\mathrm{d}^{10}$ ions are the same. Heterobimetallic complexes containing two metals of the group 11 have been recently shown to possess interesting luminescence properties. ${ }^{85,111,126-138}$ Examples of mixed-metal clusters containing two different group 11 metals and another metal remain rare. We have recently examined ways to prepare such trimetallic complexes in order to compare them with the related bimetallic compounds.

\section{1. $\mathrm{Cu}-\mathrm{Ag}$ Interactions}

Reaction of the salt $\left[\mathrm{N}\left(\mathrm{PPh}_{3}\right)_{2}\right]_{2}\left[\mathrm{Ru}_{4}(\mu-\mathrm{H})_{2}(\mathrm{CO})_{12}\right]$ with 1 equiv. of $\left[\mathrm{CuCl}\left(\mathrm{PPh}_{3}\right)\right]$ and 1 equiv. of $\left[\mathrm{AgI}\left(\mathrm{PPh}_{3}\right)\right]$ in dichloromethane, in the presence of $\mathrm{TIPF}_{6}$, afforded red microcrystals of the trimetallic cluster $\left[\mathrm{CuAgRu}_{4}\left(\mu_{3}-\mathrm{H}\right)_{2}(\mathrm{CO})_{12}\left(\mathrm{PPh}_{3}\right)_{2}\right](37)$ in $c$. $35-45 \%$ yield. ${ }^{139,140}$ The metal skeleton of $\mathbf{3 7}$ consists of a tetrahedron of ruthenium atoms with the $\mathrm{Ru}(1) \mathrm{Ru}(3) \mathrm{Ru}(4)$ face capped by a $\mathrm{Cu}\left(\mathrm{PPh}_{3}\right)$ moiety and the $\mathrm{Cu}(1) \mathrm{Ru}(3) \mathrm{Ru}(4)$ face of the $\mathrm{CuRu}_{3}$ tetrahedron thus formed further capped by a $\mathrm{Ag}\left(\mathrm{PPh}_{3}\right)$ unit to give a capped trigonal bipyramidal metal core geometry. A comparison of the interatomic distances between $\mathbf{3 7}$ and the analogous bimetallic copper and silver complexes shows that the $\mathrm{Cu}-\mathrm{Ag}$ separation 
$[2.764(1) \AA]$ is intermediate between the $\mathrm{Cu}-\mathrm{Cu}[2.699(2) \AA]$ and the Ag-Ag separation [2.857(1) $\AA$.

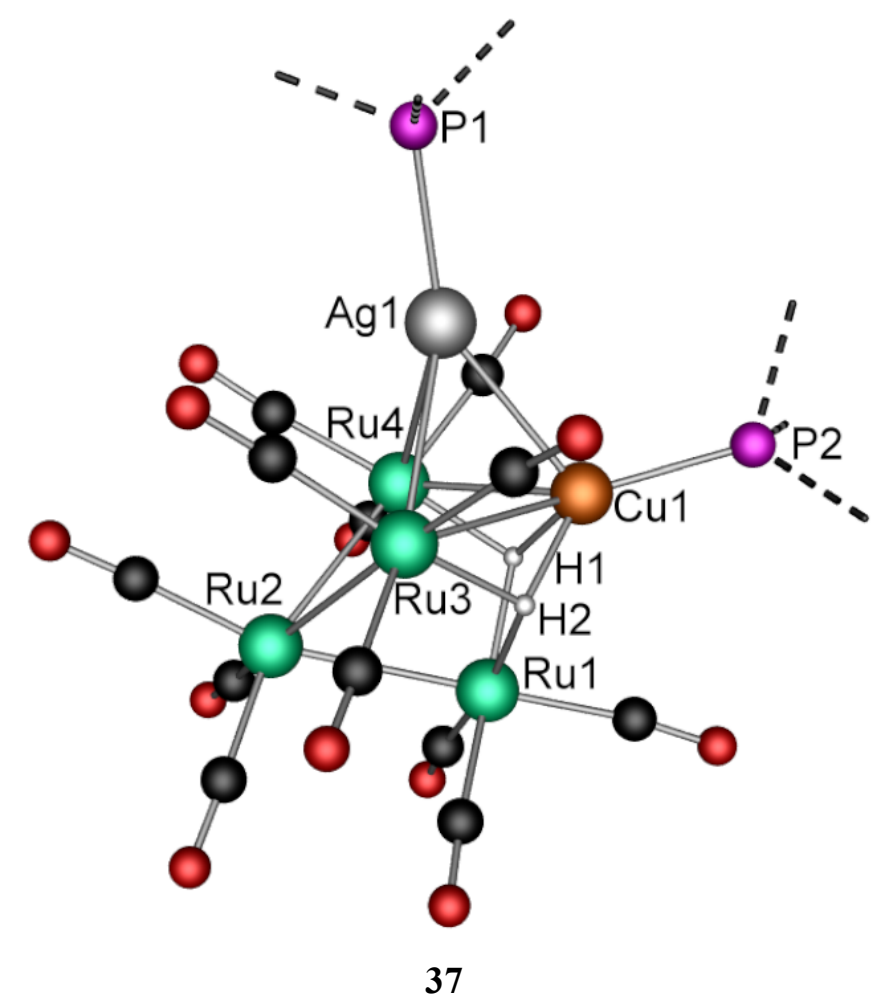

The phenyl groups have been omitted for clarity.

The structure of $\left[\mathrm{CuAg}_{3}\left\{\mathrm{MoCp}\left(\mathrm{CO}_{3}\right\}_{4}\right]\right.$ (38) contains a central square metal core formed by three silver(I) and one copper(I) ions, inscribed within a molybdenum square since each edge of the coinage metal square is bridged by a $\mathrm{MoCp}(\mathrm{CO})_{3}$ fragment. This molecule is the first trimetallic cluster with such a $v_{2}$-square geometry. ${ }^{119}$ The $\mathrm{Cu}$ - $\mathrm{Ag}$ distances in $\mathbf{3 8}$ are in the range 2.734(1)-2.814(1) $\AA$ and are clearly shorter than the sum of the van der Waals radii for copper and silver (3.12 $\AA$ ) or to the value of 2.9931(12) $\AA$ found in a dinuclear Ag$\mathrm{Au}$ complex containing bridging ligands. ${ }^{141}$ They are even comparable to the sum of the covalent radii of $2.77 \AA$ for copper and silver. ${ }^{99}$ The $\mathrm{Cu}-\mathrm{Ag} \mathrm{d} \mathrm{d}^{10}-\mathrm{d}^{10}$ distances are intermediate between those in the analogous copper $\left[\mathrm{Cu}_{3}\left\{\mathrm{MoCp}\left(\mathrm{CO}_{3}\right\}_{3}\right]\right.$ (mean value of $\mathrm{Cu}-\mathrm{Cu}: 2.627(8)$ $\AA$ ) and silver complexes $\left[\mathrm{Ag}_{4}\left\{\mathrm{MoCp}\left(\mathrm{CO}_{3}\right\}_{4}\right]\right.$ (mean value of Ag-Ag: 2.8699(9) $\AA$ ). The AgAg distances in 38, in the range 2.9093(8)-2.9351(11) $\AA$, are longer than the Ag-Ag distances in $\left[\mathrm{Ag}_{4}\left\{\mathrm{MoCp}\left(\mathrm{CO}_{3}\right\}_{4}\right]\right.$. The Ag1-Cu1-Ag3, Cu1-Ag3-Ag2, Ag3-Ag2-Ag1 and the Ag2-Ag1$\mathrm{Cu} 1$ angles of $83.94(3)^{\circ}, 97.22(2)^{\circ}, 78.83(2)^{\circ}$ and $99.68(3)^{\circ}$, respectively, are indicative of distorsions of the metal core away from planarity. 


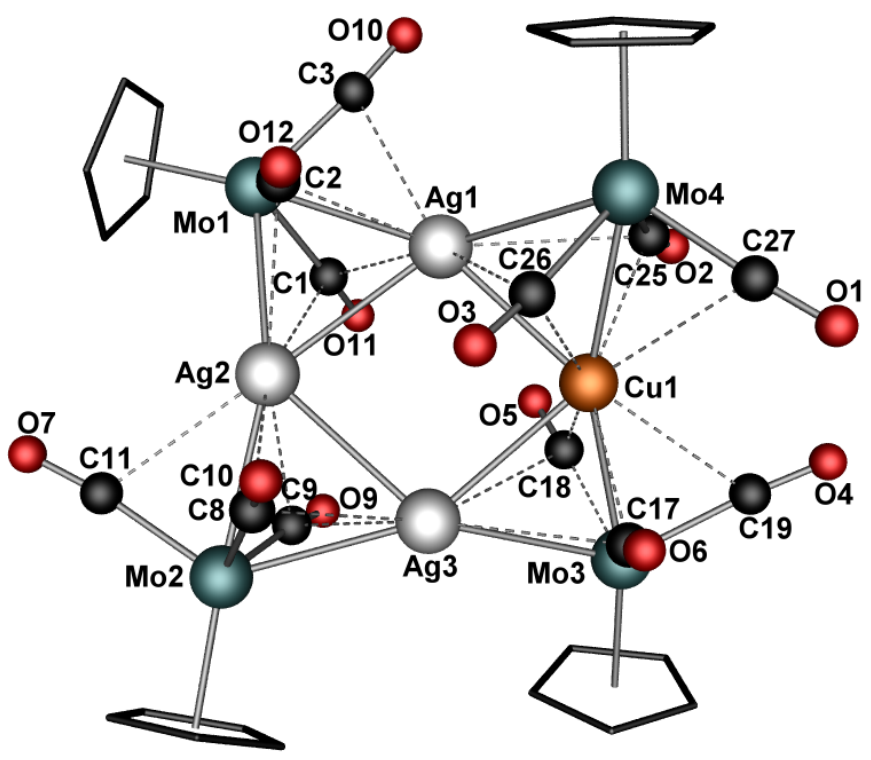

38

Reaction of $\mathrm{RNHC}(\mathrm{S}) \mathrm{PPh}_{2} \mathrm{NPPh}_{2} \mathrm{C}(\mathrm{S}) \mathrm{NR}$ (HRSNS; R = Me, Et) with $\mathrm{Cu}(\mathrm{I}), \mathrm{Ag}(\mathrm{I})$ or $\mathrm{Au}(\mathrm{I})$ salts followed by deprotonation afforded zwitterionic complexes of general formula $[\mathrm{M}(\mathrm{RSNS})](\mathrm{M}=\mathrm{Cu}, \mathrm{Ag}, \mathrm{Au}) .{ }^{142}$ The complexes [Cu(RSNS)] and $[\mathrm{Ag}(\mathrm{RSNS})]$ were used as building blocks for the assembly of dicationic, pentanuclear multi-zwitterionic $\mathrm{Cu}_{5}, \mathrm{Cu}_{3} \mathrm{Ag}_{2}$ (39) and $\mathrm{Ag}_{5}$ clusters of the general formula $\left[\mathrm{M}_{2}^{\prime}\{\mathrm{M}(\mathrm{RSNS})\}_{3}\right]^{2+}\left(\mathrm{M}=\mathrm{Cu}, \mathrm{M}^{\prime}=\mathrm{Cu}, \mathrm{Ag} ; \mathrm{M}\right.$ $\left.=\mathrm{M}^{\prime}=\mathrm{Ag}\right){ }^{142}$ The reaction of $[\mathrm{Ag}(\mathrm{EtSNS})]$ with $\left[\mathrm{Cu}(\mathrm{NCMe})_{4}\right] \mathrm{PF}_{6}$ in a $3: 2$ ratio did not afford the expected complex $\left[\mathrm{Cu}_{2}\{\mathrm{Ag}(\mathrm{EtSNS})\}_{3}\right]\left[\mathrm{PF}_{6}\right]_{2}$ but rather a mixture of species, in which $\left[\mathrm{Ag}_{2}\{\mathrm{Cu}(\mathrm{EtSNS})\}_{3}\right]^{2+}$ was the major product. In 39, the average $\mathrm{Ag}-\mathrm{Cu}$ and $\mathrm{Ag}-\mathrm{Ag}$ bond lengths are 2.899(6) $\AA$ and 3.149(7) $\AA$, and the average Ag-Cu-Ag and $\mathrm{Cu}-\mathrm{Ag}-\mathrm{Cu}$ angles are $65.8(2)^{\circ}$ and $94.8(1)^{\circ}$, respectively.
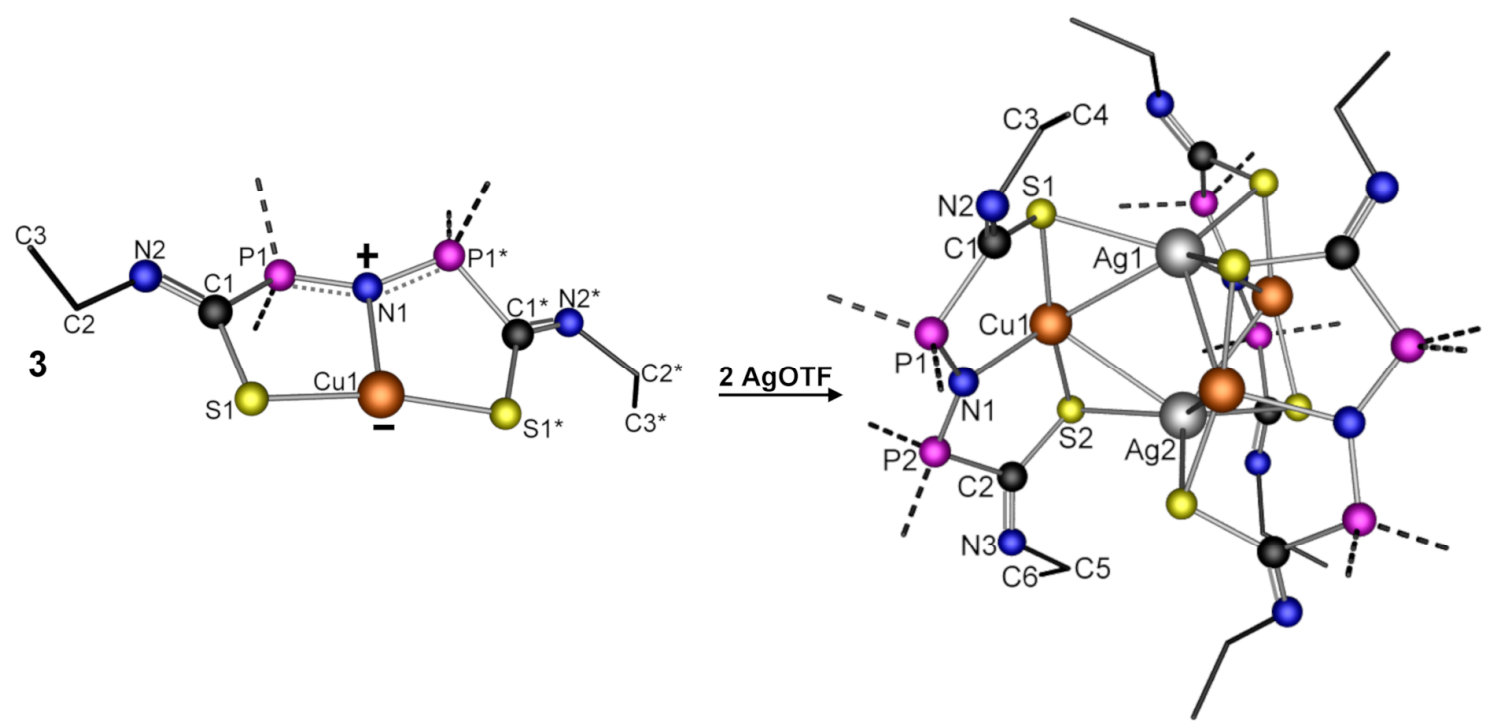

Phenyl groups have been omitted for clarity. 
"Wrapping" the $\left[\mathrm{Au}_{6} \mathrm{Cu}_{6}\left(\mathrm{C}_{2} \mathrm{Ph}\right)_{12}\right]$ cluster in a $\left[\mathrm{Au}_{3}(\text { diphosphine })_{3}\right]^{3+}$ "belt" was found to increase its stability, particularly under irradiation. Its luminescence is much more intense than that of the corresponding homometallic compounds and was attributed to the presence of the $\mathrm{Cu}_{6} \mathrm{Au}_{6}$ cluster core. ${ }^{143}$

\section{2. $\mathrm{Cu}-\mathrm{Au}$ Interactions}

Specific properties may be associated with the presence of heterometallic $\mathrm{d}^{10}-\mathrm{d}^{10}$ interactions, as shown recently with a trinuclear, $\mathrm{Cu}-\mathrm{Au}-\mathrm{Cu}$ chain complex which functions as a luminescent vapochromic sensor, ${ }^{144}$ or in $\mathrm{Cu}(\mathrm{I})$ halide butterfly dimers interacting with a $\mathrm{Au}(\mathrm{I})$ cationic dicarbene unit. ${ }^{128}$ In the complex $\left[\mathrm{Au}_{3}\left(\mu_{3}-\mathrm{S}\right) \mathrm{Cu}\left(\mu-\mathrm{PPh}_{2} \mathrm{py}\right)_{3}\right]\left(\mathrm{BF}_{4}\right)_{2}\left(\mathrm{PPh}_{2} \mathrm{py}=\right.$ diphenylphosphine-2-pyridine), the $\mathrm{Cu}$-Au contacts within the tetrahedral metal core were found in the range 2.9000(13)-2.9871(14) $\AA$. A coordination isomer was also characterized in which two monocationic $\mathrm{Au}_{3} \mathrm{~S}$ units bridge two $\mathrm{Cu}(\mathrm{I})$ ions through the pyridine groups. There is only one $\mathrm{Cu}-\mathrm{Au}$ bonding interaction in this compound and its value of 2.7954(9) $\AA$ is shorter than in the other isomer. ${ }^{115}$

The trimetallic, hexanuclear clusters $\left[\mathrm{MM}^{\prime} \mathrm{Ru}_{4}\left(\mu_{3}-\mathrm{H}\right)_{2}\left\{\mu-\mathrm{Ph}_{2} \mathrm{P}\left(\mathrm{CH}_{2}\right)_{\mathrm{n}} \mathrm{PPh}_{2}\right\}(\mathrm{CO})_{12}\right]$ $\left[\mathrm{M}=\mathrm{Cu}, \mathrm{M}^{\prime}=\mathrm{Ag}\right.$ or $\left.\mathrm{Au} ; \mathrm{M}=\mathrm{Ag}, \mathrm{M}^{\prime}=\mathrm{Au}\right]$ were synthesized for comparison with the analogous bimetallic clusters. ${ }^{145}$ The molecular structure of $\left[\mathrm{AuCuRu}_{4}\left(\mu_{3}-\mathrm{H}\right)_{2}\{\mu-\right.$ $\left.\left.\mathrm{Ph}_{2} \mathrm{P}\left(\mathrm{CH}_{2}\right)_{2} \mathrm{PPh}_{2}\right\}(\mathrm{CO})_{12}\right](40)$ consists of a tetrahedron of ruthenium atoms of which the $\mathrm{Ru}(1) \mathrm{Ru}(3) \mathrm{Ru}(4)$ face is capped by a copper atom. One of the $\mathrm{CuRu}_{3}$ faces of the tetrahedron thus formed is further capped by a gold atom, to give an overall capped trigonal bipyramidal metal core geometry. The $\mathrm{Cu}-\mathrm{Au}$ distance in $\mathbf{4 0}$ of 2.614(2) $\AA$ suggests the occurrence of direct metal-metal interactions. Similarly, the mixed metal cluster $\left[\mathrm{MM}^{\prime} \mathrm{Ru}_{4} \mathrm{H}_{2}(\mu-\right.$ $\left.\operatorname{dppf})(\mathrm{CO})_{12}\right]\left[\mathrm{M}=\mathrm{Cu}, \mathrm{M}^{\prime}=\mathrm{Au}\right.$; dppf $\left.=\mathrm{Fe}\left(\eta^{5}-\mathrm{C}_{5} \mathrm{H}_{4} \mathrm{PPh}_{2}\right)_{2}\right](\mathbf{4 1})^{146}$ was compared to the analogous bimetallic clusters [ $\mathrm{MM}^{\prime} \mathrm{Ru}_{4} \mathrm{H}_{2}(\mu$-dppf $\left.)(\mathrm{CO})_{12}\right]\left[\mathrm{M}=\mathrm{M}^{\prime}=\mathrm{Cu}, \mathrm{Ag}\right.$ or $\left.\mathrm{Au}\right]$. The metal skeleton of $\mathbf{4 1}$ is similar to that of $\mathbf{4 0}$. The $\mathrm{Cu}-\mathrm{Au}$ distance in $\mathbf{4 1}$ [2.641(1) $\AA$ ] is intermediate between the $\mathrm{Cu}-\mathrm{Cu}$ and $\mathrm{Au}-\mathrm{Au}$ distances in the bimetallic copper and gold analogues [2.528(2) $\AA$ and 2.901(1) A, respectively]. 


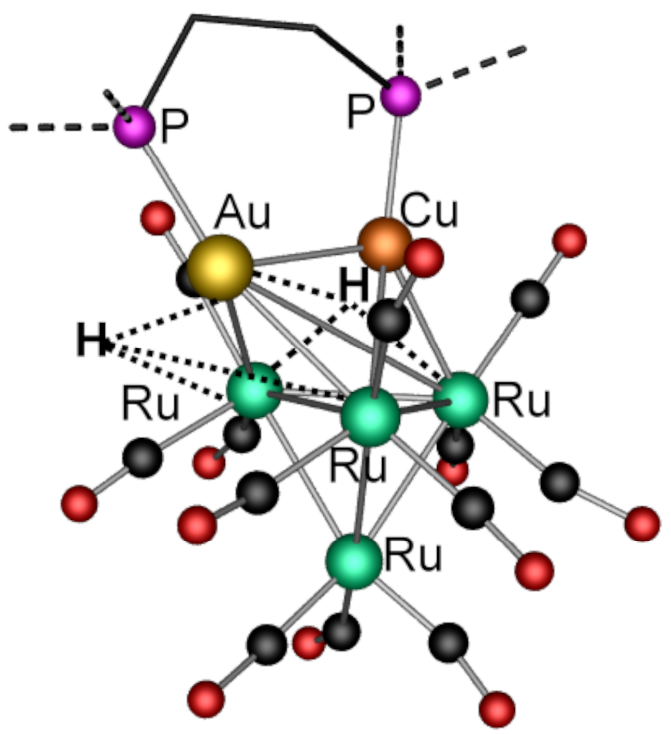

40

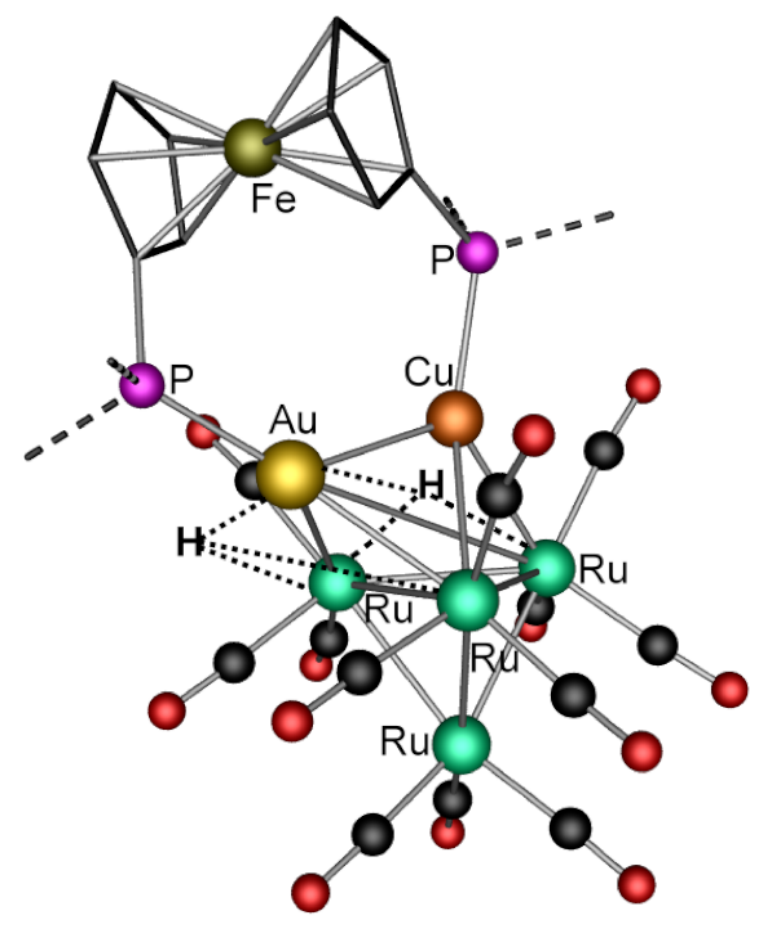

41

The cluster $\left[\mathrm{Cu}_{2} \mathrm{Au}_{6}\left\{\mathrm{Fe}(\mathrm{CO})_{4}\right\}_{4}(\mathrm{dppe})_{2}\right]$ (42) contains a mixed $\mathrm{Cu}_{2} \mathrm{Au}_{2}$ square. ${ }^{123}$ The average distance between copper and gold is $2.558 \AA$, which is shorter than the Au-Au distances in the gold analogue 34 (range 2.737(2)-2.772(2) $\AA$ ). ${ }^{123}$

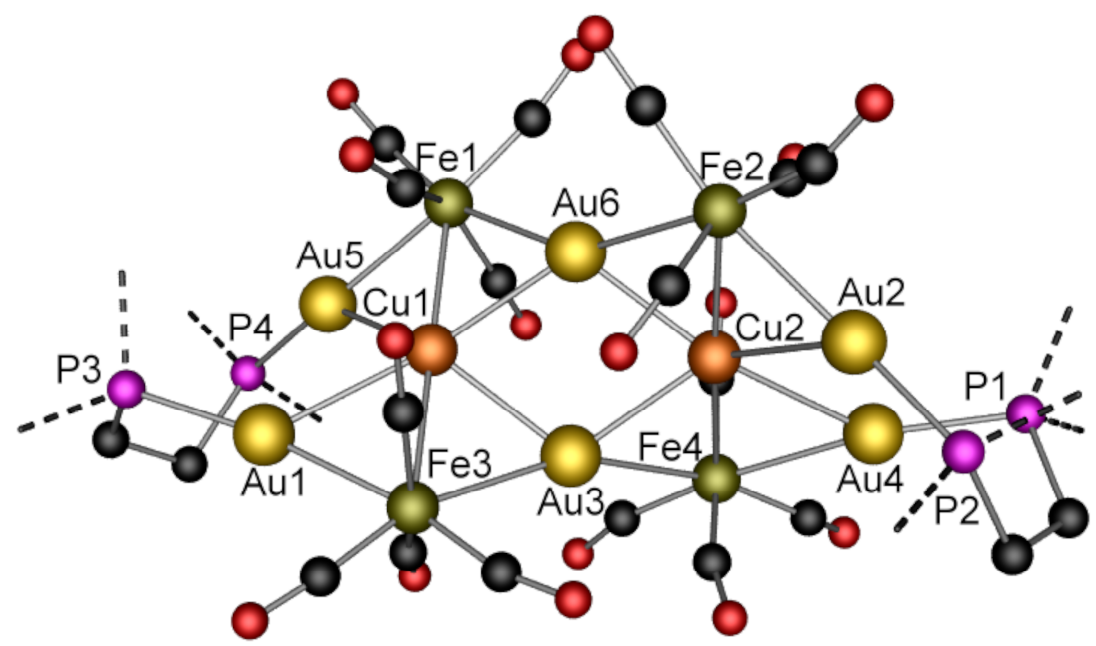

42

In $\left[\mathrm{CuAu}_{3}\left\{\mathrm{MoCp}\left(\mathrm{CO}_{3}\right\}_{4}\right]\right.$ (43), which was one of the first trimetallic cluster with $\mathbf{3 8}$ to have a $v_{2}$-square structure, the central metal square is formed by two $\mathrm{Au}(\mathrm{I})$ centres and the other two opposite positions contain a mixture of gold and copper. The best fit for the structure refinement was obtained when assuming a 80:20 Cu/Au occupation for one of these two sites, 20:80 Cu/Au for the other. Each edge of the square is bridged by a $\mathrm{MoCp}(\mathrm{CO})_{3}$ 
metalloligand. The molybdenum atoms form a distorted $\mathrm{Mo}_{4}$ square and are not coplanar with the gold and copper atoms, as a result of a slight tetrahedral distortion. The distances between the group 11 metals are in the range 2.6657(15)- 2.9037(9) $\AA$ and are much shorter than the sum of the van der Waals radii (3.06 $\AA$ ). They are even comparable to the sum of the covalent radii proposed for $\mathrm{Cu}$ and $\mathrm{Au}(2.68 \AA) .{ }^{99}$

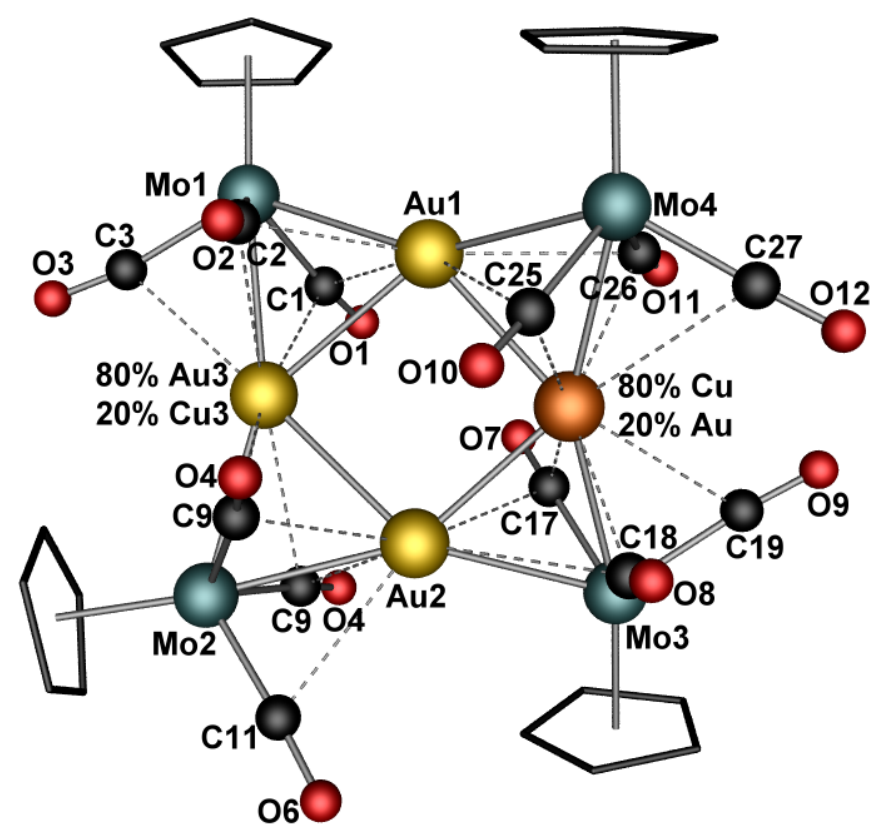

The reaction of $\left[\left(\mathrm{RC}_{2} \mathrm{Au}\right) \mathrm{PPh}_{2} \mathrm{C}_{6} \mathrm{H}_{4} \mathrm{PPh}_{2}\left(\mathrm{AuC}_{2} \mathrm{R}\right)\right]\left(\mathrm{R}=\mathrm{Fc}\right.$ or $\left.\mathrm{C}_{6} \mathrm{H}_{4} \mathrm{Fc}\right)$ with $\left[\mathrm{Cu}(\mathrm{NCMe})_{4}\right] \mathrm{PF}_{6}$ afforded the heterometallic complexes $\left[\left\{\mathrm{Au}_{3} \mathrm{Cu}_{2}\left(\mathrm{C}_{2} \mathrm{Ph}\right)_{6}\right\} \mathrm{Au}_{3}\left(\mathrm{PR}_{2} \mathrm{C}_{6} \mathrm{H}_{4} \mathrm{PR}_{2}\right)_{3}\right]\left[\mathrm{PF}_{6}\right]_{2}$ (44). ${ }^{130}$ The average $\mathrm{Cu}-\mathrm{Au}$ distance of $2.853 \AA$ is in the range found for the other gold-copper complexes with direct $\mathrm{Au}-\mathrm{Cu}$ bonding.

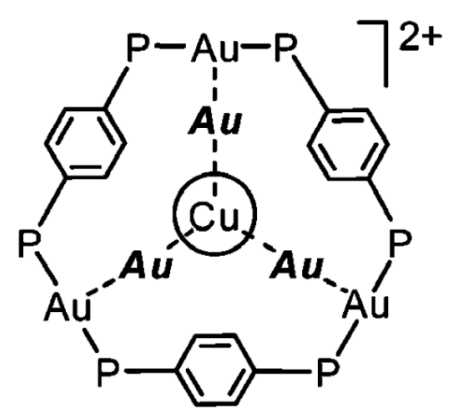

44

(Reprinted with permission from ref. 130.

Copyright American Chemical Society) 
A luminescent alkynyl $\mathrm{Cu}_{2} \mathrm{Au}_{4}$ cluster of $C_{2}$ symmetry was obtained by reaction of an alkynyldigold(I) complex with $\left[\mathrm{Cu}(\mathrm{NCMe})_{4}\right]^{+}$and its crystal structure revealed that the weak $\mathrm{Au} \cdots \mathrm{Au}$ interaction present in the precursor complex was replaced by two $\mathrm{Cu} \cdots \mathrm{Au}$ contacts of $2.8524(16) \AA^{147}$ In the heterobimetallic $\mathrm{Cu}(\mathrm{I})-\mathrm{Au}(\mathrm{I})$ alkynyl cluster $(45),{ }^{148}$ the intramolecular $\mathrm{Cu} \cdots \mathrm{Au}$ distances are in the range 2.743(1)-2.980(1) $\AA$, which indicates the possible occurrence of $\mathrm{Cu}^{\cdots} \mathrm{Au}$ interactions. The homometallic $\mathrm{Cu} \cdots \mathrm{Cu}$ and $\mathrm{Au} \cdots \mathrm{Au}$ separations of $4.153 \AA$ and $3.451-3.476 \AA$ are two long to represent significant coppercopper or gold-gold interactions. The complex was prepared by a modification of previous literature procedures. ${ }^{149}$

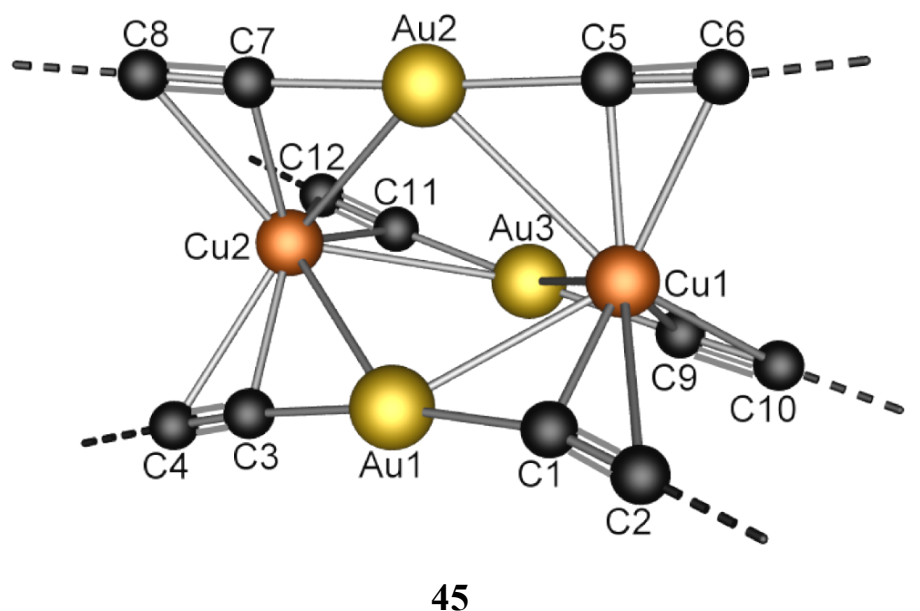

The phenyl groups have been omitted for clarity.

\subsection{Ag-Au Interactions}

In the complex $\left[\mathrm{Au}_{3}\left(\mu_{3}-\mathrm{O}\right) \mathrm{Ag}\left(\mu-\mathrm{PPh}_{2} \mathrm{py}\right)_{3}\right]\left(\mathrm{BF}_{4}\right)_{2}\left(\mathrm{PPh}_{2}\right.$ py = diphenylphosphine-2-pyridine), which exhibits extremely bright luminescence in the solid-state at room-temperature, the Ag$\mathrm{Au}$ contacts within the tetrahedral core are in the range $2.8985(5)-2.9690(5) \AA .{ }^{114}$ A square pyramidal $\mathrm{Ag}_{4} \mathrm{Au}$ cluster has been characterized in which the apical $\mathrm{Au}(\mathrm{I})$ centre is connected to two basal $\mathrm{Ag}(\mathrm{I})$ centres via 3c-2e aryl bridges but this did not affect significantly the Ag$\mathrm{Au}$ distances, which were in the range 2.9019(6)-3.0134(6) $\AA .^{104}$ A helical coordination polymer containing pyridine-substituted N-heterocyclic carbene ligands as supports for $\mathrm{Ag}(\mathrm{I})-\mathrm{Au}(\mathrm{I})$ interactions of 2.8359(4) and 2.9042(4) $\AA$ has been characterized. ${ }^{135}$ A complex analogous to 44 containing $\mathrm{Ag}(\mathrm{I})$ in place of $\mathrm{Cu}(\mathrm{I})$ displays $\mathrm{Ag}-\mathrm{Au}$ separations ranging from 2.9194(13) to 3.0121(13) Å..$^{150}$

Trimetallic clusters containing silver, gold and another metal are rare. An example was encountered with 20 in which the Ag-Au separations range 2.767(2)-2.793(2) $\AA .{ }^{109}$ Two 
pairs of diastereomeric tetrahedral clusters $\left[\mathrm{Re}_{2}\left(\mathrm{MPPh}_{3}\right)\left(\mathrm{M}^{\prime} \mathrm{PPh}_{3}\right)\left(\mu-\mathrm{PCy}_{2}\right)(\mathrm{CO})_{7}\right]$ with mixed coinage metals $\left(\mathrm{M}=\mathrm{Au}, \mathrm{M}^{\prime}=\mathrm{Cu}(\mathbf{4 6})\right.$ or $\left.\mathrm{Ag}(\mathbf{4 7})\right)$ have been synthesised. ${ }^{151} \mathrm{The} \mathrm{Cu}-\mathrm{Au}$ and Ag-Au distances are 2.584(2) $\AA$ and 2.7026(18) $\AA$, respectively.

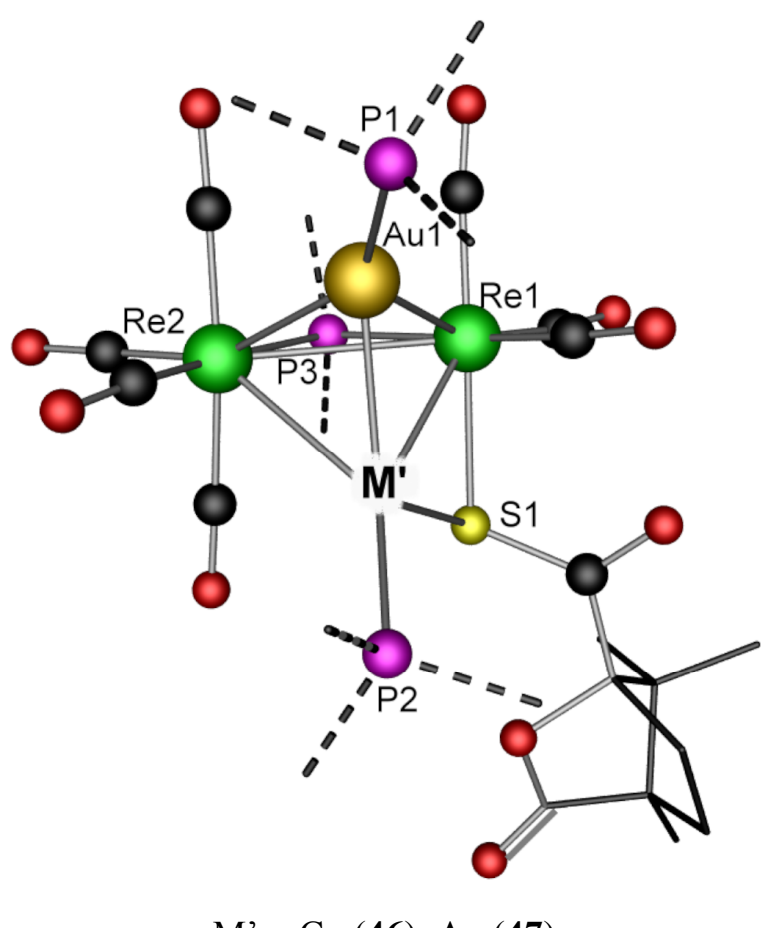

$\mathrm{M}^{\prime}=\mathrm{Cu}(46), \mathrm{Ag}(47)$

The terminal phenyl and cyclohexyl groups have been omitted for clarity.

Comparisons with the metallophilic $\mathrm{Ag} \cdots \mathrm{Au}$ contacts in (trimethylphosphine)silver(I) and -gold(I) phenylethynyl complexes can be made. ${ }^{152}$ The structure of the anionic cluster in $\left[\mathrm{Ag}\left(\mathrm{PMe}_{3}\right)_{2}\right]^{+}\left[\mathrm{Ag}_{2} \mathrm{Au}_{3}(\mathrm{C} \equiv \mathrm{CPh})_{6}\right]^{-}(\mathbf{4 8})$ has an idealized $D_{3 h}$ symmetry with the gold atoms of three collinear $\mathrm{PhC} \equiv \mathrm{CAuC} \equiv \mathrm{CPh}$ anions forming an equilateral triangle. The silver atoms are also in close contact with the gold atoms, with distances ranging from 2.854(2) to 3.039(1) $\AA$, which clearly represent metallophilic interactions and are comparable with the sum of the covalent radii of $2.81 \AA$ for $\mathrm{Ag}$ and $\mathrm{Au} .{ }^{99}$ The $\mathrm{Ag}_{2} \mathrm{Au}_{3}$ trigonal-bipyramidal metal core has six axial-equatorial $\mathrm{Ag}$-Au bonds, but the equatorial-equatorial $\mathrm{Au}-\mathrm{Au}$ contacts (3.95 $\AA$ average) are too long to represent significant metallophilic interactions. This type of pentanuclear anion has been characterised previously by Abu-Salah who prepared several complexes of formula $\left[\mathrm{M}_{2} \mathrm{M}_{3}{ }_{3}(\mathrm{C} \equiv \mathrm{CR})_{6}\right]^{-}\left(\mathrm{M}, \mathrm{M}^{\prime}=\mathrm{Cu}\right.$, $\mathrm{Ag}, \mathrm{Au}){ }^{149,153}$ 


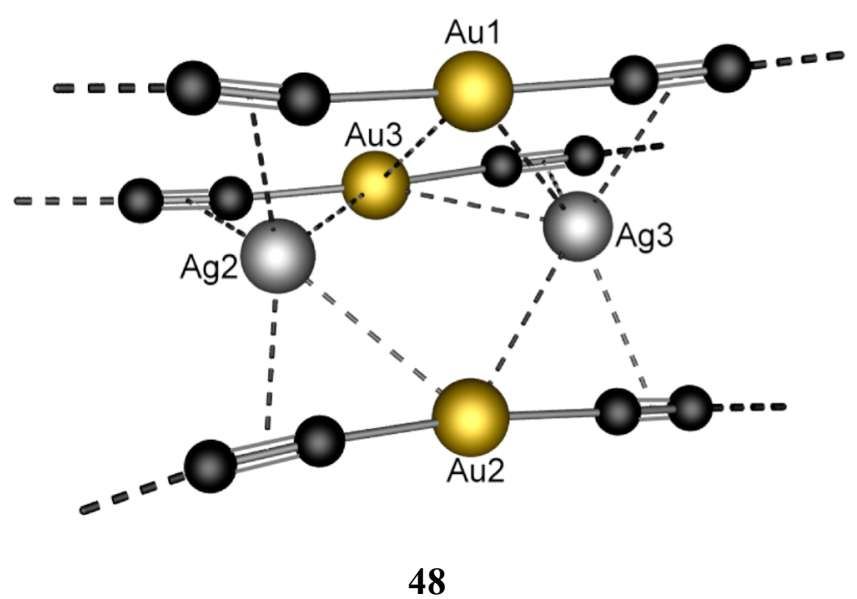

The terminal phenyl groups have been omitted for clarity.

The crystal structure of the complex $\left[\mathrm{AgAu}_{4}\left(\mathrm{CH}_{2} \mathrm{SiMe}_{3}\right)_{4}(\mu-\mathrm{dppm})_{2}\right] \mathrm{SO}_{3} \mathrm{CF}_{3}(\mathbf{4 9})^{154}$ shows the presence of a silver(I) centre solely bonded to four gold atoms in a distorted tetrahedral environment. The silver-gold and the silver-silver distances are in the range 2.7179(13)-2.7822(13), 3.2170(9)-3.2773(12) Å, respectively.

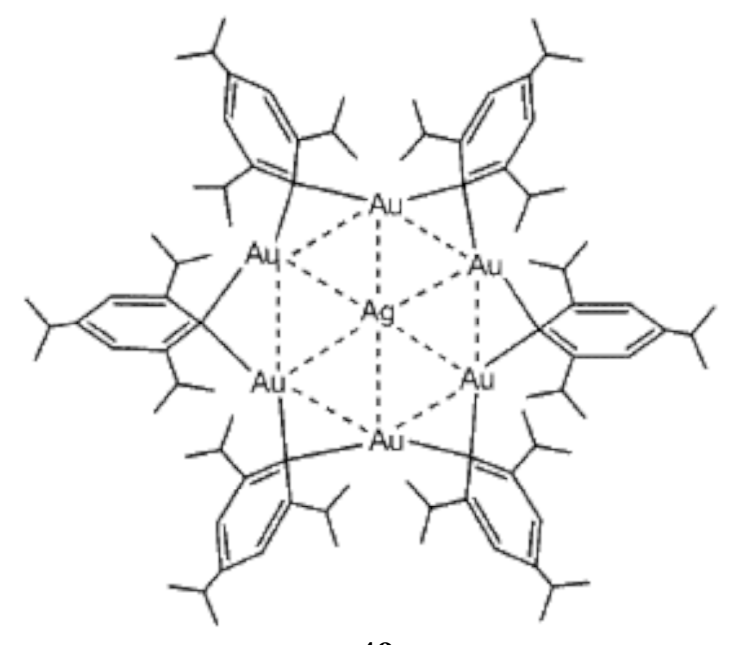

49

(Reprinted with permission from ref. 154.

Copyright Royal Society of Chemistry)

In the large $\mathrm{Ag}-\mathrm{Au}$ alkynyl-diphosphine aggregate $\left[\mathrm{Ag}_{4} \mathrm{Au}_{14}\left(\mathrm{C}_{2} \mathrm{Ph}\right)_{12}(P P)_{6}\right]\left[\mathrm{PF}_{6}\right]_{4}$, which can serve as a phosphorescence dye suited for one- and two-photon imaging in human stem cells, the Ag-Au distances are in the range 2.8535(7)-3.0504(7) $\AA^{126}$ 


\section{Intramolecular metallophilic interactions in heterometallic clusters involving metals other than from group 11.}

Because of their relevance and structural analogy with some of the complexes discussed above, we will briefly examine the situation in heterometallic complexes involving closed shell atoms outside group 11 elements. The heterotrinuclear metal-metal bonded chain complex $\left[\mathrm{Hg}\left\{\mathrm{Fe}\left[\mathrm{Si}(\mathrm{OMe})_{3}\right](\mathrm{CO})_{3}(\mathrm{dppm}-P)\right\}_{2}\right]\left(\mathrm{dppm}=\mathrm{Ph}_{2} \mathrm{PCH}_{2} \mathrm{PPh}_{2}\right)^{155-157}$ behaves like a trimetallodiphosphine and chelates a $\mathrm{d}^{10} \mathrm{Cu}(\mathrm{I})$ centre through its $\mathrm{P}$ donors. The resulting complex $\left[\mathrm{Hg}\left\{\mathrm{Fe}\left[\mathrm{Si}(\mathrm{OMe})_{3}\right](\mathrm{CO})_{3}(\mu \text {-dppm })\right\}_{2} \mathrm{Cu}\right]^{+}$(50) has a $\mathrm{T}$-shape geometry and the existence of a $\mathrm{d}^{10}-\mathrm{d}^{10}$ interaction between $\mathrm{Cu}(\mathrm{I})$ and $\mathrm{Hg}(\mathrm{II})$ is supported by the distance of 2.689(2) $\AA$ between them and by theoretical calculations. ${ }^{158}$ An intramolecular dynamic behaviour was evidenced by VT-NMR spectroscopy and explained by an oscillation of the P$\mathrm{Cu}-\mathrm{P}$ unit about the $\mathrm{Cu}(\mathrm{I})-\mathrm{Hg}(\mathrm{II})$ axis.

Although the resulting complexes were not cluster compounds, it is interesting to note that metallomacrocycles containing basic nitrogen atoms and Lewis acidic mercury centres have been used to produce complexes featuring $\mathrm{Cu}(\mathrm{I})-\mathrm{Hg}(\mathrm{II})$ interactions (2.921 and 2.919 $\AA)^{159}$ and $\operatorname{Hg}(\mathrm{II})-\mathrm{Pd}(\mathrm{II}) \quad(3.1020(3)$ and $3.2337(3) \AA)$ interactions. $^{160}$ Metallophilic interactions between $\mathrm{Au}(\mathrm{I})$ and $\mathrm{Hg}(\mathrm{II})$ have been shown to quench the fluorescence of $\mathrm{Au}$ nanoclusters and this has been applied to the highly selective and sensitive detection of mercuric ions. ${ }^{161}$

Reaction of the Fe-Hg-Fe chain complex $\left[\mathrm{Hg}\left\{\mathrm{Fe}\left[\mathrm{Si}(\mathrm{OMe})_{3}\right](\mathrm{CO})_{3}(\mathrm{dppm}-P)\right\}_{2}\right]$ mentioned above with a $\mathrm{d}^{10} \operatorname{Pd}(0)$ precursor afforded the related complex $\left[\mathrm{Hg}\left\{\mathrm{Fe}\left[\mathrm{Si}(\mathrm{OMe})_{3}\right](\mathrm{CO})_{3}(\mu \text {-dppm })\right\}_{2} \mathrm{Pd}\right]$ (51) in which a $\mathrm{Pd}-\mathrm{Hg}$ bond has formed $(2.6915(8)$ $\AA$ ). It is no longer orthogonal to the $\mathrm{Fe}-\mathrm{Hg}-\mathrm{Fe}$ axis, as in the case of the related $\mathrm{Cu}-\mathrm{HgFe}_{2}$ complex, because of a favourable interaction of the Pd centre with a Fe-bound carbonyl ligand. ${ }^{156}$ The Pd-Hg bond length is shorter than is complexes showing Pd-Hg d ${ }^{8}-\mathrm{d}^{10}$ contacts (2.8797(8)-3.2841(2) A). ${ }^{162-166}$ This complex also undergoes dynamic behaviour in solution, but this time the motion involves a sliding of the Pd centre along the Fe-Hg-Fe chain. Changing the reagent opposed to the chain complex $\left[\mathrm{Hg}\left\{\mathrm{Fe}\left[\mathrm{Si}(\mathrm{OMe})_{3}\right](\mathrm{CO})_{3}(\mathrm{dppm}-P)\right\}_{2}\right]$ for another $\mathrm{d}^{10}$ fragment, this time a $\operatorname{Pt}(0)$ centre, afforded with $\mathbf{5 2}$ yet another type of complex. ${ }^{157}$ Although in $\mathbf{5 2}$ a triangular Fe-Hg-Pt unit is present, with a Pt-Hg distance of 2.824(1) A, a intramolecular redox reaction has taken place and a trimethoxysilyl group originally bound to $\mathrm{Fe}$ has migrated to platinum, a rare event. ${ }^{167-171}$ The possibility of reversible isomerization involving the Pt analog of $\mathbf{5 1}$ has been discussed. ${ }^{157}$ 


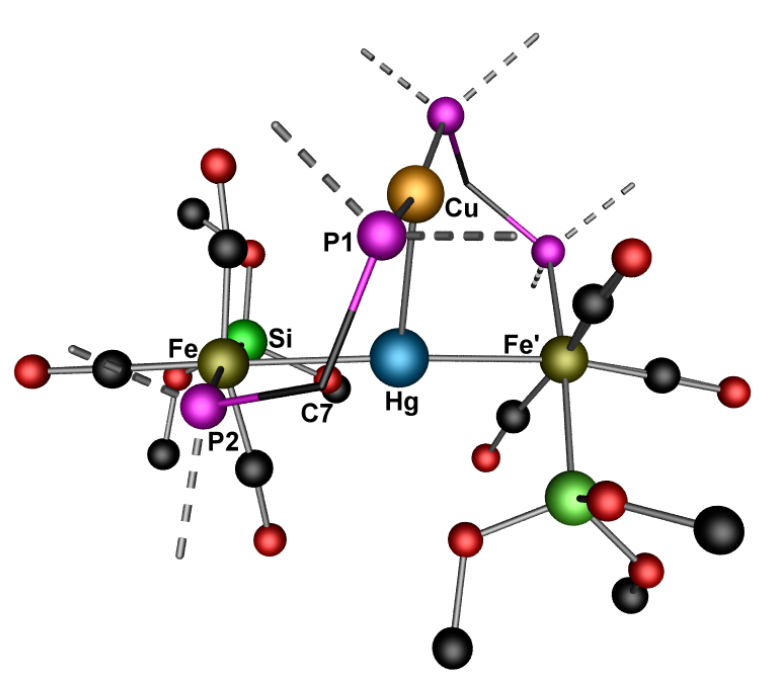

50

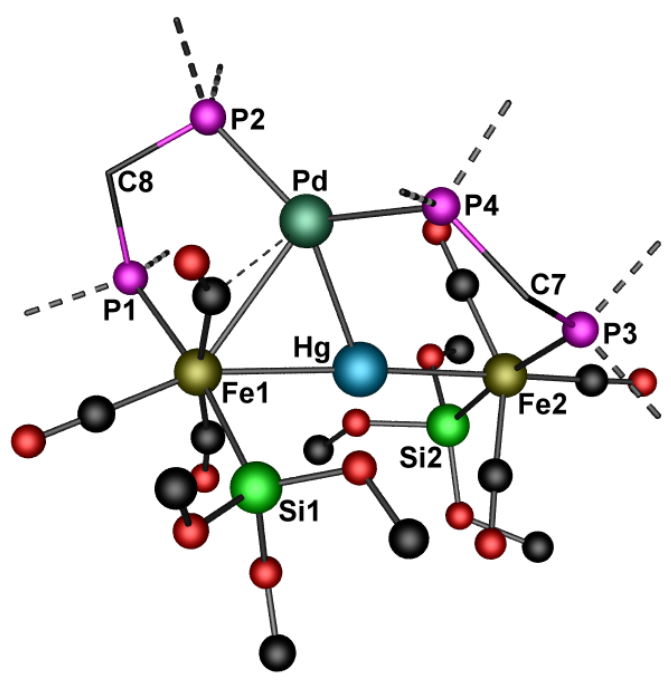

51

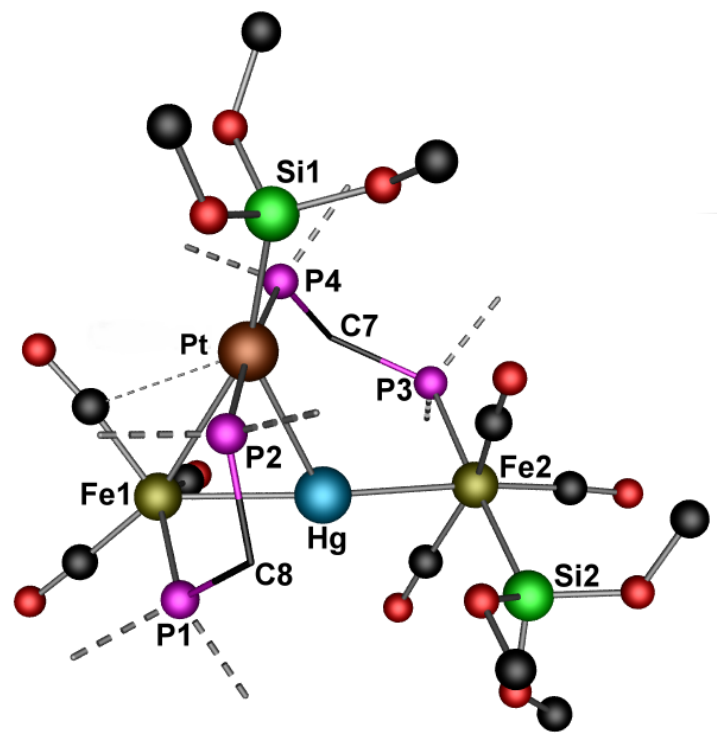

52

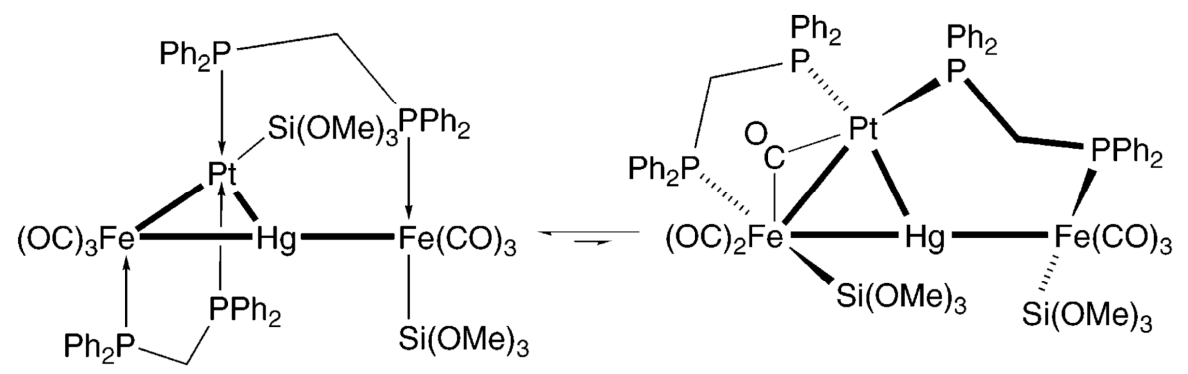

View of the structure of $\mathbf{5 2}$ and suggested reversible isomerization of the complex (shift of the $-\mathrm{Si}(\mathrm{OMe})_{3}$ group between $\mathrm{Pt}$ and $\left.\mathrm{Fe}\right){ }^{157}$ 
In the $v_{2}$-square cluster $\left[\left(\eta^{5}-\mathrm{CH}_{3} \mathrm{C}_{5} \mathrm{H}_{4}\right) \mathrm{Mn}(\mathrm{CO})_{2} \mathrm{Hg}\right](\mathbf{5 3})$, the $\mathrm{Hg}$ - $\mathrm{Hg}$ distances of 2.888(2) $\AA$ and the non-linearity of the $\mathrm{Mn}-\mathrm{Hg}-\mathrm{Mn}$ unit $\left(157.2^{\circ}\right)$ are indicative of $\mathrm{Hg}-\mathrm{Hg}$ interactions. ${ }^{172}$ For comparison, a value of $1.75(7) \AA$ has been calculated for the van der Waals radius of $\mathrm{Hg}(\mathrm{II}),{ }^{173}$ in good agreement with the value of $1.73 \AA$ obtained experimentally for $\mathrm{Hg}(\mathrm{II})$ in $\left[\mathrm{HgR}_{2}\right]_{2} \cdot{ }^{174}$ The structure of $\left[\mathrm{CdFe}(\mathrm{CO})_{4}\right]_{4} \cdot 2$ acetone (54) is also that of a $v_{2}$-square cluster and consists of a nearly planar, centrosymmetric, eight-membered ring of alternating $\mathrm{Cd}$ and cis- $\mathrm{Fe}(\mathrm{CO})_{4}$ units. ${ }^{175}$ Its core geometry is strongly distorted because of the coordination of acetone molecules to two $\mathrm{Cd}$ atoms but no $\mathrm{Cd}-\mathrm{Cd}$ interactions were observed, the distance between these atoms being in the range 3.55-3.60 $\AA$. These examples show that although this type of $v_{2}$-square geometry is favourable for metal-metal interactions within the central square, these do not always take place.

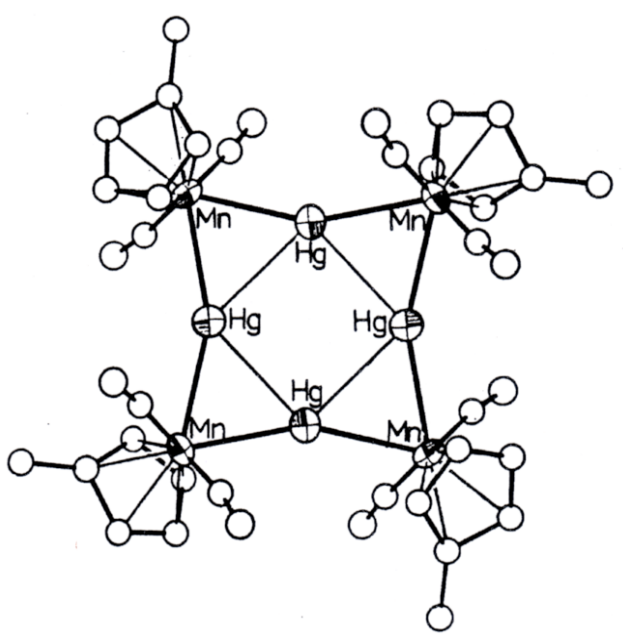

53

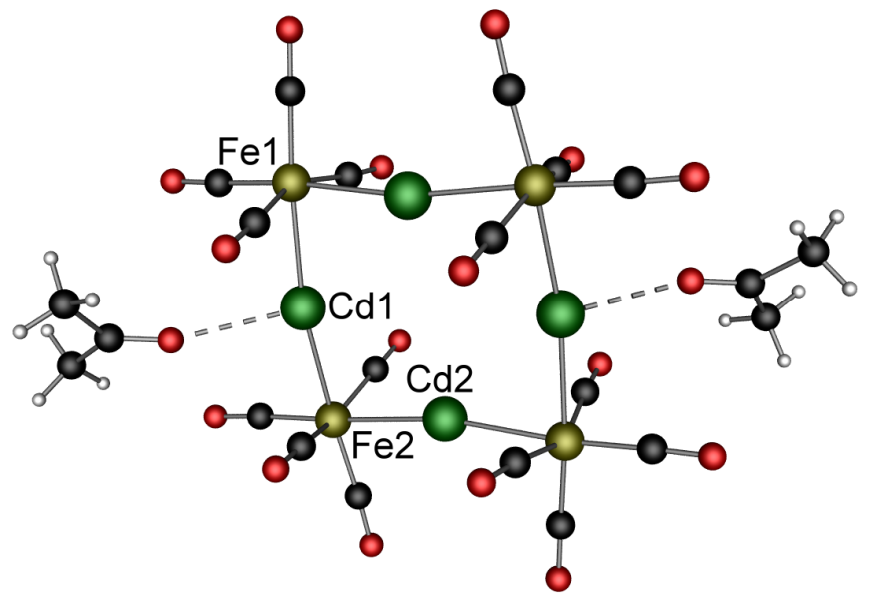

54

(Reproduced with permission from ref. 172.

Copyright Wiley-VCH Verlag GmbH \& Co. KGaA)

The $v_{2}$-triangular cluster complex $\left[\operatorname{Ir}_{3} \mathrm{Pt}_{3}(\mu-\mathrm{CO})_{3}(\mathrm{CO})_{3}\left(\eta-\mathrm{C}_{5} \mathrm{Me}_{5}\right)_{3}\right](\mathbf{5 5})$ was obtained in quantitative yield by reaction of $\left[\operatorname{Ir}(\mathrm{CO})_{2}\left(\eta-\mathrm{C}_{5} \mathrm{Me}_{5}\right)_{3}\right]$ with the $\mathrm{Pt}(0)$ precursor $\left[\mathrm{Pt}\left(\mathrm{C}_{2} \mathrm{H}_{4}\right)_{3}\right]$ in diethylether at $0{ }^{\circ} \mathrm{C} .{ }^{176}$ It contains a nearly planar array of metal atoms, with a central triangle of platinum atoms (mean Pt-Pt distance of 2.703(3) $\AA$ ), whose edges are bridged by an iridium fragment. The iridium atoms each carry a $\eta-\mathrm{C}_{5} \mathrm{Me}_{5}$ ligand and are coordinated by two $\mathrm{CO}$ ligands. The $\mathrm{Ir}_{3} \mathrm{Pt}_{3}(\mu-\mathrm{CO})$ unit has approximate $C_{3}$-symmetry. The centroids of the $\eta-\mathrm{C}_{5} \mathrm{Me}_{5}$ ligands are well out of the $\mathrm{Ir}_{3} \mathrm{Pt}_{3}$ plane, one above and two below this plane. Although the Ir-Pt interactions are not of the $\mathrm{d}^{10}-\mathrm{d}^{10}$ type, the $v_{2}$-triangular structure of this cluster is strikingly similar to those of clusters involving $\mathrm{d}^{10}$ ions of the group 11 metals discussed above. 


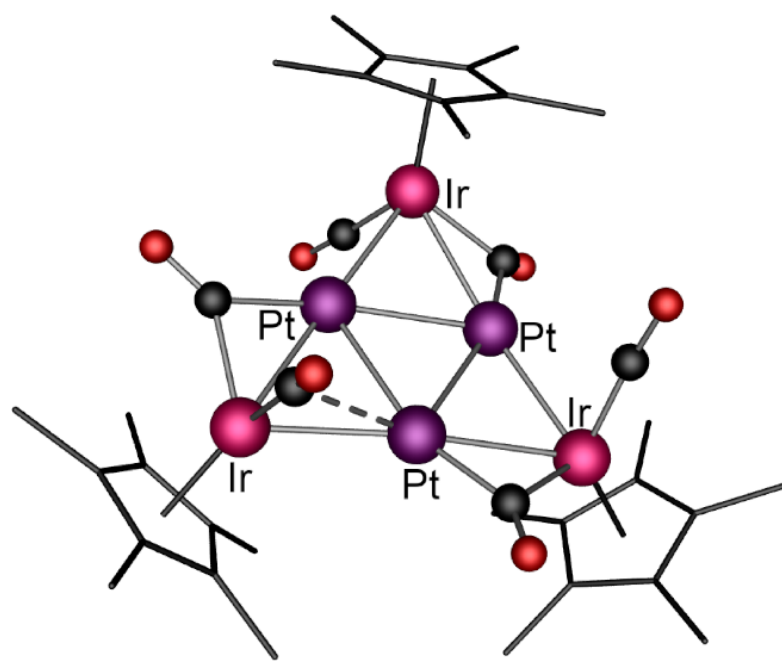

55

\section{Conclusions}

The number of metal complexes and clusters in which metallophilic interactions contribute significantly to their structure and properties is now very large and continues to grow. Even when considering only interactions involving the $\mathrm{d}^{10}$ ions from the group 11 metals, in order to facilitate comparisons, it is clear that their occurrence is possible in a number of structural types, although some arrangements of the metal cores seem to occur more frequently. We have focused here on heterometallic clusters of the transition metals, whose diversity is of course much larger than that of the homometallic ones, which allows an even larger scope for metallophilic interactions. Whereas unsupported $\mathrm{d}^{10}-\mathrm{d}^{10}$ interactions may only represent $c a$. 7-11 kcal/mol, recognizing their importance allows for a better understanding of the structural and physical properties of complex molecules. An evaluation of the energetics involved is difficult in metal clusters where bridging metal atoms and ligands enforce certain structural geometries and this prevents an easy separation of the various energetic contributions. Qualitative structural elements are often suggestive of the occurrence of metallophilic interactions, such as metal-metal distance and/or bond angles. Thus for example, attractive $\mathrm{d}^{10}-\mathrm{d}^{10}$ interactions appear responsible for the inward bending of the MoAg-Mo or Mo-Au-Mo sequences in the "square-in-a-square" octanuclear clusters ( $v_{2}$-square structures) 17, 18, 29 and 30. The values of the separations between the $\mathrm{d}^{10}$ ions involved represents a major indicator of the occurrence of attractive metallophilic interactions, and these values can be compared to the sum of the van der Waals radii, and are sometimes even shorter than the sum of the covalent radii. Table 1 provides structural informations from the literature for benchmarking purposes. 
Table 1. Covalent, atomic metal and van der Waals radii for the group 11 metals (in $\AA$ )

\begin{tabular}{|c|c|c|c|}
\hline & $\mathrm{M}=\mathrm{Cu}$ & $\mathrm{M}=\mathrm{Ag}$ & $\mathrm{M}=\mathrm{Au}$ \\
\hline $2 \times$ covalent radius (mono-coordinated univalent $\mathrm{M})^{61}$ & 2.24 & 2.56 & 2.48 \\
\hline $2 \times$ covalent radius (two-coordinated univalent $M)^{71,177}$ & 2.26 & 2.66 & 2.50 \\
\hline $2 \times$ covalent radius (four-co-ordinated univalent $M)^{177}$ & 2.58 & 2.92 & 2.74 \\
\hline $2 \times$ single bond metallic radius ${ }^{35}$ & 2.346 & 2.678 & 2.672 \\
\hline $2 \times$ metal atom radius ${ }^{98}$ & 2.556 & 2.89 & 2.884 \\
\hline $2 \times$ covalent radius $^{99}$ & $2.64(4)$ & $2.90(5)$ & $2.72(6)$ \\
\hline $2 \mathrm{x}$ van der Waals radius ${ }^{34}$ & 2.80 & 3.44 & 3.32 \\
\hline
\end{tabular}

The difficulties associated with a detailed theoretical analysis of the metallophilic interactions are that not only must relativistic basis sets be used but the energy surfaces are rather shallow. We are currently trying to assess the role of the metallophilic interactions in the family of clusters $\left[\mathrm{M}\left\{\mathrm{MoCp}(\mathrm{CO})_{3}\right\}\right]_{\mathrm{n}}{ }^{\mathrm{n}-}(\mathrm{n}=3$ for $\mathrm{M}=\mathrm{Cu} ; \mathrm{n}=4$ for $\mathrm{M}=\mathrm{Ag}, \mathrm{Au})$ where the $\mathrm{Cu}_{3} \mathrm{Mo}_{3}$ clusters 6 and 7 have a $v_{2}$-triangular structure, in contrast to the $v_{2}$-square geometry of the $\mathrm{Ag}_{4} \mathrm{Mo}_{4}$ and $\mathrm{Au}_{4} \mathrm{Mo}_{4}$ clusters 17, 18 and 29, 30, respectively.

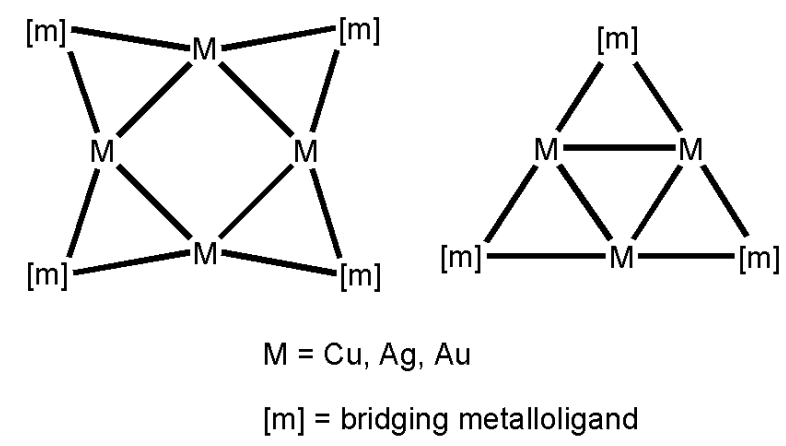

In related clusters, square metal cores have been encountered in this review with $\mathrm{Cu}(\mathrm{I})$ and triangular arrays with $\mathrm{Ag}(\mathrm{I})$ and $\mathrm{Au}(\mathrm{I})$ ! Of course, steric factors should not be overlooked, and are often difficult to quantify. An additional challenge is to prepare and characterize polymetallic clusters containing two or more chemically different $\mathrm{d}^{10}$ metal ions. Will their geometry and properties be directly related to that of clusters containing only one type of $\mathrm{d}^{10}$ ion or not and if yes, which of the $\mathrm{d}^{10}$ ion will influence most the structure and properties. In complexes containing mixed $\mathrm{d}^{10}$ ions interacting with each other, a shortened separation compared to analogous complexes containing only one type of $\mathrm{d}^{10}$ ion has often been noted. It has been attributed to the introduction of attractive Coulomb interactions between the 
dissimilar metals which increase the dispersion forces. ${ }^{178,179}$ Such interactions have also been invoked to explain the stability and shortened intermetallic separations in the chain complexes $\operatorname{Pd}(0)-\mathrm{Tl}(\mathrm{I})-\mathrm{Au}(\mathrm{I})$ and $\operatorname{Pt}(0)-\mathrm{Tl}(\mathrm{I})-\mathrm{Au}(\mathrm{I})$ which were the first to involve three different closed-shell metals. ${ }^{180}$ Over the last few years, it has been increasingly observed that heterometallic $\mathrm{d}^{10}-\mathrm{d}^{10}$ interactions can bring about new photophysical properties and more examples will certainly emerge of unique behaviour for such polymetallic assemblies. $^{66,74,77-79,85,111,126-138,143,181-188}$

Acknowledgment. We are grateful to the referees for their comments, to Dr. Roberto Pattacini for assistance, and to the CNRS, the Ministère de l'Enseignement Supérieur et de la Recherche, the DFH/UFA, the DFG International Research Training Group GRK532 and the Agence Nationale de la Recherche (ANR-06-BLAN-410) for support of our own research in this field. 


\section{References}

J. A. Bertrand, F. A. Cotton and W. A. Dollase, J. Am. Chem. Soc., 1963, 85, 1349.

F. A. Cotton, Inorg. Chem., 1964, 3, 1217.

F. A. Cotton, Quart. Rev., 1966, 20, 389.

K. Wade, J. Chem. Soc. D., 1971, 792.

K. Wade, Adv. Inorg. Chem. Radiochem., 1976, 18, 1.

D. M. P. Mingos, Acc. Chem. Res., 1984, 17, 311.

D. F. Shriver, H. D. Kaesz and R. D. Adams, The chemistry of metal cluster complexes, Wiley-VCH, Weinheim, 1990.

D. M. P. Mingos and D. J. Wales, Introduction to Cluster Chemistry, Prentice Hall, 1990.

G. Gonzalez-Moraga, Cluster Chemistry, Springer-Verlag, Berlin, 1993.

G. Schmid, Clusters and Colloids. From Theory to Applications, Wiley-VCH, Weinheim, 1994.

L. J. de Jongh, Physics and Chemistry of Metal Cluster Compounds. Model Systems for Small Metal Particles, Kluwer Academic, Dordrecht, 1994.

U. Kreibig and M. Vollmer, Optical properties of metal clusters, Springer, 1995.

S. M. Kauzlarich, Chemistry, structure, and bonding of Zintl phases and ions, WileyVCH, Weinheim, 1996.

D. M. P. Mingos, Structural and electronic paradigms in cluster chemistry, SpringerVerlag, 1997.

R. D. Adams and F. A. Cotton, Catalysis by Di-and Polynuclear Metal Cluster Complexes, Wiley-VCH, Weinheim (Germany), 1998.

H. Schmidbaur, Gold: Progress in Chemistry, Biochemistry and Technology, Wiley, Chichester, 1999.

P. Braunstein, L. A. Oro and P. R. Raithby, Metal Clusters in Chemistry, Wiley-VCH, Weinheim, 1999.

P. J. Dyson and J. S. McIndoe, Transition metal carbonyl cluster chemistry, Gordon and Breach Science Publishers, 2000.

D. L. Feldheim and J. C. A. Foss, Metal Nanoparticles, Marcel Dekker, Inc., New York, 2002.

M. Driess and H. Nöth, Molecular clusters of the main group elements, Wiley-VCH, Weinheim, 2004.

T. P. Fehlner, J.-F. Halet and J.-Y. Saillard, Molecular clusters: a bridge to solidstate chemistry, Cambridge University Press, Cambridge, 2007.

P. Braunstein and J. Rosé, in Metal Clusters in Chemistry, eds. P. Braunstein, L. A. Oro and P. R. Raithby, Wiley-VCH, Weinheim, 1999, vol. 2, pp. 616.

C. E. Coffey, J. Lewis and R. S. Nyholm, J. Chem. Soc., 1964, 1741.

J. W. Lauher and K. Wald, J. Am. Chem. Soc., 1981, 103, 7648.

P. Braunstein, J. Rosé, Y. Dusausoy and J.-P. Mangeot, C. R. Acad. Sci., Ser. IIc: Chim., 1982, 294, 967.

X. Li, B. Kiran and L.-S. Wang, J. Phys. Chem. A, 2005, 109, 4366.

R. Hoffmann, Angew. Chem., Int. Ed. Engl., 1982, 21, 711.

D. M. P. Mingos, Gold Bull., 1984, 17, 5.

P. Braunstein and J. Rosé, Gold Bull., 1985, 18, 17.

B. R. Theobald, P. C. Minshall and D. M. P. Mingos, unpublished, quoted in D. M. P. Mingos, Pure Appl. Chem. 1980, 52, 705.

P. Braunstein, H. Lehner, D. Matt, A. Tiripicchio and M. Tiripicchio-Camellini, Angew. Chem. Int. Ed. Engl., 1984, 23, 304. 
R. Galassi, R. Poli, E. A. Quadrelli and J. C. Fettinger, Inorg. Chem., 1997, 36, 3001. P. Braunstein, G. E. Herberich, M. Neuschütz, M. U. Schmidt, U. Englert, P. Lecante and A. Mosset, Organometallics, 1998, 17, 2177.

A. Bondi, J. Phys. Chem., 1964, 68, 441.

L. Pauling, The Nature of the Chemical Bond, 3rd Ed., Cornell Univ. Press, Ithaca, NY, 1960.

J. Muñiz, C. Wang and P. Pyykkö, Chem. Eur. J., 2010, in press.

F. Scherbaum, A. Grohmann, B. Huber, C. Krüger and H. Schmidbaur, Angew. Chem. Int. Ed. Engl., 1988, 27, 1544.

H. Schmidbaur, Gold Bull., 1990, 23, 11.

H. Schmidbaur, Chem. Soc. Rev., 1995, 24, 391.

H. Schmidbaur, F. Gabbaie, A. Schier and J. Riede, Organometallics, 1995, 14, 4969.

H. Schmidbaur, Gold Bull., 2000, 33, 3.

H. Schmidbaur and A. Schier, Chem. Soc. Rev., 2008, 37, 1931.

P. K. Mehrotra and R. Hoffmann, Inorg. Chem., 1978, 17, 2187.

M. Jansen, J. Less Common Met., 1980, 76, 285.

M. Jansen, Angew. Chem. Int. Ed. Engl., 1987, 26, 1098.

A. Görling, N. Rösch, D. E. Ellis and H. Schmidbaur, Inorg. Chem., 1991, 30, 3986.

J. Li and P. Pyykkö, Chem. Phys. Lett., 1992, 197, 586.

P. Pyykkö, J. Li and N. Runeberg, Chem. Phys. Lett., 1994, 218, 133.

M. J. Katz, K. Sakai and D. B. Leznoff, Chem. Soc. Rev., 2008, 37, 1884.

P. Pyykkö and J.-P. Desclaux, Acc. Chem. Res., 1979, 12, 276.

N. Kaltsoyannis, J. Chem. Soc., Dalton Trans., 1996, 1.

P. Pyykkö and F. Mendizabal, Chem. Eur. J., 1997, 3, 1458.

P. Pyykkö, Angew. Chem., Int. Ed., 2002, 41, 3573.

S.-G. Wang and W. H. E. Schwarz, J. Am. Chem. Soc., 2004, 126, 1266.

M. A. Carvajal, S. Alvarez and J. J. Novoa, Chem. Eur. J., 2004, 10, 2117.

P. Pyykkö, Angew. Chem., Int. Ed., 2004, 43, 4412.

H. Schmidbaur, S. Cronje, B. Djordjevic and O. Schuster, Chem. Phys., 2005, 311, 151.

P. Pyykkö, Inorg. Chim. Acta, 2005, 358, 4113.

W. Q. Tian, M. Ge, F. Gu, T. Yamada and Y. Aoki, J. Phys. Chem. A, 2006, 110, 6285.

P. Pyykkö, Chem. Soc. Rev., 2008, 37, 1967.

P. Pyykkö and M. Atsumi, Chem. Eur. J., 2009, 15, 186.

S. Sculfort, P. Croizat, A. Messaoudi, M. Bénard, M.-M. Rohmer, R. Welter and P. Braunstein, Angew. Chem. Int. Ed., 2009, 48, 9663.

P. Schwerdtfeger and M. Lein, in Gold Chemistry: Applications and Future Directions in the Life Sciences, ed. F. Mohr, Wiley-VCH, Weinheim, 2009.

E. O'Grady and N. Kaltsoyannis, Phys. Chem. Chem. Phys., 2004, 6, 680.

G. J. Hutchings, M. Brust and H. Schmidbaur, Chem. Soc. Rev., 2008, 37, 1759.

L. H. Doerrer, Comments Inorg. Chem., 2008, 29, 93

L. H. Doerrer, Dalton Trans., 2010, 39, 3543.

J.-M. Poblet and M. Bénard, Chem. Commun., 1998, 1179.

M. A. Carvajal, J. J. Novoa and S. Alvarez, J. Am. Chem. Soc., 2004, 126, 1465.

J. Grundy, B. Donnadieu and F. Mathey, J. Am. Chem. Soc., 2006, 128, 7716.

A. Bayler, A. Schier, G. A. Bowmaker and H. Schmidbaur, J. Am. Chem. Soc., 1996, 118, 7006.

X.-L. Zhao and T. C. W. Mak, Dalton Trans., 2004, 3212.

B. Liu, W. Chen and S. Jin, Organometallics, 2007, 26, 3660.

Z.-N. Chen, N. Zhao, Y. Fan and J. Ni, Coord. Chem. Rev., 2009, 253, 1. 
M. C. Gimeno, in Modern Supramolecular Gold Chemistry: Gold-Metal Interactions and Applications., ed. A. Laguna, Wiley-VCH, Weinheim, 2008, pp. 1.

A. Laguna, Modern Supramolecular Gold Chemistry: Gold-Metal Interactions and Applications, Wiley-VCH, Weinheim, 2008.

A. Barbieri, G. Accorsi and N. Armaroli, Chem. Commun., 2008, 2185.

E. J. Fernandez, A. Laguna and J. M. Lopez-de-Luzuriaga, Dalton Trans., 2007, 1969.

D. L. Phillips, C.-M. Che, K. H. Leung, Z. Mao and M.-C. Tse, Coord. Chem. Rev., 2005, 249, 1476.

C.-M. Che and S.-W. Lai, Coord. Chem. Rev., 2005, 249, 1296.

H. Fleischer, Coord. Chem. Rev., 2005, 249, 799.

J. H. K. Yip, J. Wu, K.-Y. Wong, K. P. Ho, C. S.-N. Pun and J. J. Vittal, J. Chin. Chem. Soc., 2004, 51, 1245.

H. Müller-Buschbaum, Z. Anorg. Allg. Chem., 2004, 630, 2125.

V. J. Catalano, B. L. Bennett, M. A. Malwitz, R. L. Yson, H. M. Kar, S. Muratidis and S. J. Horner, Comments Inorg. Chem., 2003, 24, 39.

M. Bardaji and A. Laguna, Eur. J. Inorg. Chem., 2003, 3069.

V. W.-W. Yam, Acc. Chem. Res., 2002, 35, 555.

T. Tanase, Bull. Chem. Soc. Jpn., 2002, 75, 1407.

L. H. Gade, Angew. Chem., Int. Ed., 2001, 40, 3573.

A. Vegas, Crystallogr. Rev., 2000, 7, 189.

L. F. Rhodes, J. C. Huffman and K. G. Caulton, J. Am. Chem. Soc., 1983, 105, 5137.

L. F. Rhodes, J. C. Huffman and K. G. Caulton, J. Am. Chem. Soc., 1985, 107, 1759.

G. Doyle, B. T. Heaton and E. Occhiello, Organometallics, 1985, 4, 1224.

G. Doyle, K. A. Eriksen and D. Van Engen, J. Am. Chem. Soc., 1986, 108, 445.

T. H. Lemmen, J. C. Huffman and K. G. Caulton, Angew. Chem., Int. Ed. Engl., 1986, 25, 262.

P. Klüfers, Angew. Chem., Int. Ed. Engl., 1984, 23, 307.

S. Sculfort, PhD Thesis, Université de Strasbourg, 2009.

G. Doyle, K. A. Eriksen and D. Van Engen, Organometallics, 1985, 4, 2201.

E. Wiberg, A. F. Holleman and N. Wiberg, Lehrbuch der Anorganischen Chemie, 102. Auflage, W. de Gruyter, Berlin (Germany), 2007.

B. Cordero, V. Gomez, A. E. Platero-Prats, M. Revés, J. Echeverria, E. Cremades, F. Barragan and S. Alvarez, Dalton Trans., 2008, 2832.

Q. Huang, X. Wu, Q. Wang, T. Sheng and J. Lu, Inorg. Chem., 1996, 35, 893.

M. Hakansson, H. Eriksson, A. Berglund Ahman and S. Jagner, J. Organomet. Chem., 2000, 595, 102.

A. Vega, V. Calvo, E. Spodine, A. Zarate, V. Fuenzalida and J.-Y. Saillard, Inorg. Chem., 2002, 41, 3389.

M.-E. Moret and P. Chen, J. Am. Chem. Soc., 2009, 131, 5675.

E. J. Fernandez, A. Laguna, J. M. Lopez-de-Luzuriaga, M. Monge, M. Montiel, M. E. Olmos, J. Perez, R. C. Puelles and J. C. Saenz, Dalton Trans., 2005, 1162.

J. Ott and L. M. Venanzi, J. Am. Chem. Soc., 1985, 107, 1760.

F. Calderazzo, G. Pampaloni, U. Englert and J. Strähle, Angew. Chem., Int. Ed. Engl., 1989, 28, 471.

P. Klüfers, Z. Kristallogr., 1984, 166, 143.

V. G. Albano, F. Azzaroni, M. C. Iapalucci, G. Longoni, M. Monari, S. Mulley, D. M. Proserpio and A. Sironi, Inorg. Chem., 1994, 33, 5320.

V. G. Albano, M. Carmela Iapalucci, G. Longoni, M. Monari, A. Paselli and S. Zacchini, Organometallics, 1998, 17, 4438.

J.-P. Lang and K. Tatsumi, Inorg. Chem., 1999, 38, 1364. 
111 V. J. Catalano and A. L. Moore, Inorg. Chem., 2005, 44, 6558.

112 J. E. Ellis, J. Am. Chem. Soc., 1981, 103, 6106.

113 M. A. Alvarez, I. Amor, M. E. Garcia and M. A. Ruiz, Inorg. Chem., 2008, 47, 7963.

114 Q.-M. Wang, Y.-A. Lee, O. Crespo, J. Deaton, C. Tang, H. J. Gysling, M. Concepción Gimeno, C. Larraz, M. D. Villacampa, A. Laguna and R. Eisenberg, $J$. Am. Chem. Soc., 2004, 126, 9488.

115 O. Crespo, M. Concepcion Gimeno, A. Laguna, C. Larraz and M. D. Villacampa, Chem. Eur. J., 2007, 13, 235.

116 A. Antinolo, J. K. Burdett, B. Chaudret, O. Eisenstein, M. Fajardo, F. Jalon, F. Lahoz, J. A. Lopez and A. Otero, J. Chem. Soc., Chem. Commun., 1990, 17.

117 J. Pethe, C. Maichle-Mossmer and J. Strähle, Z. Anorg. Allg. Chem., 1997, 623, 1413.

118 P. Braunstein and R. J. H. Clark, J. Chem. Soc., Dalton Trans., 1973, 1845.

119 S. Sculfort, R. Welter and P. Braunstein, Inorg. Chem., 2010, 49, 2372.

120 T. A. Stromnova, I. N. Busygina, S. B. Katser, A. S. Antsyshkina, M. A. PoraiKoshits and I. I. Moiseev, J. Chem. Soc., Chem. Commun., 1988, 114.

121 R. Della Pergola, L. Garlaschelli, M. C. Malatesta, C. Manassero and M. Manassero, Inorg. Chem., 2006, 45, 8465.

122 V. G. Albano, F. Calderoni, M. C. Iapalucci, G. Longoni and M. Monari, J. Chem. Soc., Chem. Commun., 1995, 433.

123 V. G. Albano, C. Castellari, C. Femoni, M. C. Iapalucci, G. Longoni, M. Monari and S. Zacchini, J. Cluster Sci., 2001, 12, 75.

124 A. A. Mohamed, M. A. Rawashdeh-Omary, M. A. Omary and J. P. Fackler, Jr., Dalton Trans. , 2005, 2597.

125 H. E. Abdou, A. A. Mohamed and J. P. Fackler, Jr., Inorg. Chem., 2007, 46, 141.

126 I. O. Koshevoy, Y.-C. Lin, Y.-C. Chen, A. J. Karttunen, M. Haukka, P.-T. Chou, S. P. Tunik and T. A. Pakkanen, Chem. Commun., 2010, 46, 1440.

127 I. O. Koshevoy, Y.-C. Lin, A. J. Karttunen, P.-T. Chou, P. Vainiotalo, S. P. Tunik, M. Haukka and T. A. Pakkanen, Inorg. Chem., 2009, 48, 2094.

128 V. J. Catalano, A. L. Moore, J. Shearer and J. Kim, Inorg. Chem., 2009, 48, 11362.

129 D. Rios, M. M. Olmstead and A. L. Balch, 2009, 48, 5279.

130 I. O. Koshevoy, A. J. Karttunen, S. P. Tunik, M. Haukka, S. I. Selivanov, A. S. Melnikov, P. Y. Serdobintsev, M. A. Khodorkovskiy and T. A. Pakkanen, Inorg. Chem., 2008, 47, 9478.

131 E. J. Fernandez, P. G. Jones, A. Laguna, J. M. Lopez-de-Luzuriaga, M. Monge, M. E. Olmos and R. C. Puelles, Organometallics, 2007, 26, 5931.

132 V. J. Catalano and A. O. Etogo, Inorg. Chem., 2007, 46, 5608.

133 E. J. Fernandez, A. Laguna, J. M. Lopez-de-Luzuriaga, M. Montiel, M. E. Olmos, J. Perez and R. C. Puelles, Organometallics, 2006, 25, 4307.

134 E. J. Fernandez, A. Laguna, J. M. Lopez-de-Luzuriaga, M. Monge, M. Montiel and M. E. Olmos, Inorg. Chem., 2005, 44, 1163.

135 V. J. Catalano, M. A. Malwitz and A. O. Etogo, Inorg. Chem., 2004, 43, 5714.

136 E. J. Fernandez, A. Laguna, J. M. Lopez-De-Luzuriaga, M. Monge, P. Pyykko and N. Runeberg, Eur. J. Inorg. Chem., 2002, 750.

137 E. J. Fernandez, J. M. Lopez-De-Luzuriaga, M. Monge, M. A. Rodriguez, O. Crespo, M. C. Gimeno, A. Laguna and P. G. Jones, Chem.-Eur. J., 2000, 6, 636.

138 E. J. Fernandez, M. C. Gimeno, A. Laguna, J. M. Lopez-de-Luzuriaga, M. Monge, P. Pyykkö and D. Sundholm, J. Am. Chem. Soc., 2000, 122, 7287.

139 M. J. Freeman, A. G. Orpen and I. D. Salter, J. Chem. Soc., Dalton Trans., 1987, 1001.

140 M. J. Freeman, M. Green, A. G. Orpen, I. D. Salter and F. G. A. Stone, J. Chem. Soc., Chem. Commun., 1983, 1332. 
141 O. Crespo, E. J. Fernandez, M. Gil, M. Concepcion Gimeno, P. G. Jones, A. Laguna, J. M. Lopez-de-Luzuriaga and M. E. Olmos, J. Chem. Soc., Dalton Trans., 2002, 1319.

142 R. Pattacini, L. Barbieri, A. Stercoli, D. Cauzzi, C. Graiff, M. Lanfranchi, A. Tiripicchio and L. Elviri, J. Am. Chem. Soc., 2006, 128, 866.

143 I. O. Koshevoy, L. Koskinen, M. Haukka, S. P. Tunik, P. Y. Serdobintsev, A. S. Melnikov and T. A. Pakkanen, Angew. Chem., Int. Ed., 2008, 47, 3942.

144 C. E. Strasser and V. J. Catalano, J. Am. Chem. Soc., 2010, 132, 10009.

145 S. S. D. Brown, I. D. Salter and T. Adatia, J. Chem. Soc., Dalton Trans., 1993, 559.

146 I. D. Salter, V. Sik, S. A. Williams and T. Adatia, J. Chem. Soc., Dalton Trans., 1996, 643.

147 H. de la Riva, M. Nieuwhuyzen, C. Mendicute Fierro, P. R. Raithby, L. Male and M. C. Lagunas, Inorg. Chem., 2006, 45, 1418.

148 S.-K. Yip, C.-L. Chan, W. H. Lam, K.-K. Cheung and V. W.-W. Yam, Photochem. Photobiol. Sci. , 2007, 6, 365.

149 M. S. Hussain, M. Ul-Haque and O. M. Abu-Salah, J. Cluster Sci., 1996, 7, 167.

150 I. O. Koshevoy, P. V. Ostrova, A. J. Karttunen, A. S. Melnikov, M. A. Khodorkovskiy, M. Haukka, J. Jänis, S. P. Tunik and T. A. Pakkanen, Dalton Trans., 2010, 39, 9022.

151 H.-J. Haupt, O. Seewald, U. Flörke, V. Buss and T. Weyhermüller, J. Chem. Soc., Dalton Trans., 2001, 3329.

152 O. Schuster, U. Monkowius, H. Schmidbaur, R. S. Ray, S. Krüger and N. Rösch, Organometallics, 2006, 25, 1004.

153 O. M. Abu-Salah, J. Organomet. Chem., 1998, 565, 211.

154 M. Contel, J. Garrido, M. C. Gimeno and M. Laguna, J. Chem. Soc., Dalton Trans., $1998,1083$.

155 P. Braunstein, M. Knorr, A. Tiripicchio and M. Tiripicchio Camellini, Inorg. Chem., 1992, 31, 3685.

156 W. Schuh, P. Braunstein, M. Bénard, M.-M. Rohmer and R. Welter, Angew. Chem. Int. Ed., 2003, 42, 2161.

157 W. Schuh, P. Braunstein, M. Bénard, M.-M. Rohmer and R. Welter, J. Am. Chem. Soc., 2005, 127, 10250.

158 M. Bénard, U. Bodensieck, P. Braunstein, M. Knorr, M. Strampfer and C. Strohmann, Angew. Chem., Int. Ed. Engl., 1997, 36, 2758.

159 U. Patel, H. B. Singh and G. Wolmershäuser, Angew. Chem. Int. Ed., 2005, 44, 1715.

160 S. Sharma, R. S. Baligar, H. B. Singh and R. J. Butcher, Angew. Chem. Int. Ed., 2009, 48, 1987.

161 J. Xie, Y. Zheng and J. Y. Ying, Chem. Comm., 2010, 46, 961.

162 S. Sharma, R. S. Baligar, H. B. Singh and R. J. Butcher, Angew. Chem., Int. Ed. Eng., 2009, 48, 1987.

163 M. A. Bennett, M. Contel, D. C. R. Hockless, L. L. Welling and A. C. Willis, Inorg. Chem., 2002, 41, 844.

164 L. R. Falvello, J. Forniés, A. Martin, R. Navarro, V. Sicilia and P. Villarroya, Inorg. Chem., 1997, 36, 6166.

165 L. R. Falvello, S. Fernandez, R. Navarro and E. P. Urriolabeitia, Inorg. Chem., 1999, 38, 2455.

166 M. Kim, T. J. Taylor and F. P. Gabbai, J. Am. Chem. Soc., 2008, 130, 6332.

167 P. Braunstein, M. Knorr, B. Hirle, G. Reinhard and U. Schubert, Angew. Chem. Int. Ed. Engl., 1992, 31, 1583.

168 M. Knorr, P. Braunstein, A. Tiripicchio and F. Ugozzoli, Organometallics, 1995, 14, 4910 . 
169 P. Braunstein, T. Faure and M. Knorr, Organometallics, 1999, 18, 1791.

170 P. Braunstein, M. Knorr, G. Reinhard, U. Schubert and T. Stährfeldt, Chem. Eur. J., 2000, 6, 4265.

171 A. Messaoudi, P. Deglmann, P. Braunstein and P. Hofmann, Inorg. Chem., 2007, 46, 7899.

172 W. Gäde and E. Weiss, Angew. Chem., Int. Ed. Engl., 1981, 20, 803.

173 P. Pyykkö and M. Straka, Phys. Chem. Chem. Phys., 2000, 2, 2489.

174 A. J. Canty and G. B. Deacon, Inorg. Chim. Acta, 1980, 45, L225.

175 R. D. Ernst, T. J. Marks and J. A. Ibers, J. Am. Chem. Soc., 1977, 99, 2090.

176 M. J. Freeman, A. D. Miles, M. Murray, A. G. Orpen and G. A. Stone, Polyhedron, 1984, 3, 1093.

177 U. M. Tripathi, A. Bauer and H. Schmidbaur, J. Chem. Soc., Dalton Trans., 1997, 2865.

178 N. Runeberg, M. Schütz and H.-J. Werner, J. Chem. Phys., 1999, 110, 7210.

179 F. Mendizabal, P. Pyykkö and N. Runeberg, Chem. Phys. Lett., 2003, 370, 733.

180 V. J. Catalano and M. A. Malwitz, J. Am. Chem. Soc., 2004, 126, 6560.

181 K. Umakoshi, K. Saito, Y. Arikawa, M. Onishi, S. Ishizaka, N. Kitamura, Y. Nakao and S. Sakaki, Chem. Eur. J., 2009, 15, 4238.

182 Q.-H. Wei, G.-Q. Yin, L.-Y. Zhang, L.-X. Shi, Z.-W. Mao and Z.-N. Chen, Inorg. Chem., 2004, 43, 3484.

183 Q.-H. Wei, L.-Y. Zhang, G.-Q. Yin, L.-X. Shi and Z.-N. Chen, J. Am. Chem. Soc., 2004, 126, 9940.

184 V. W.-W. Yam, W.-Y. Lo, C.-H. Lam, W. K.-M. Fung, K. M.-C. Wong, V. C.-Y. Lau and N. Zhu, Coord. Chem. Rev., 2003, 245, 39.

185 M. Yamada and H. Nishihara, Chem. Commun., 2002, 2578.

186 A. Vogler and H. Kunkely, Coord. Chem. Rev., 2001, 219, 489.

187 V. W.-W. Yam, C.-L. Chan, C.-K. Li and K. M.-C. Wong, Coord. Chem. Rev., 2001, 216, 173.

188 V. W.-W. Yam and K. K.-W. Lo, Chem. Soc. Rev., 1999, 28, 323. 